\title{
PELAYANAN PENGADAAN BARANG DAN JASA PUBLIK BERDIMENSI BIAYA TRANSAKSI
}

Dr. Samson Laurens,MT,M.Si
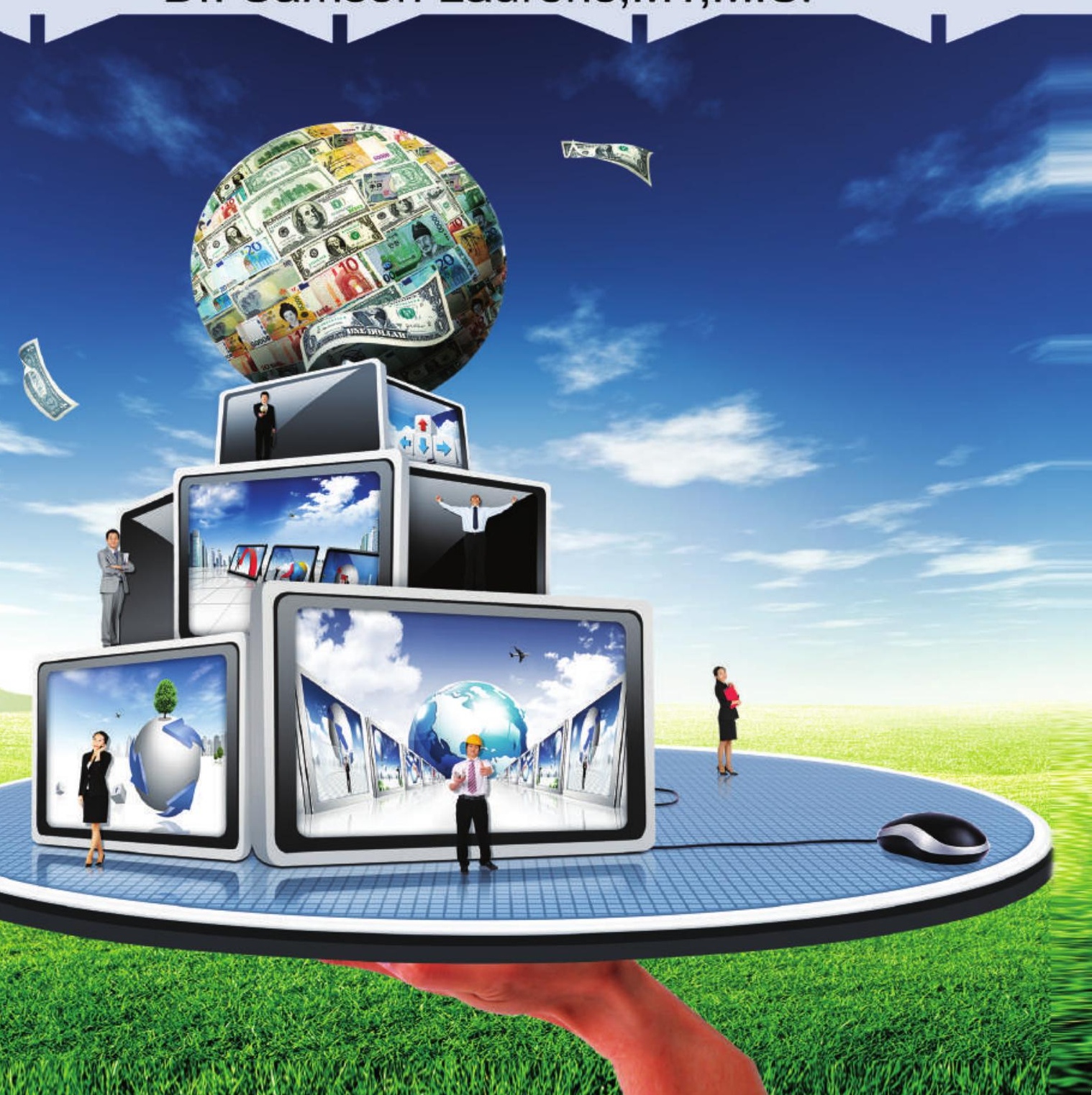


\section{PELAYANAN PENGADAAN BARANG DAN JASA PUBLIK BERDIMENSI BIAYA TRANSAKSI}

Dr. Samson Laurens,MT,M.Si

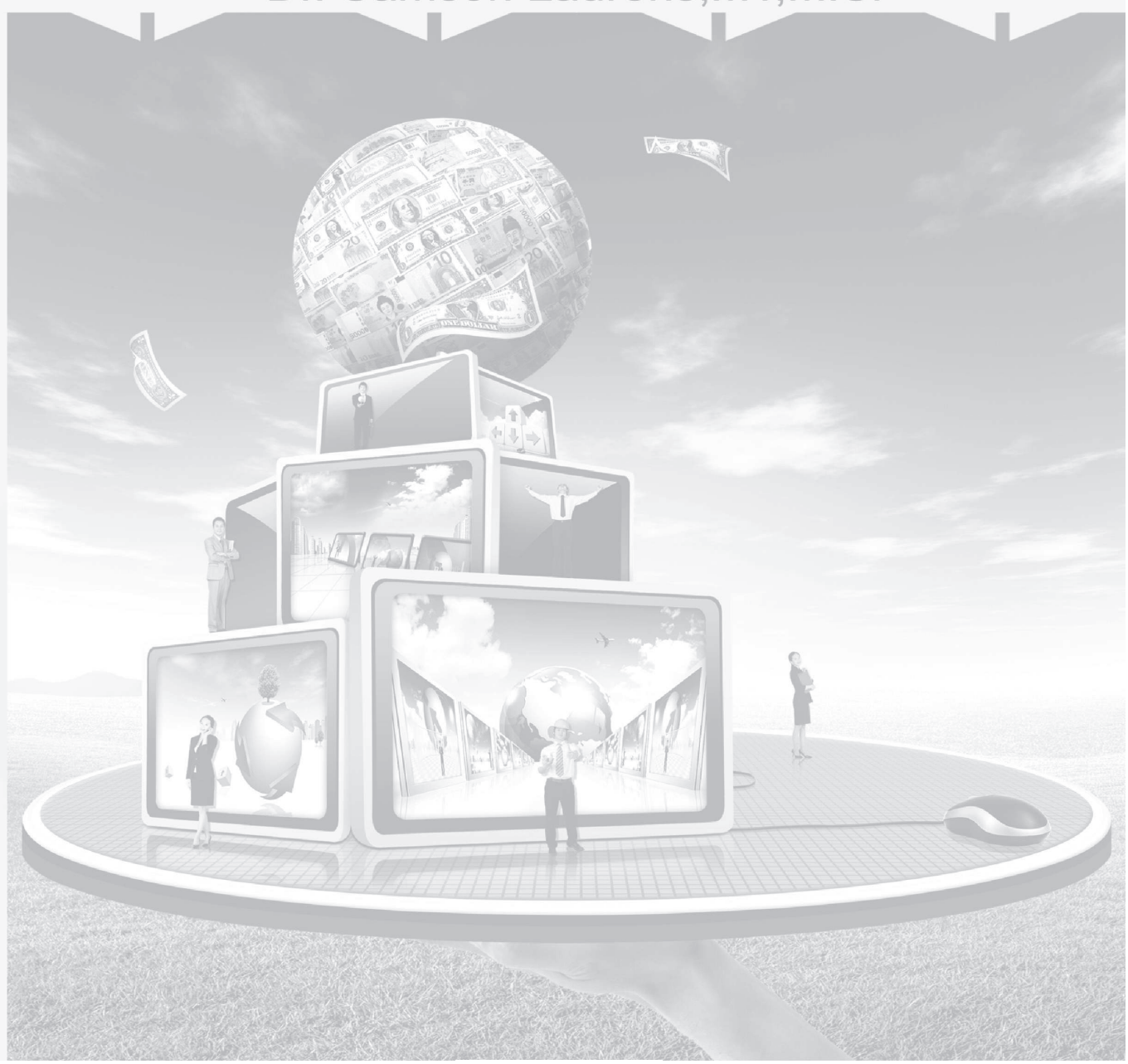




\title{
PELAYANAN PENGADAAN BARANG DAN JASA PUBLIK BERDIMENSI BIAYA TRANSAKSI
}

\author{
Copyright (C) Dr. Samson Laurent, MT, M.Si
}

Diterbitkan pertama kali oleh

Penerbit Pensil Komunika

Kavling Rewulu Wetan RT 4 RW 21 No.08-A

Sidokarto, Godean, Yogyakarta 55564

Isi dan Desain Cover bukan tanggungjawab penerbit

Penulis: $\quad$ Dr. Samson Laurent, MT, M.Si

Editor : $\quad$ Dr. Arifin Tapi Oyihoe, M.Si.

Desain Sampul : Memry Leonardo Tehubijuluw, SS.

Perpustakaan Nasional: Katalog Dalam Terbitan (KDT)

i + vi; 1 - 140, hlm.: $17.3 \times 23.5 \mathrm{~cm}$

ISBN : 978-602-71915-9-4

Undang-undang Republik Indonesia Nomor 19 Tahun 2012 tentang Hak Cipta

Lingkup Hak Cipta

Pasal 2 :

1. Hak Cipta merupakan hak eksklusif bagi pencipta atau pemegang Hak Cipta untuk mengumumkan atau memperbanyak ciptaannya, yang timbul secara otomatis setelah suatu ciptaan dilahirkan tanpa mengurangi pembatasan menurut peraturan perundang-undangan yang berlaku.

Ketentuan Pidana

Pasal 72:

1. Barang siapa dengan sengaja atau tanpa hak melakukan perubahan sebagaimana dimaksud dalam pasal 2 ayat (1) atau pasal 49 ayat (1) dan ayat (2) dipidana dengan penjara masing-masing paling singkat 1 (satu) bulan dan/atau denda paling sedikit Rp. 1.000.000,00 (satu juta rupiah), atau pidana penjara paling lama 7 (tujuh) tahun dan/atau denda paling banyak Rp. 5.000.000.000,00 (lima milyar rupiah).

2. Barang siapa dengan segaja menyiarkan, memamerkan, mengedarkan, atau menjual kepada umum suatu Ciptaan atau barang hasil pelanggaran Hak Cipta atau Hak Terkait sebagaimana dimaksud pada ayat (1) dipidana dengan penjara paling lama 5 tahun dan/atau denda paling banyak Rp. 500.000.000,00 (lima ratus juta rupiah). 


\section{KATA PENGANTAR}

Keterbatasan literatur tentang biaya transaksi (transaction cost) khususnya pada organisasi pelayanan publik menjadi hal penting yang melatarbelakangi penyusunan buku ini. Teori biaya transaksi memberikan kerangka acuan sebagai penjelasan umum terhadap titik pijak/organisasi sebagai mekanisme guna mendukung keputusan pada kondisi ketidakpastian dan mencegah sifat opportunistis terhadap pertukaran. Dalam perspektif organisasi pemerintah, maka biaya transaksi pada umumnya selalu diperhadapkan pada adanya permasalahan yang berkaitan dengan biaya pemerintah yang dikeluarkan dan biaya pasar yang harus disesuaikan dengan kebutuhan pelayanan. Biaya transaksi dipengaruhi oleh besarnya biaya pemerintah dan penetapan penyesuaian biaya pasar.

Buku ini membahas tentang biaya transaksi pada organisasi pelayanan publik, dengan studi kasus pada Biro Keuangan dan Kekayaan Sekretariat Daerah Provinsi Maluku. Buku ini terbagi ke dalam 8 bagian, yang diawali dengan penjelasan konsepkonsep yang berkaitan dengan biaya transaksi dan dilanjutkan dengan bagian yang menjelaskan contoh kasus perhitungan biaya transaksi pengadaan barang dan jasa pada Biro Keuangan dan Kekayaan Sekretariat Daerah Provinsi Maluku. Buku ini memberikan perpektif yang menyeluruh mengenai biaya transaksi pada organisasi pelayanan publik.

Terima kasih penulis sampaikan kepada semua pihak yang telah memberikan bantuan, baik secara moril maupun materil sehingga penulisan buku ini dapat terselesaikan.

Ambon, Januari 2015

Penulis 
iv $=$ 


\section{DAFTAR ISI}

Kata Pengantar.................................................................................. ii

Daftar Isi .....................................................................................

BAGIAN I PENDAHULUAN ................................................... 1

BAGIAN II RUANG LINGKUP KAJIAN BIAYA TRANSAKSI DALAM ADMINISTRASI PUBLIK .............................................. 7

A. Konsep Administrasi Publik ....................................... 7

B. Konsep Pemerintah .............................................. 12

C. Pelayanan Publik dan Transaction cost ...................... 16

BAGIAN III VARIAN KONSEP BIAYA TRANSAKSI _.............................. 19

A. Konsep Biaya Pemerintah........................................ 19

B. Konsep Biaya Pasar ................................................ 23

C. Biaya Transaksi .................................................... 29

D. Biaya Transaksi Pemerintah .................................... 33

BAGIAN IV KONTEKS PENGADAAN BARANG DAN JASA PEMERINTAH 39

A. Anggaran Pengadaan ATK dan Pemeliharaan Kendaraan Dinas ...................................................... 39

BAGIAN V ANALISIS PROSES PENGADAAN ALAT TULIS KANTOR (ATK) 63

BAGIAN VI PERSPEKTIF PROSES PENGADAAN BARANG DAN JASA...... 83

BAGIAN VII PERSPEKTIF BIAYA TRANSAKSI PADA BASIS

PELAYANAN PUBLIK................................................... 97

A. Konsep Pelayanan Publik ....................................... 97

B. Kesesuaian pelayanan ........................................... 97

BAB VIII PENUTUP ............................................................ 129

DAFTAR PUSTAKA 
vi 


\section{BAGIAN I}

\section{PENDAHULUAN}

Tulisan para pakar yang membicarakan perspektif transaction cost, yang selanjutnya disebut sebagai biaya transaksi khususnya dalam proses pelayanan publik saat ini masih sangat minim. Hal ini disebabkan belum adanya kajian mendalam terkait dengan permasalahan spesifik pelayanan dikaitkan dengan perspektif biaya transaksi. Lebih daripada itu kajian dan analisis terhadap biaya transaksi dari sudut pandang pemerintah masih belum optimal.

Padahal dalam kerangka untuk mewujudkan pemerintahan yang baik dibutuhkan kepastian hukum dan kemauan yang baik (goodwill) dari pemerintah untuk melakukan tata kelola administrasi dan keuangan yang sesuai dengan kesesuaian pelayanan dalam melakukan biaya transaksi (transaction cost) atas biaya pemerintah (government cost) dan biaya pasar (market cost). Pemerintah sebagai lembaga yang berorientasi publik (public oriented) harusnya mengutamakan pelayanan yang baik kepada masyarakat, namun berdasarkan hasil wawancara penulis terhadap beberapa masyarakat yang dilayani merasa pelayanannya tidak sesuai dengan harapan bahkan jika masyarakat tidak memberikan bayaran biasanya dipersulit. Pemerintah dalam memberikan pelayanan terkadang tergantung dari besarnya uang yang dibayarkan oleh masyarakat.

Salah seorang pakar dalam kaitannya dengan pelayanan berbasis biaya transaksi adalah bahwa Pesch, James (2005: 177) telah menetapkan biaya transaksi selalu mempertimbangkan biaya pemerintah dan biaya pasar dalam menentukan kesesuaian layanan yang diberikan. Teulings, Marshall (2003: 67) menyatakan penetapan biaya transaksi tidak terlepas dari adanya kepentingan pemerintah untuk mengelola biaya yang efektif dalam mengambil sebuah keputusan mengenai kegiatan layanan yang diterapkan.

Dengan demikian bahwa biaya transaksi pada umumnya selalu diperhadapkan pada adanya permasalahan yang berkaitan dengan biaya pemerintah yang dikeluarkan dan biaya pasar yang harus disesuaikan dengan kebutuhan pelayanan. Waarden, Van Burd (2006: 120) menyatakan biaya transaksi dipengaruhi oleh besarnya biaya pemerintah dan penetapan penyesuaian biaya pasar. Klein, Howard J. and Jay S. Kim, 2000 (2000: 90) menyatakan kinerja suatu organsisasi dalam memberikan pelayanan dilihat dari biaya transaksi yang dikenakan. Biaya transaksi yang berimbang adalah terpenuhinya kesesuaian antara biaya layanan dan manfaat kepentingan yang diperoleh. 
Secara empirik beberapa kasus menunjukkan bahwa dewasa ini pada kebanyakan organisasi pemerintah yang ada di Indonesia berbasis layanan, selalu menetapkan biaya transaksi yang tidak sesuai dengan biaya permintaan pemerintah dan tidak sesuai dengan biaya pasar, dalam mempengaruhi kesesuaian pelayanan. Ruiter, Milton (2008: 15) menyatakan biaya transaksi merupakan asumsi perilaku manusia dalam menetapkan suatu biaya yang rasional dan menguntungkan. Asumsi perilaku menetapkan berdasarkan asumsi keinginan antara layanan dan kepentingan. Williamson (1996: 165) menyatakan biaya transaksi merupakan perwujudan layanan dan kepentingan pencapaian tujuan organisasi.

Pada umumnya bahwa biaya transaksi yang dilakukan oleh pemerintah adalah dipengaruhi oleh besarnya biaya pengeluaran pemerintah dan penyesaian biaya pasar. Williamson (1996: 170) menyatakan biaya transaksi yang diterapkan mengacu pada pertimbangan biaya pemerintah berupa biaya rutin, biaya pembangunan, biaya kebutuhan SDM dan biaya untuk pengadaan sarana prasarana. Black (2007: 89) menyatakan biaya transaksi yang diterapkan selalu menyesuaikan biaya pasar sesuai dengan pembiayaan biaya negosiasi, biaya monitoring, biaya pertukaran dan biaya evaluasi. Antara biaya pemerintah dan biaya penyesuaian pasar sangat menentukan penetapan biaya transaksi yang dilakukan oleh pemerintah dalam mempengaruhi penyesuaian layanan yang diberikan. Fenomena ini terjadi pada Biro Keuangan dan Kekayaan Sekretariat Daerah Provinsi Maluku dalam menentukan biaya transaksi.

Pada prinsipnya Biro Keuangan dan Kekayaan Sekretariat Daerah Provinsi Maluku dalam menjalankan tugas pokok dan fungsinya mengacu kepada Peraturan Gubernur Maluku Nomor 56 Tahun 2009 tentang uraian tugas Sekretariat Daerah Provinsi Maluku. Hal yang berkaitan dengan biaya transaksi dalam pelaksanaan uraian kerja yaitu berkaitan dengan biaya transaksi aset, biaya program dan biaya kegiatan yang dilakukan dalam melayani unit kerja instansi pemerintah yang ada dalam naungan Sekretariat Daerah.

Permasalahan lain bahwa esensi dan wujud biaya pemerintah yang sering menimbulkan permasalahan berkaitan dengan biaya transaksi yaitu biaya rutin yang tidak sesuai dengan pengalokasiannya, biaya pembangunan yang tidak sesuai dengan peruntukan, biaya untuk kebutuhan SDM tidak sesuai dengan pemanfaatan dan biaya pengadaan sarana prasarana tidak sesuai dengan ketersediaan fasilitas kerja. Stephen (2005:90) menyatakan biaya pemerintah dialokasikan sesuai dengan usulan kebutuhan dan prioritas. 
Oleh karena itu bahwa salah satu hambatan dalam menentukan besarnya biaya pemerintah, tergantung dari kebutuhan alokasi biaya rutin, biaya pembangunan, biaya kebutuhan SDM dan biaya pengadaan sarana dan prasarana. Alokasi permintaan usulan anggaran dari masing-masing unit organisasi mempengaruhi biaya transaksi yang berkaitan dengan penyesuaian wujud layanan yang diterapkan. Ruiter, Milton (2008: 149) menyatakan biaya pemerintah mempengaruhi biaya transaksi tergantung pada besarnya alokasi anggaran yang diprioritaskan sesuai peruntukannya.

Besarnya biaya pemerintah yang diusulkan, mempengaruhi biaya transaksi dari setiap pos-pos pengalokasian pembiayaan berupa biaya transaksi informasi, administrasi, operasional dan teknologi. Penambahan biaya transaksi sering tidak bersesuaian antara wujud layanan yang diberikan dengan terpenuhinya kepentingan dari suatu proses pelayanan yang diharapkan. Ruiter, Milton (2008: 153) menyatakan biaya transaksi diperlukan untuk kelancaran layanan dan terpenuhinya kepentingan yang diharapkan dari sebuah proses layanan birokrasi.

Biro Keuangan dan Kekayaan Sekretariat Daerah Provinsi Maluku dalam melakukan penetapan biaya transaksi selalu mempertimbangkan kondisi biaya pasar. Biaya pasar merupakan sebuah penetapan biaya yang didasarkan pada mekanisme pasar dalam menentukan produk dan jasa yang menjadi obyek transaksi. Steenge, Jerry (2008: 171) menyatakan bahwa biaya pasar merupakan biaya bentukan dari mekanisme pasar yang mempengaruhi penetapan biaya transaksi produk dan jasa.

Aspek yang menentukan biaya pasar dalam mempengaruhi biaya transaksi ditentukan oleh aspek negosiasi, monitoring, pertukaran dan evaluasi, yang memiliki pos-pos biaya dalam proses penetapannya. Biaya negosiasi biasanya ditentukan oleh pelaksana yang berkepentingan dalam menetapkan biaya yang berlaku, biaya monitoring terjadi dari pelaporan yang ditemukan, biaya pertukaran dilakukan berdasarkan aspek perbaikan dan penggantian produk barang/jasa, serta biaya evaluasi dikeluarkan berdasarkan hasil penilaian dari program dan kegiatan yang dilakukan.

Fakta tersebut banyak ditemukan dalam penetapan biaya transaksi yang dilakukan pada Biro Keuangan dan Kekayaan Sekretariat Daerah Provinsi Maluku khususnya dalam penetapan biaya usulan suatu program atau kegiatan yang mengeluarkan biaya transaksi dalam mensosialisasikan anggaran yang dikeluarkan. Sosialisasi anggaran yang keluar selalu mempertimbangkan biaya pasar yang sesuai dengan mekanisme pasar dalam menetapkan biaya negosiasi, monitoring, pertukaran dan evaluasi. 
Terjadinya sebuah kesenjangan dalam mempertanyakan biaya transaksi yang ditetapkan, yang penetapannya tidak dilakukan secara profesional dalam mempertimbangkan besarnya biaya pemerintah dan biaya pasar dalam mempengaruhi suatu kegiatan birokrasi dan pelayanan. Besarnya biaya transaksi cenderung berdampak ketidaksesuaian pelayanan berdasarkan prinsip layanan, akuntabilitas layanan, kepemimpinan layanan, produktivitas dan kualitas pelayanan.

Peningkatan biaya transaksi ditentukan oleh besarnya biaya informasi, administrasi, operasional dan penggunaan teknologi dalam melakukan kegiatan pelayanan. Karenanya diperlukan adanya sebuah standar penetapan biaya yang disesuaikan dengan kegiatan layanan yang efisien dan efektif. Kenyataan lapangan sesuai dengan cermatan empirik pada Biro Keuangan dan Kekayaan Sekretariat Daerah Provinsi Maluku dalam mengelola biaya informasi, administrasi, operasional dan teknologi cenderung tidak dibarengi dengan kesesuaian layanan.

Kesesuaian pelayanan akan terwujud jika biaya transaksi dilakukan secara proporsional berdasarkan layanan dan kepentingan pemerintah dalam mendorong terwujudnya prinsip pelayanan yang tepat, akuntabilitas layanan yang dapat dipercaya, kepemimpinan layanan yang berorientasi tujuan, produktivitas berorientasi hasil dan kualitas layanan yang memuaskan.

Beberapa informasi di atas menunjukkan bahwa biaya transaksi dipengaruhi oleh biaya yang dibutuhkan pemerintah untuk melaksanakan tugas pokok dan fungsi, dan dipengaruhi biaya pasar dalam menetapkan besarnya keperluan penetapan barang/jasa. Melalui biaya transaksi yang tepat akan berpengaruh terhadap terwujudnya kesesuaian pelayanan organisasi.

Pada kasus biaya transaksi yang dikeluarkan oleh pihak Pemerintah Provinsi Maluku tentu menjadi tanda tanya penggunaannya, efisiensi dan efektivitasnya. Kita selalu berharap agar penggunaan anggaran efisien dan tepat sasaran. Tulisan ini lebih diangkat berdasarkan perspektif temuan penelitian yang difokuskan pada proses pengadaan barang/jasa pada Biro Keuangan dan Kekayaan Sekretariat Daerah Provinsi Maluku. Biaya transaksi pengadaan barang/jasa ada setiap tahun dan sistemnya pada dasarnya sama setiap tahun. Untuk itu, peneliti cukup mengambil 1 tahun saja yakni tahun terakhir pada saat dilakukan penelitian yaitu data tahun terakhir pada saat penelitian yaitu data tahun 2011. Pada Biro Keuangan dan Kekayaan Sekretariat Daerah Provinsi Maluku pada tahun 2011 diperoleh data 8 prgram yang meliputi 34 kegiatan yang dalam implementasinya menggunakan biaya transaksi. Hal ini tentu sangat luas sehingga perlu dibatasi. Sehubungan dengan itu, penulis cukup memilih 1 sampel 
pengadaan barang dan 1 sampel pengadaan jasa. Untuk pengadaan barang penulis memilih pengadaan ATK dan untuk pengadaan jasa penulis memilih pemeliharaan kendaraan dinas.

Upaya untuk menganalisis biaya transaksi pengadaan barang/jasa, salah satu acuan adalah pendekatan teori yaitu teori informasi asimetri (asymmetric information), teori perilaku peluang (opportunity behavior) dan teori nilai ekonomis efisiensi (efficiency economic value). Semakin banyak manfaat dari transaksi yang diterapkan, semakin besar nilai ekonomis dilakukan oleh organisasi (Wittman, DA. 2004: 246).

Berdasarkan analisis tersebut, maka proses pengadaan barang/jasa perlu dianalisis dengan menggunakan pendekatan teori asymmetric information, opportunity behavior dan efficiency economic value dan analisis efisiensi dan efektivitas biaya transaksi. Diasumsikan bahwa proses pengadaan barang ATK yang melalui penunjukan langsung kurang efisien dan kurang efektif, demikian halnya proses pengadaan jasa pemeliharaan kendaraan dinas melalui pelelangan umum kurang efisien dan kurang efektif sehingga perlu dianalisis dalam pendekatan transaction cost. 


\section{BAGIAN II}

\section{RUANG LINGKUP KAJIAN BIAYA TRANSAKSI DALAM ADMINISTRASI PUBLIK}

\section{A. Konsep Administrasi Publik}

Pada prinsipnya ilmu administrasi publik merupakan sebuah disiplin ilmu dan seni yang mempelajari hal-hal yang berkaitan dengan berbagai pertimbangan untuk melihat hubungan pemerintah dengan publik sesuai dengan makna administrasi publik, yang secara etimologi administrasi, kata administrasi berasal dari bahasa Latin Yunani terdiri atas dua kata, "ad" dan "ministrate" yang berarti "to serve" yang dalam Bahasa Indonesia berarti melayani dan atau memenuhi (Rondinelli, Dennis A, 1981: 15). Dipahami bahwa administrasi adalah suatu prose pelayanan atau pengaturan.

Permasalahan pokoknya adalah "siapa" yang harus "melayani" dan "dilayani". Jawaban yang pasti, tidak lain dan tidak bukan adalah manusia itu sendiri. Manusia yang harus menjaga keteraturan kehidupan sosialnya dan manusia itu sendiri yang harus menjaga keteraturan kehidupan sosialnya dan manusia itu sendiri yang harus memecahkan seluruh permasalahan kehidupan sosialnya. Jelasnya adalah manusia berperilaku melayani dan mengatur dirinya sendiri untuk eksistensi dan tujuan hidupnya mulai tingkat individu sampai pada tingkat sosial umumnya.

Jadi administrasi merupakan suatu fenomena sosial dan hidup dalam kehidupan sosial publik. Di dalam tingkat kehidupan demikian individu mempunyai peranan penting karena sebenarnya publik ialah bentuk kehidupan antar individu dalam suatu sistem, untuk mencapai tujuan. Oleh karena itu, setiap individu berfungsi sebagai sumber daya publik, sekaligus sumber daya administrasi.

Simon, S. (1999: 3) mendefinisikan administrasi sebagai kegiatan kelompok kerjasama untuk mencapai tujuan bersama. Syafiie dkk (1999) mendefinisikan administrasi adalah suatu proses yang umum ada pada usaha kelompok, baik pemerintah maupun swasta.

Pasolong, H. (2007: 3) administrasi sebagai keseluruhan proses kerjasama antara dua orang manusia atau lebih yang didasarkan atas rasionalitas tertentu mencapai tujuan yang telah ditentukan sebelumnya. Administrasi menjadi rangkaian kegiatan terhadap pekerjaan yang dilakukan oleh sekelompok orang di dalam kerjasama mencapai tujuan tertentu. Administrasi merupakan pekerjaan terencana yang dilakukan 
oleh sekelompok orang dalam bekerjasama untuk mencapai tujuan atau dasar efektif, efisien dan rasional.

Berdasarkan pengertian administrasi tersebut di atas, dikaitkan dengan biaya transaksi dari suatu pelayanan publik, Gibson (1997: 38) mengatakan bahwa biaya transaksi pelayanan diterapkan dalam mempermudah pembiayaan kegiatan pelayanan untuk pencapaian sasaran dari upaya bersama. Derajat pencapaian sasaran menunjukkan derajat pentingnya biaya transaksi pelayanan yang diperlukan dalam melakukan kegiatan pelayanan publik.

Dalam aplikasi administrasi, biaya transaksi diperlukan dalam pelaksanaan suatu kegiatan pelayanan. Tjokroamidjojo (2004: 3) mengatakan administrasi adalah pencapaian hasil seperti yang direncanakan, dilaksanakan dan diberdayakan sesuai dengan tujuan, namun keberhasilan dari tujuan tersebut membutuhkan adanya pembiayaan. Keban (2004: 140) menyatakan suatu organisasi menerapkan biaya transaksi pelayanan untuk mempermudah implementasi kebutuhan pelayanan.

Tujuan yang ingin dicapai melalui kegiatan administrasi adalah menerapkan kemampuan dan keterampilan kerja, sehingga tercapai tujuan secara efektif yang didukung oleh ketersediaan biaya dalam menjalankan aktivitas dinamika organisasi sesuai dengan besarnya biaya transaksi yang diterapkan.

Suatu kegiatan pelayanan mengandung keterkaitan dengan publik. istilah publik yang berarti umum, rakyat umum, orang banyak dan publik. Nampaknya keberadaan administrasi sering digandengkan dengan perkataan publik yang disebut administrasi publik. Administrasi publik adalah suatu kegiatan pelayanan terhadap sejumlah orang atau publik yang membutuhkan pelayanan. Sebaliknya suatu pelayanan akan terselenggara apabila didukung oleh adanya pembiayaan, berarti biaya transaksi dari suatu kegiatan berperan penting dalam memperlancar kegiatan pelayanan.

Pengertian publik menurut Syafiie (1999: 15) bahwa publik adalah sejumlah pelayanan yang dibutuhkan oleh publik berdasarkan adanya persamaan berpikir, perasaan, harapan, sikap dan tindakan yang benar-benar diperuntukkan untuk melayani. Pada prinsipnya hal yang menjadi persamaan persepsi dalam memperlancar suatu pelayanan adalah pemikiran tentang biaya transaksi pelayanan yang dibutuhkan.

Sementara menurut Frederickson (1997: 46) bahwa konsep publik merujuk pada beberapa dimensi sebagai berikut: 1) publik sebagai kelompok kepentingan dilihat dari manifestasi interaksi kelompok yang melahirkan kepentingan publik sesuai kebutuhan biaya; 2) publik sebagai pilihan yang rasional dalam memenuhi kepentingan orang lain 
yang mengeluarkan biaya; 3) publik sebagai wujud kepentingan publik sebagai suara pelayanan yang mengerti tentang biaya transaksi pelayanan; 4) publik sebagai pelayanan yang harus dipenuhi sesuai dengan nilai biaya pelayanan yang diberikan; dan 5) publik sebagai warga negara yang harus berpartisipasi dalam menyelenggarakan pemerintahan dalam membantu pembiayaan pelayanan.

Konsep publik ini mempunyai keterkaitan dengan administrasi. Konsep administrasi publik di Indonesia pada dasarnya diartikan sebagai bentuk kegiatan proses di dalam memberikan penjelasan-penjelasan tentang seni dan ilmu yang mengurusi urusan publik. Atas dasar tersebut, Rakhmat (2009: 2) apa yang disebut dengan teori dan paradigma administrasi. Teori adalah seperangkat konstruk yang saling berhubungan melalui definisi dan proposisi yang menyajikan suatu pandangan sistematik tentang fenomena melalui penetapan hubungan diantara berbagai variabel dengan maksud menjelaskan dan meramalkan fenomena.

Silalahi, Ulbert (1999: 5) menjelaskan bahwa dalam kajian ilmu administrasi publik diperlukan adanya seperangkat proposisi yang berhubungan secara logis dan nyata, secara sistematis menjelaskan seperangkat gejala-gejala empiris. Seperti proposisi setiap kegiatan pelayanan membutuhkan pengorbanan. Salah satu bentuk pengorbanan adalah pengorbanan biaya untuk mendapatkan pelayanan yang terbaik.

Shah, Haryono (1987) minimal ada tiga hal yang terkait dengan sebuah teori administrasi yang terkait dengan penjelasan aplikasinya seperti aplikasi penerapan pelayanan publik dalam suatu birokrasi pemerintah yaitu: 1) teori sebagai perangkat proposisi; 2) teori sebagai penjelasan hubungan antara variabel yang dapat diterangkan dan dijelaskan dan 3) teori sebagai fenomena dalam menjelaskan hubungan variabel yang spesifik. Contohnya bagaimana membangun sebuah teori biaya transaksi yang menyatakan bahwa tujuan organisasi adalah meminimalkan biaya dari pertukaran sumber daya dalam lingkungan kerja dan biaya pengelolaan pertukaran dalam sisi organisasi.

Dari dasar teori ini kemudian dapat berbentuk definisi, tesis, deskripsi, eksplorasi, normasi dan prinsip yang melahirkan adanya suatu paradigma yang menjadi konsep. Rakhmat (2009: 4) menyatakan paradigma adalah revolusi sains yang diperuntukkan untuk memecahkan berbagai permasalahan dalam menjelaskan hal yang penting dari suatu ilmu termasuk dalam hal ini paradigma administrasi publik. Contoh, seperti paradigma bahwa setiap kegiatan pelayanan membutuhkan biaya.

Paradigma administrasi publik menurut Waldo, Widodo (1991: 17) menyatakan administrasi publik adalah terjadinya suatu kegiatan pelayanan secara efisien, efektif 
dan rasionalitas sesuai dengan kewenangan yang tersusun secara hirarki, termasuk dalam hal ini bagaimana melihat hubungan administrasi publik dengan biaya transaksi pelayanan sebagai bentuk dari proses kegiatan yang harus dijalankan secara efisien menurut penggunaan waktu dalam penetapan biaya sesuai dengan kegunaan pembiayaan dilakukan secara rasionalitas.

Dari paradigma ini lahirlah sebuah teori yang disebut teori struktural fungsional yang diperankan oleh Max Weber. Tjokroamidjojo (2004: 51) menyatakan bahwa administrasi adalah pelaksanaan dari suatu kegiatan yang dijalankan oleh pihak pemerintah berdasarkan hirarki struktur sesuai fungsinya. Contoh, bagaimana secara struktural suatu kegiatan pelayanan membutuhkan adanya pembiayaan dalam rangka memperlancar suatu pencapaian tujuan. Ini berarti biaya transaksi secara struktural mempunyai peranan untuk memperlancar aktivitas pelayanan dan secara fungsional biaya menjadi unsur yang menentukan suatu kegiatan pelayanan.

Secara konkrit bentuk kegiatan administrasi publik dalam bentuk pelayanan dapat digunakan adanya teori mekanis yang dikemukakan Rakhmat (2009: 7) memandang administrasi dalam pelayanan publik berfokus kepada mekanisme dan sistem kerja, untuk menghasilkan hasil kerja yang berefek pada kepuasan publik dan pengakuan pemerintah. Termasuk dalam hal ini setiap kegiatan dari mekanisme, sistem kerja dan hasil kerja yang dicapai tidak terlepas dari peranan biaya transaksi pelayanan.

Mengkaji teori administrasi publik, melibatkan adanya teori birokrasi. Rakhmat (2009: 9) birokrasi merupakan ciri dari pola organisasi yang struktural yang memanfaatkan sumber daya manusia untuk memberikan pelayanan yang terbaik sesuai dengan kemampuan pembiayaan.

Teori birokrasi ini akhirnya melahirkan adanya suatu ilmu administrasi mengenai sistem administrasi yang berjalan berdasarkan prinsip administrasi sebagai instrumen yang penting untuk pencapaian tujuan publik. Dasar pengembangan tujuan birokrasi sangat berkaitan dengan adanya reformasi administrasi. Zauhar, Mansyur (1999: 34) menyatakan reformasi administrasi adalah penyempurnaan tatanan, metode dan kinerja untuk memberikan pelayanan yang terbaik kepada publik. Ini berarti eksistensi dari suatu reformasi memerlukan adanya biaya transaksi dalam menjalankan penyempurnaan dalam suatu tatanan, metode dan kinerja.

Pandangan-pandangan tersebut menjadi dasar bagi peneliti untuk melihat bagaimana prospektif sudut pandang ilmu administrasi publik tentang biaya transaksi pelayanan. Pelayanan dalam ilmu administrasi publik merupakan sesuatu yang sangat 
diperlukan. Pentingnya pelayanan dalam aplikasi publik terkait dengan konsep layanan publik sesuai tingkat biaya transaksi yang diterapkan.

Dalam definisi administrasi publik, pelayanan diartikan sebagai aktivitas seseorang, kelompok dan organisasi untuk memenuhi kebutuhan publik. Moenir (2003: 49) menyatakan pelayanan dalam tinjauan administrasi publik merupakan proses pemenuhan kebutuhan melalui aktivitas yang melibatkan adanya pihak yang memberi dan menerima pelayanan untuk memenuhi kebutuhan publik. Ini berarti suatu kegiatan pelayanan akan melahirkan sebuah transaksi pelayanan. Dan transaksi pelayanan cenderung diidentikkan dengan adanya penggunaan biaya pelayanan.

Dalam pengembangan ilmu administrasi pelayanan publik, Sinambela (2005: 5) pelayanan adalah kegiatan yang dilakukan oleh pemerintah yang menguntungkan publik dengan menawarkan kepuasan atas berbagai kegiatan layanan, tanpa mengabaikan pentingnya biaya transaksi pelayanan.

Keberadaan pelayanan publik dalam era pemerintahan yang melaksanakan otonomi daerah, secara administratif pelayanan publik diartikan sebagai kemampuan dan kesiapan aparat pemerintah dalam memberikan pelayanan kepada publik yang mempunyai kepentingan terhadap kegiatan untuk memenuhi kesejahteraan pelayanan publik. Inti dari keterkaitan dalam kepentingan ini yaitu terjalinnya biaya transaksi pelayanan.

Pemahaman tentang pelayanan publik dalam tinjauan administrasi mempunyai keterkaitan dengan adanya perubahan dalam suatu organisasi dalam menetapkan biaya transaksi. Teori perubahan dalam sebuah model sistem organisasi, melibatkan adanya eksistensi manusia dalam menjalankan tugas sesuai dengan desain, strategi yang didasari oleh kultur untuk mengembangkan teknologi. Model sistem ini dikenal dengan model sistem perubahan (Hellriegel, 1998: 581).

Dalam model sistem perubahan, manusia sangat elastisitas melakukan perubahan yang terkait dengan tugasnya, caranya dalam mendesain, dipengaruhi oleh biaya transaksi di dalam mengembangkan strategi dengan menggunakan teknologi untuk memberikan pelayanan terbaik (Winardi, 2004: 76).

Uraian tersebut merupakan pengantar untuk memahami bagaimana penerapan biaya transaksi pelayanan berdasarkan landasan teori, konsep dan definisi administratif yang memberikan eksistensi bahwa pelayanan sangat diperlukan di dalam suatu pemerintahan yang menerapkan prinsip-prinsip administrasi publik, tanpa mengabaikan pentingnya biaya transaksi. 


\section{B. Konsep Pemerintah}

Birokrasi pemerintahan merupakan istilah yang mempunyai pertalian dengan berbagai penerapan administrasi publik. Istilah birokrasi berasal dari kata Yunani yaitu bureau yang artinya meja tulis yaitu tempat para pejabat bekerja atau dapat diartikan sebagai arti lain yaitu aturan. Albrow (1989: 3) menyatakan birokrasi identik dengan kata bureau yang artinya kekuasaan pejabat dalam pemerintahan.

Weber dalam H.G. Surie (1987: 99) definisi birokrasi pemerintahan adalah suatu daftar tentang ciri dan sifat yang mempunyai hubungan tentang suatu pelaksanaan jabatan yang diemban oleh aparat pemerintah untuk diterapkan dengan baik. Contoh, termasuk dalam hal ini penetapan biaya transaksi pelayanan.

Kristiadi (1994: 93) pemerintah adalah struktur organisasi pemerintahan yang bertugas untuk mengembangkan penyelenggaraan pelayanan umum dan pembangunan. Kegiatan birokrasi adalah menjalankan tugas pelayanan sebagai pengembangan unit organisasi pemerintahan. Santosa (2008: 29) mendefinisikan birokrasi adalah keseluruhan tugas organisasi pemerintahan untuk menjalankan segala bentuk kegiatan pelayanan untuk mensejahterakan publik.

Kajian tentang birokrasi pemerintahan pada prinsipnya adalah menempatkan suatu jabatan tentang penyelenggara pemerintahan untuk bekerja secara efisien dan efektif. Keterkaitannya dengan konsep birokrasi pemerintahan yang diterapkan di Indonesia, pengertian birokrasi pemerintahan disepadankan dengan arti birokrasi administrasi publik, atau pelaksana pelayanan publik. Robert H (2000: 40) menyatakan birokrasi pemerintahan adalah pelaksana pelayanan kepada publik yang dilakukan oleh pejabat pemerintah sesuai dengan pembagian tugas yang diemban.

Hal ini disesuaikan dengan pendekatan birokrasi yang menggunakan teori Max Weber dalam Pasolong, H. (2007: 70) yang menyatakan bahwa pelaksanaan birokrasi pemerintahan dijalankan oleh struktur pelaksana pemerintah secara rasional, efisien dan sesuai dengan tuntutan pemenuhan publik. Kast \& Rozenweig (1982: 78) menyatakan birokrasi pemerintahan adalah kemampuan pelaksana pemerintah dalam mengkoordinasikan semua aktivitas organisasi dalam melayani kebutuhan publik.

Proposisi birokrasi pemerintahan berdasarkan Weber dalam Pasolong, H. (2007: 71) terdapat delapan proposisi yang menyusun sistem otoritas legal suatu tindakan pelayanan birokrasi yaitu: 1) tugas yang terorganisir, 2) bidang kerja yang sesuai fungsi kerja, 3) jabatan yang tersusun secara terorganisir, 4) aturan yang sesuai dengan tuntutan pelayanan, 5) sumber daya pengembang pelayanan, 6) jabatan bidang 
pelayanan, 7) aksessibilitas pelayanan administratif, dan 8) sistem otoritas pelayanan birokrasi. Kedelapan tindakan pelayanan birokrasi berjalan dengan lancar apabila ditunjang oleh adanya biaya transaksi pelayanan yang diterapkan untuk memenuhi tuntutan pelayanan publik.

Mengembangkan teori birokrasi pemerintah dalam memberikan pelayanan publik, Setiyono (2005: 16-20) mengklasifikasikan lima teori birokrasi yang berkaitan dengan kegiatan pelayanan pemerintah yaitu:

a. Teori rasional model administrasi yang diperkenalkan oleh Max Weber yang menyatakan bahwa birokrasi yang ideal adalah birokrasi yang berdasarkan pada sistem peraturan yang rasional dalam pelayanan.

b. Teori model power block yaitu teori berdasarkan pemikiran birokrasi yang merupakan alat penghalang (blok) bagi publik untuk melaksanakan kekuasaannya. Birokrasi dipandang sebagai pembendung kekuasaan rakyat, karenanya diperlukan adanya kekuatan untuk mendorong pemerintah memberikan pelayanan terbaik kepada publik.

c. Teori model birokrasi over suplay yaitu teori yang menempatkan pelayanan birokrasi harus dikurangi mengingat perannya tidak mensejahterakan publik.

d. Teori pelayanan publik baru yaitu anti-tesis (penentangan) tentang pemikiran birokrasi yang tidak memberikan pelayanan terbaik kepada publik.

e. Teori biaya transaksi yaitu suatu kegiatan pelayanan akan mudah mencapai tujuan jika dalam pelaksanaannya ditunjang oleh pembiayaan yang kuat.

Selain itu, dalam penerapan birokrasi pemerintahan dikenal adanya teori birokrasi Osborne. Teori ini berkaitan dengan reinventing government yang telah diperkenalkan oleh Osborne, David dan Gaebler, Ted. (2000: 152) menyatakan paradigma baru administrasi publik yang terkait dengan birokrasi pemerintahan yaitu keberhasilan suatu pelayanan akan terwujud bila biaya transaksi pelayanan ditetapkan dalam mendukung 10 prinsip bentuk pelayanan yaitu:

a. Steering rather than rowing. Pemerintah berperan sebagai katalisator yang tidak melaksanakan sendiri pembangunan tapi cukup mengendalikan sumber yang ada di publik. Dengan demikian pemerintah mengoptimalkan penggunaan dana dan daya sesuai dengan kepentingan pelayanan publik. 
b. Empower communities to solve their own problems, rather then merely deliver services. Pemerintah harus memberdayakan publik dalam pemberian pelayanannya.

c. Promote and encourage competition, rather than monopolies. Pemerintah harus menciptakan persaingan dalam setiap pelayanan publik.

d. Be driven by mission rather than rules. Pemerintah harus melakukan aktivitas yang menekankan pada pencapaian apa yang merupakan misi pelayanan publik.

e. Result oriented by funding outcomes rather than outputs. Pemerintah hendaknya berorientasi kepada kinerja pelayanan publik.

f. Meet the needs of the customer rather those of the bureaucracy. Pemerintah harus mengutamakan pemenuhan kebutuhan publik bukan kebutuhan birokrat.

g. Concentrate on earning money rather than just spending it. Pemerintah memiliki aparat yang tepat dalam memberikan layanan publik.

h. Invest in preventing problems rather than curing crises. Pemerintah yang antisipatif dalam setiap pelayanan publik.

i. Decentralize authority rather than build hierarchy sebagai partisipatif dalam pengembangan pelayanan publik oleh pemerintah.

j. Solve problem by influencing market forces rather than by treating public programs. Pemerintah memperhatikan kebutuhan publik akan pelayanan yang berkualitas.

Kesepuluh bentuk pelayanan ini akan terealisasi dengan baik bila ditunjang oleh adanya biaya transaksi pelayanan sebagai perekat dari masing-masing item dalam pengimplementasiannya. Warben (2004) dalam Genugten, Maria Lambetta Van. (2008: 7) menyatakan ekonomi biaya transaksi memperkuat organisasi atau institusi dalam menjalankan aktivitas pemerintahan dalam mencapai tujuan bersama pemerintah dan publik.

Selanjutnya birokrasi pemerintahan diperlukan dalam memberikan pelayanan kepada publik melalui penerapan banishing bureaucracy atau yang disebut dengan pembaruan birokrasi. Osborne, David Plastrik and Peter (1997: 78) memperkenalkan lima strategi pembaruan birokrasi pemerintah berkaitan dengan kemampuan pemerintah melaksanakan pelayanan kepada publik yaitu: 
a. Strategi inti (centre strategy) yaitu menata kembali secara jelas mengenai tujuan, peran, dan arah organisasi.

b. Strategi konsekuensi (consequence strategy) yakni strategi yang mendorong persaingan sehat guna meningkatkan motivasi dan kinerja pegawai melalui penerapan "reward and punishment" dengan memperhitungkan resiko ekonomi dan pemberian penghargaan.

c. Strategi publik (customer strategy) yaitu memusatkan perhatian untuk bertanggungjawab terhadap publik. Organisasi harus menang dalam persaingan dan memberikan kepastian mutu bagi publik.

d. Strategi kendali (control strategy) yaitu merubah lokasi dan bentuk kendali di dalam organisasi. Kendali organisasi dibentuk berdasarkan visi dan misi yang telah ditentukan. Dengan demikian terjadi proses pemberdayaan organisasi, pegawai dan publik.

e. Strategi budaya (cultural strategy) yakni merubah budaya kerja organisasi yang terdiri dari unsur kebiasaan, emosi dan psikologi, sehingga pandangan publik terhadap organisasi publik berubah.

Kembali ditegaskan bahwa kelima strategi dari pelayanan ini akan mudah diterapkan bila ditunjang oleh aspek biaya transaksi pelayanan. Adanya biaya transaksi pelayanan akan memberikan dampak besar dalam menetapkan suatu strategi untuk mencapai sasaran atau tujuannya.

Bentuk pelaksanaan birokrasi pemerintahan dalam aplikasi publik yang berkaitan dengan pelayanan berfokus kepada struktur birokrasi yang merupakan visualisasi tugas, fungsi, garis wewenang dan tanggungjawab, jabatan dan penilaian jabatan berdasarkan batasan birokrasi pemerintah dalam pelayanan. Bentuk pelaksanaan ini membutuhkan adanya biaya transaksi pelayanan (Genugten, Maria Lambetta Van. 2008: 7).

Gibson (1997: 9) mengatakan bahwa biaya transaksi pelayanan akan memperkuat struktur organisasi dalam mendukung pola formal mengelompokkan orang dan pekerjaan. Biaya transaksi pelayanan selalu melibatkan struktur organisasi yang berpengaruh terhadap perilaku individu dan kelompok dalam pencapaian suatu tujuan organisasi. 


\section{Pelayanan Publik dan Transaction cost}

Biaya transaksi dalam organisasi birokrasi mempengaruhi proses pelayanan publik. Organisasi birokrasi merupakan kesepakatan bersama tentang nilai bersama dalam kehidupan organisasi dan mengikat semua orang dalam organisasi yang bersangkutan (Siagian, P. Sondang, 1995: 62).

Organisasi birokrasi akan menentukan apa yang boleh dan tidak boleh dilakukan oleh para anggota organisasi; menentukan batas-batas normatif perilaku anggota organisasi; menentukan sifat dan bentuk-bentuk pengendalian dan pengawasan organisasi; menentukan gaya manajerial yang dapat diterima oleh para anggota organisasi; menentukan cara-cara kerja yang tepat, dan sebagainya. Secara spesifik peran penting yang dimainkan oleh organisasi birokrasi adalah membantu menciptakan rasa memiliki terhadap organisasi; menciptakan jati diri para anggota organisasi; menciptakan keterikatan emosional antara organisasi dan pekerja yang terlibat didalamnya; membantu menciptakan stabilitas organisasi sebagai sistem sosial; dan menemukan pola pedoman perilaku sebagai hasil dari norma-norma kebiasaan yang terbentuk dalam keseharian.

Begitu kuatnya pengaruh organisasi birokrasi terhadap perilaku para anggota organisasi, tidak terlepas dari andil biaya transaksi pelayanan. Organisasi birokrasi mampu menetapkan tapal batas untuk membedakan dengan organisasi birokrasi lain tergantung dari besarnya pembiayaan dalam menjalankan suatu transaksi pelayanan. Mampu membentuk identitas organisasi dan identitas kepribadian anggota organisasi; mampu mempermudah terciptanya komitmen organisasi daripada komitmen yang bersifat kepentingan individu; mampu meningkatkan kemantapan keterikatan sistem sosial; dan mampu berfungsi sebagai mekanisme pembuatan makna kendali perilaku para anggota organisasi.

Pelayanan publik sebagai suatu proses kinerja organisasi birokrasi, keterikatan dan pengaruh organisasi sangatlah kuat. Dengan kata lain, apapun kegiatan yang dilakukan oleh aparat pelayanan publik haruslah berpedoman pada rambu-rambu aturan normatif yang telah ditentukan oleh organisasi publik sesuai dengan besarnya biaya transaksi pelayanan.

Rondinelli, Dennis A. (1981: 58) pernah mengingatkan bahwa penyebab kegagalan utama dalam melaksanakan orientasi pelayanan publik adalah mengabaikan pentingnya biaya transaksi pelayanan. Hal ini yang menyebabkan melemahnya komitmen kerja dari pelaku organisasi dalam menjalankan pelayanan. 
Demikian juga Walters, D. (1994: 151) menambahkan bahwa kegagalan dari pelayanan publik ini disebabkan karena aparat (birokrasi) tidak menyadari adanya perubahan dan pergeseran yang terjadi dalam dinamika organisasi yang menuntut pentingnya pembiayaan transaksi pelayanan.

Berdasarkan uraian tersebut di atas, maka hal-hal yang berkaitan dengan birokrasi pemerintahan pada prinsipnya menjadikan biaya transaksi pelayanan publik sebagai bagian dari bentuk penerapan birokrasi pemerintahan. Pada prinsipnya birokrasi pemerintahan tidak efektif diterapkan bila tidak didukung oleh adanya penguatan biaya transaksi pelayanan. 


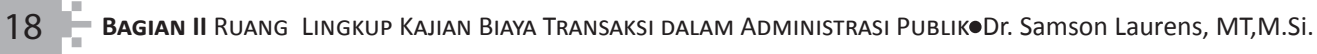




\section{BAGIAN III}

\section{VARIAN KONSEP \\ BIAYA TRANSAKSI}

\section{A. Konsep Biaya Pemerintah}

Mengkaji tentang konsep biaya pemerintah, menurut Huckman, Morgan (2008: 54) menyatakan bahwa biaya pemerintah dibedakan atas biaya rutin, biaya pembangunan, biaya kebutuhan SDM dan biaya untuk pengadaan sarana dan prasarana. Mekanisme biaya pemerintah ini diterapkan menurut pemberiannya yaitu secara langsung dan tidak langsung.

Pada instansi pemerintah penggunaan konsep biaya tidak terlepas dari pemaksanaan belanja dan pendanaan yang dikeluarkan pemerintah dalam menjalankan kelancaran roda aktivitas organisasi. Sebuah aktivitas senantiasa ditunjang oleh penggunaan biaya untuk peruntukan aktivitas rutin, pelaksanaan pembangunan, pemenuhan kebutuhan sumber daya manusia dan pengadaan sarana dan prasarana. Huckman, Morgan (2008: 68) menjelaskan hubungan aktivitas dengan kegiatan pembiayaan yang dilakukan suatu organisasi untuk mencapai tujuannya. Aktivitas membutuhkan adanya biaya rutin dalam melakukan operasional kegiatan untuk mencapai tujuan. Karenanya diperlukan adanya biaya pembangunan, biaya pengembangan SDM dan biaya pengadaan sarana dan prasarana. Semakin terpenuhi biaya yang dibutuhkan, semakin lancar roda aktivitas berjalan dalam mencapai tujuan organisasi. Lebih jelasnya digambarkan sebagai berikut.

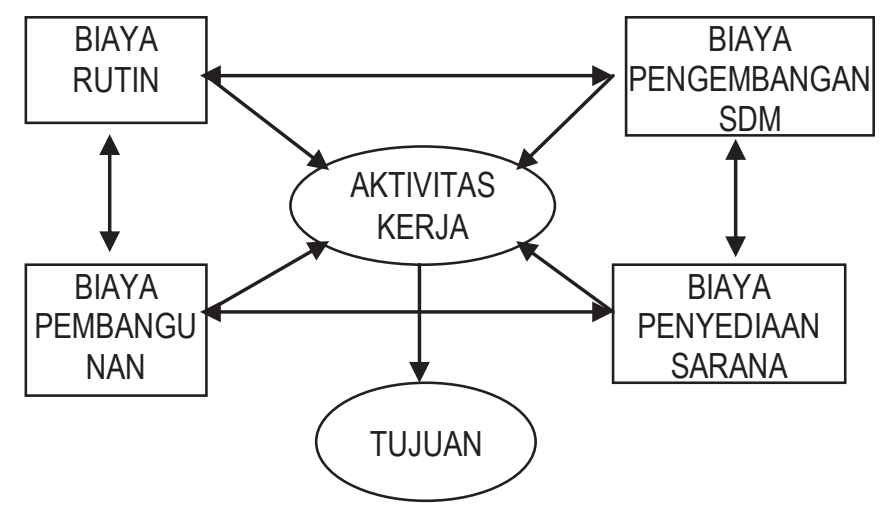

Gambar 2.1 Konsep biaya organisasi (Huckman, Morgan, 2008: 68) 
Konsep biaya organisasi di atas menjelaskan bahwa aktivitas kerja dalam suatu organisasi tidak terlepas dari adanya beban pembiayaan yang harus dikeluarkan dalam mewujudkan kelancaran aktivitas kerja dapat mencapai tujuan yang diharapkan. Biaya pembangunan SDM dan biaya pengadaan sarana prasarana mempengaruhi aktivitas kerja yang diterapkan dalam suatu organisasi untuk mencapai tujuan.

Hasil penelitian yang dilakukan oleh Alonso, Malic (2009: 15) yang mengamati faktor-faktor biaya yang mempengaruhi pembiayaan pemerintah dengan merekomendasikan bahwa faktor biaya rutin, biaya pembangunan memberikan pengaruh terhadap terlaksananya sebuah kegiatan dalam suatu organisasi. Sedangkan biaya pengembangan SDM dan ketersediaan sarana dan prasarana memberikan pengaruh terhadap kelancaran kegiatan suatu organisasi.

Berarti biaya rutin memberikan pengaruh terhadap pembiayaan pemerintah karena terdapat penilaian biaya transaksi yang mengalami peningkatan dalam setiap pembiayaan kegiatan. Biaya rutin tersebut berupa gaji, biaya pengadaan administrasi dan biaya operasional telah diposkan pembiayaannya setiap bulan untuk pelaporan tahunan, yang terkadang mengalami peningkatan. Huckman, Morgan (2008: 121) menyatakan bahwa pembiayaan suatu organisasi atau pemerintah mengalami perubahan dalam penentuan pos biaya rutin tergantung perubahan tingkat harga yang mempengaruhi biaya transaksi untuk melakukan penyusunan penyesuaian pelayanan. Berikut ditunjukkan hubungan pengaruh indikator biaya pemerintah dalam penetapan biaya transaksi untuk penyesuaian pelayanan pemerintah sebagai berikut.

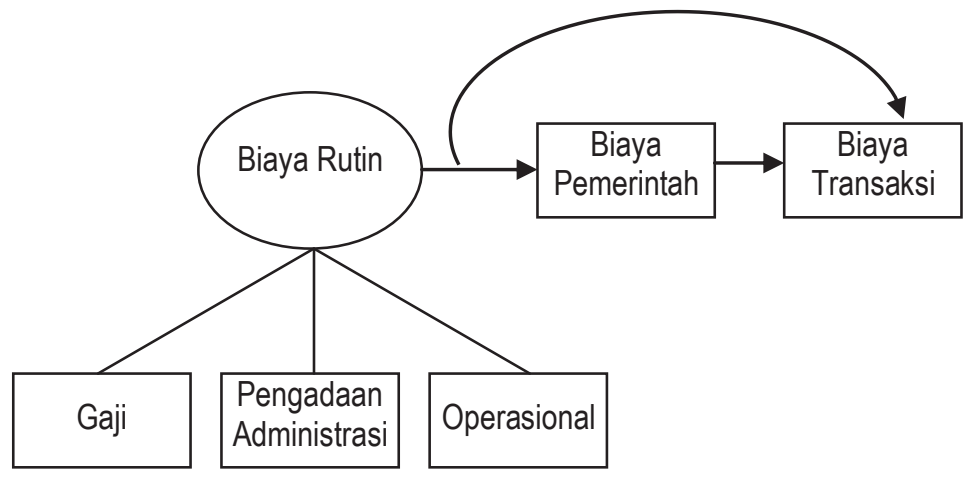

Gambar 2.2 Hubungan biaya rutin dalam biaya pemerintah untuk penetapan biaya transaksi (Huckman, Morgan, 2008: 121) 
Gambar ini menunjukkan bahwa biaya rutin diperlukan untuk pembayaran gaji, pengadaan administrasi dan kegiatan operasional sebagai biaya pemerintah melalui penetapan biaya transaksi yang jelas sesuai dengan prosedur yang berlaku.

Termasuk pula penggunaan biaya pembangunan yang dikeluarkan meliputi biaya pengadaan pembangunan, pemeliharaan/perawatan bangunan, dan pengadaan infrastruktur bangunan yang dibiayai sesuai alokasi biaya pemerintah yang penetapannya disesuaikan dengan biaya transaksi. Leonardo, Macraully (2008: 47) menyatakan besarnya biaya pembangunan dalam estimasi penganggarannya disesuaikan dengan peruntukan bangunan, jenis bangunan, dan strategi tata letak bangunan yang mengacu kepada prosedur pengadaan, pemeliharaan/ perawatan dan pengadaan infrastruktur bangunan. Berikut disajikan gambar penggunaan alokasi biaya pembangunan berdasarkan penggunaan biaya dan estimasi anggaran sebagai berikut.

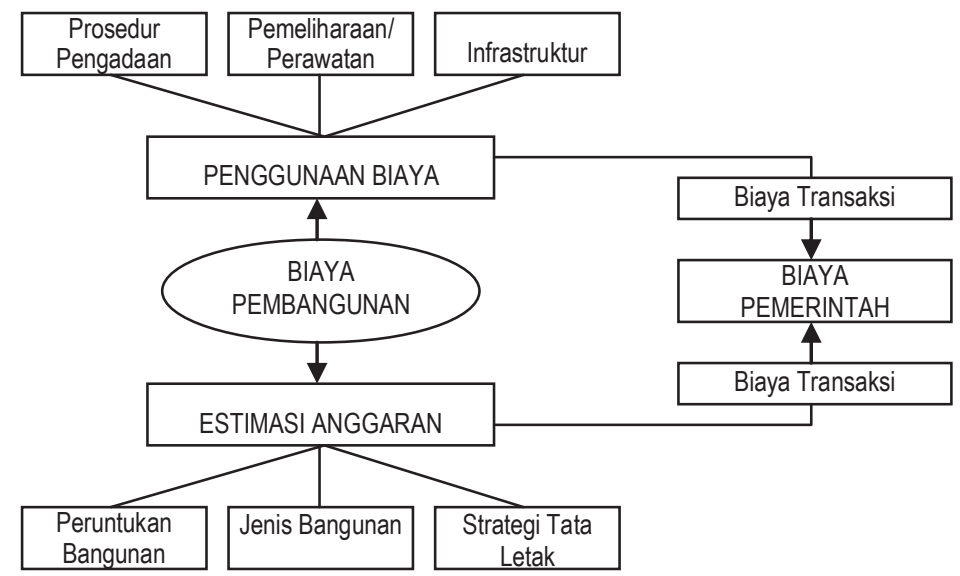

Gambar 2.3 Biaya dan estimasi anggaran untuk pembangunan (Leonardo, Macraully, 2008: 47))

Gambar di atas menunjukkan bahwa biaya transaksi ditentukan oleh penggunaan biaya dan estimasi anggaran yang digunakan untuk menentukan besarnya biaya pemerintah. Biaya pembangunan pada aktivitas pemerintah diperlukan untuk kelancaran kegiatan yang dilakukan oleh pemerintah. Besarnya biaya pembangunan ditentukan oleh penggunaan biaya dan estimasi anggaran yang sesuai dengan tingkat biaya transaksi yang terjadi.

Termasuk beban biaya pemerintah adalah biaya kebutuhan sumber daya manusia. Biaya kebutuhan sumber daya manusia ini termasuk di dalamnya adalah biaya pengembangan sumber daya manusia, biaya pemeliharaan dan pembinaan yang 
dilakukan dalam rangka meningkatkan kualitas sumber daya manusia. Besarnya biaya kebutuhan sumber daya manusia dalam suatu instansi tergantung pada biaya transaksi yang dikenakan. Seperti pengenaan biaya penganggaran diklat, biaya pemeliharaan hubungan kekerabatan kerja dan biaya pembinaan. Carlos, Samuelson (2006: 145) menyatakan biaya pemenuhan kebutuhan sumber daya manusia diperlukan dalam rangka peningkatan kualitas sumber daya manusia dalam suatu organisasi.

Carlos, Samuelson (2006: 146) hubungan biaya kebutuhan sumber daya manusia terhadap pengadaan biaya pemerintah yang sesuai biaya transaksi didasari oleh jumlah pegawai, jenis kebutuhan dan ketersediaan anggaran. Lebih jelasnya hubungan tersebut digambarkan sebagai berikut.

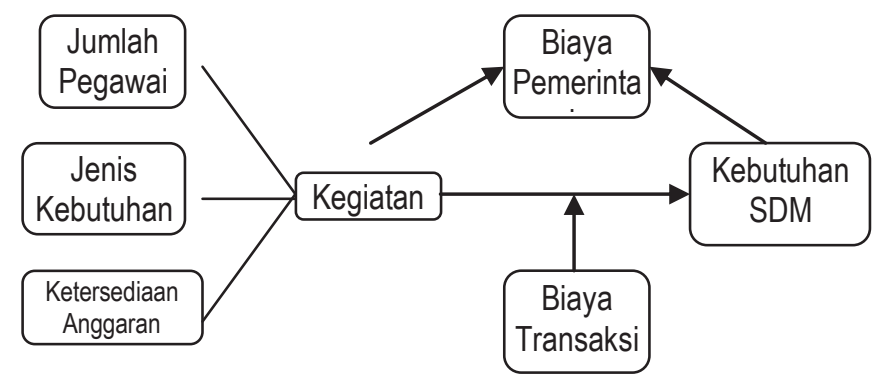

Gambar 2.4 Hubungan biaya kebutuhan SDM dan pengadaan biaya pemerintah (Carlos, Samuelson, 2006: 146)

Gambar di atas menunjukkan bahwa biaya pemerintah ditentukan berdasarkan biaya kebutuhan sumber daya manusia sesuai dengan kegiatan yang dilakukan menurut jumlah pegawai, jenis kebutuhan dan ketersediaan anggaran yang kegiatannya disesuaikan menurut biaya transaksi yang ditetapkan.

Pemerintah dalam menentukan aktivitasnya memerlukan adanya ketersediaan sarana dan prasarana yang menunjang kelancaran dari sebuah kegiatan. Karena itu, biaya administrasi diperlukan dalam pembiayaan pemerintah sesuai dengan biaya transaksi yang ditetapkan. Demmand, Knoke (2006: 95) menyatakan bahwa kelancaran suatu aktivitas ditentukan oleh ketersediaan sarana dan prasarana yang harus dibiayai sesuai dengan tingkat biaya transaksi yang diperlukan dalam menjamin kelancaran suatu proses kegiatan yang dilakukan pemerintah. Berikut gambar mengenai penentuan biaya sarana dan prasarana berdasarkan biaya transaksi dari kegiatan pembiayaan pemerintah. 


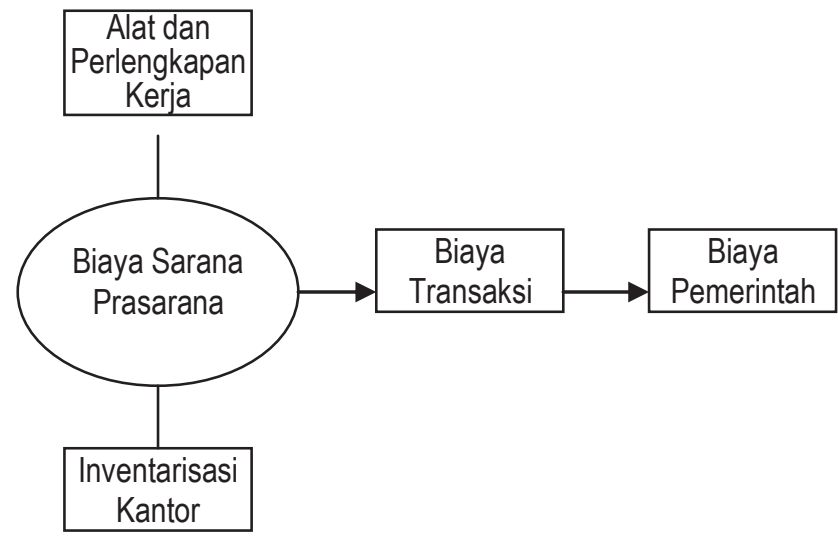

Gambar 2.5 Penentuan biaya sarana dan prasarana berdasarkan biaya transaksi dari kegiatan pembiayaan pemerintah (Demmand, Knoke, 2006: 96)

Gambar di atas menunjukkan biaya sarana dan prasarana yang dikeluarkan digunakan untuk biaya alat dan perlengkapan kerja serta pengadaan inventarisasi kantor, berdasarkan biaya transaksi yang telah ditetapkan sebagai penetapan biaya pemerintah.

Berdasarkan uraian-uraian tersebut di atas, diketahui bahwa biaya pemerintah yang dikenakan biaya transaksi yaitu biaya rutin, biaya pembangunan, biaya kebutuhan SDM dan biaya sarana dan prasarana kerja yang mendukung kegiatan pemerintah. Biaya transaksi yang dikenakan sesuai dengan tingkat pembiayaan dan kebutuhan yang diperlukan untuk kelancaran suatu kegiatan yang sesuai dengan standar pelayanan.

\section{B. Konsep Biaya Pasar}

Pengertian konsep biaya pasar yang dimaksud adalah kegiatan pembiayaan yang dikeluarkan untuk pemenuhan kebutuhan pelayanan sesuai dengan mekanisme pasar. Lamdant, WG. Guci (2007: 49) menyatakan bahwa biaya pasar adalah biaya mekanisme yang terjadi atas dasar negosiasi telah dimonitoring mengalami pertukaran dan dapat di evaluasi untuk menciptakan biaya transaksi yang menentukan manfaat dari suatu kegiatan yang dilakukan.

Berarti biaya pasar dari suatu organisasi diartikan sebagai sebuah biaya yang berpatokan pada mekanisme pasar. Karakteristik dari mekanisme pasar selalu ditandai oleh empat hal: (1) penetapan biaya selalu diawali dengan negosiasi, (2) dalam 
penetapan biaya aspek monitoring diperlukan untuk mengetahui nilai biaya, (3) aspek pertukaran diperlukan dalam menentukan biaya dari suatu perubahan harga, (4) mengevaluasi biaya penetapan yang sesuai dengan biaya peruntukan. Keempat unsur ini penting dalam menentukan biaya transaksi dalam suatu kegiatan organisasi.

Gareth R, Jones (2004: 48) memberikan suatu pandangan tentang teori market cost (biaya pasar) dengan mengasumsikan bahwa biaya transaksi dalam mekanisme pasar adalah sebuah bangunan segitiga emas yang saling menopang dalam mencapai suatu motif pembiayaan organisasi. Unsur yang saling menopang tersebut adalah negosiasi, monitoring, pertukaran dan evaluasi. Lebih jelasnya ditunjukkan pada gambar di bawah ini.

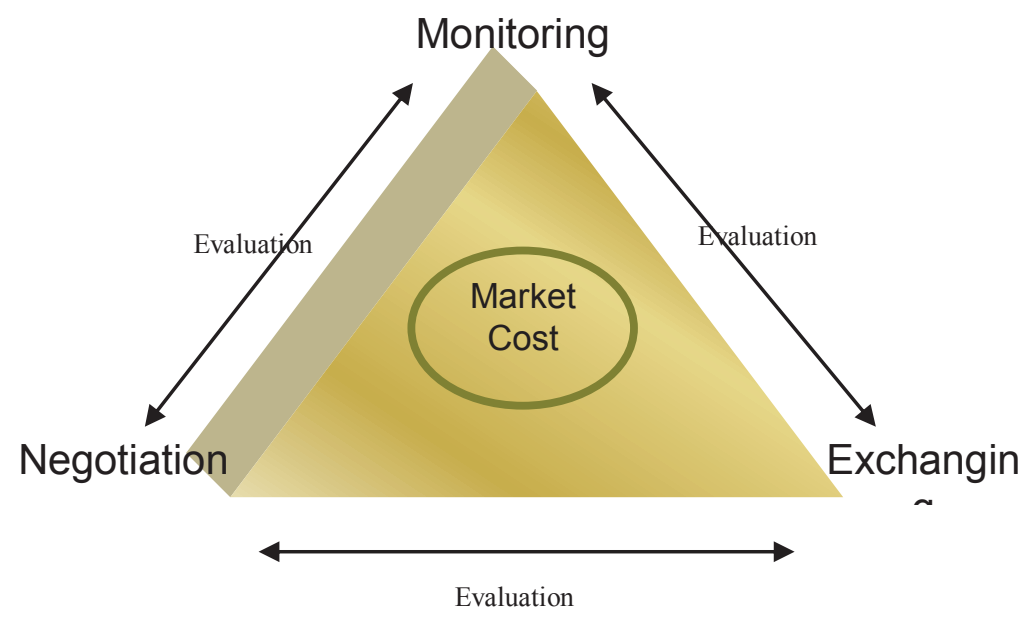

Gambar 2.6 Segitiga emas kebijakan (Gareth R. Jones, 2004: 48)

Pandangan tentang teori market cost dalam suatu organisasi memandang bahwa suatu tujuan organisasi membutuhkan adanya suatu upaya negosiasi dalam penggunaan biaya yang harus diawasi atau dimonitoring dalam pelaksanaannya, sehingga pertukaran antara pelayanan yang diterima dan biaya yang dikenakan memberikan hasil tercapainya keseimbangan pelayanan yang diistilahkan service balanced, yang selanjutnya dilakukan evaluasi keseluruhan unsur biaya transaksi. Inilah yang menjadi dasar indikator dalam menentukan biaya pasar dalam mempengaruhi biaya transaksi dan kesesuaian pelayanan publik.

Pentingnya market cost dalam suatu organisasi tidak dapat dilepaskan dari adanya aspek negosiasi yaitu sebuah hubungan keterkaitan kerjasama dari kepentingan dalam memperoleh keuntungan atas transaksi cost yang dilakukan. Negosiasi berperan penting untuk menentukan kesepakatan atas pembiayaan yang ditetapkan menurut 
kesepakatan yang saling membutuhkan. Herlind, Harold (2006: 132) menyatakan negotiation cost berperan penting membuat kesepakatan dalam bekerjasama dan memberikan keuntungan atas berbagai kepentingan pembiayaan dari masing-masing pihak dalam melakukan negosiasi.

Landasan dasar menurut Herlind, Harold (2006: 133) dari suatu biaya negosiasi didasari oleh tiga aspek yang berperan penting dalam menentukan kelancaran suatu pembiayaan berdasarkan mekanisme pasar yaitu: 1) negosiasi dalam kerjasama, 2) negosiasi dalam berbagai kepentingan, dan 3) negosiasi dalam keberuntungan. Berikut digambarkan aspek negosiasi dalam pembiayaan mekanisme pasar di bawah ini:

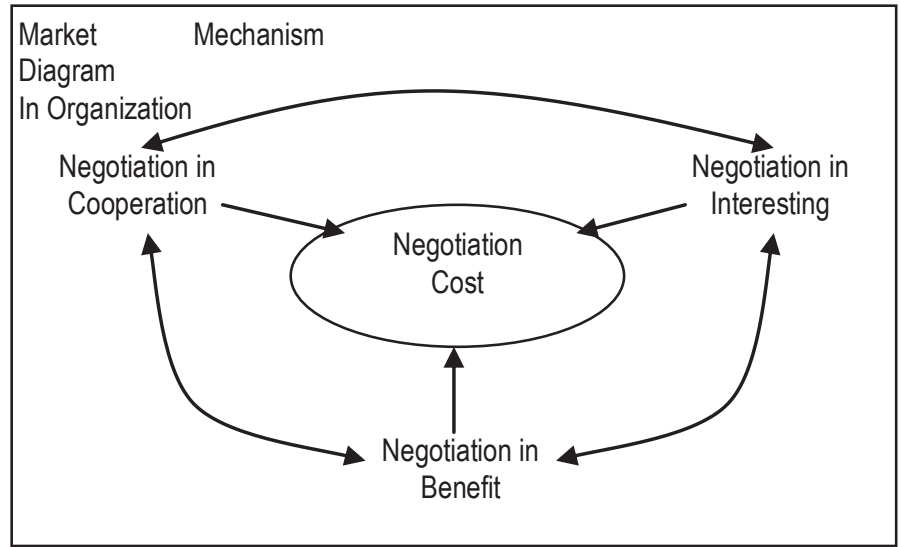

Gambar 2.7 Aspek biaya negosiasi dalam pembiayaan mekanisme pasar (Herlind, Harold, 2006: 133)

Gambar di atas menunjukkan bahwa dalam suatu organisasi ditemukan adanya mekanisme pasar dalam menetapkan suatu pembiayaan yang harus dinegosiasikan. Wujud negosiasi yang diterapkan berdasarkan negosiasi dalam kerjasama, negosiasi dalam kepentingan dan negosiasi dalam keuntungan. Ketiga aspek ini saling berkaitan dalam mempengaruhi biaya mekanisme pasar terhadap biaya transaksi dan penyesuaian pelayanan.

Menghasilkan suatu pembiayaan diperlukan adanya aspek pengawasan atau monitoring terhadap biaya-biaya yang dikeluarkan dalam mekanisme pasar. Biaya monitoring tersebut berupa biaya pengendalian internal dan eksternal. Roberts, Edward B. (2002: 59) menyatakan biaya mekanisme pasar dalam penentuan biaya transaksi sangat ditentukan oleh penetapan biaya monitoring internal yaitu kebijakan-kebijakan yang berkaitan dengan pembiayaan dan penganggaran yang diusulkan dan biaya 
monitoring eksternal yaitu biaya kegiatan yang berkaitan dengan pengembangan organisasi.

Roberts, Edward B (2002: 61) menyatakan mekanisme pasar dalam penetapan besarnya biaya transaksi dipengaruhi oleh adanya penetapan biaya monitoring internal dan eksternal. Biaya monitoring tersebut secara langsung menentukan biaya mekanisme pasar yang mempengaruhi biaya transaksi dalam melakukan aktivitas pembiayan organisasi.

Sasongko, Hermanto (2006: 195) menyatakan mekanisme pasar mempengaruhi biaya transaksi sesuai dengan tingkat ekspektasi monitoring yang diterapkan dalam suatu organisasi. Ekspektasi monitoring tersebut meliputi internal dan eksternal. Monitoring internal yang mempengaruhi biaya transaksi yaitu prosedur administrasi dan keuangan organisasi. Sedangkan monitoring eksternal ditentukan oleh kerjasama dan komunikasi dalam menetapkan pembiayaan. Berikut gambar yang terkait dengan biaya pasar dalam menentukan biaya transaksi dilihat dari pengaruh biaya monitoring sesuai mekanisme pasar:

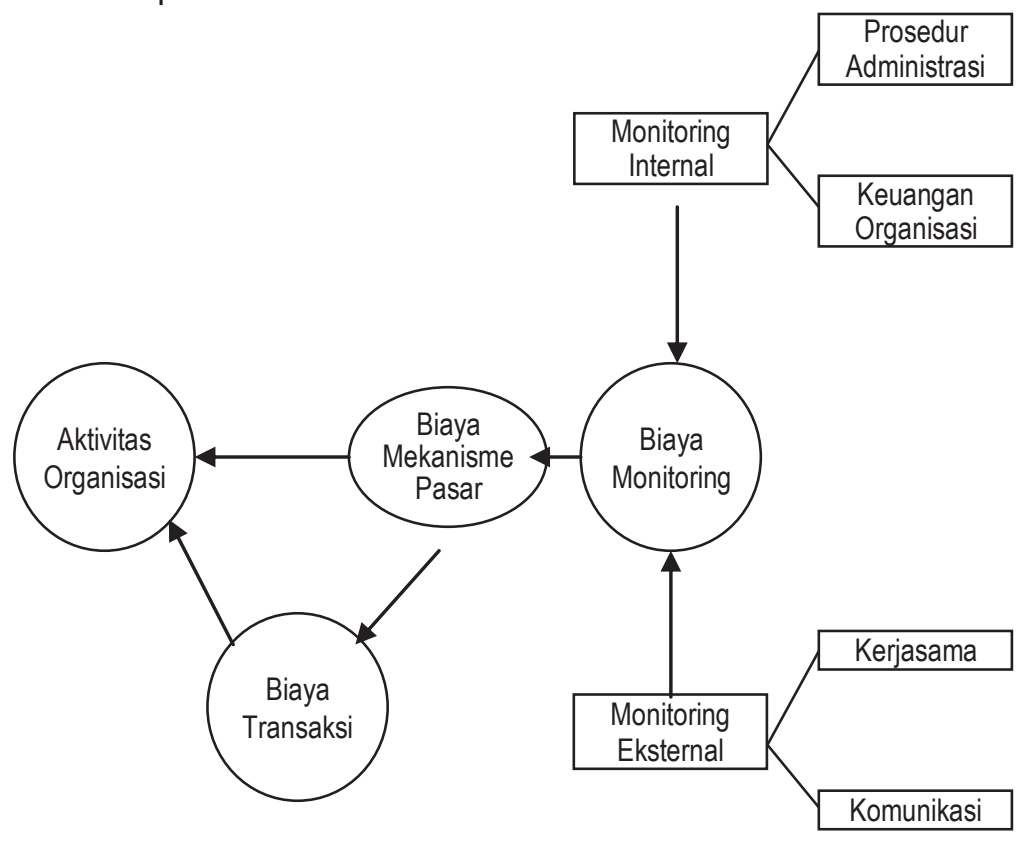

Gambar 2.8 Biaya transaksi dilihat dari pengaruh biaya monitoring sesuai mekanisme pasar (Sasongko, Hermanto, 2006: 196)

Gambar di atas, menunjukkan bahwa andil prosedur administrasi dan keuangan merupakan obyek monitoring internal, kerjasama dan komunikasi menjadi obyek 
monitoring eksternal yang merupakan bagian dari penentuan biaya monitoring yang sesuai dengan proporsi biaya mekanisme pasar dalam pembiayaan aktivitas organisasi yang dipengaruhi oleh adanya biaya transaksi. Biaya mekanisme pasar dapat dilakukan sesuai dengan kebutuhan aktivitas organisasi, namun perubahan-perubahan aktivitas biaya mekanisme pasar mempengaruhi biaya transaksi untuk menghasilkan penetapan biaya bagi setiap aktivitas organisasi.

Biaya mekanisme pasar dalam pembiayaan suatu instansi pemerintah, terjadi berbagai perubahan-perubahan sesuai dengan tingkat perputaran pembiayaan yang terjadi. Biaya perubahan dilakukan biasanya mengalami peningkatan biaya transaksi dari perencanaan standar biayaan yang ditetapkan. Sasongko, Hermanto (2006: 122) menyatakan biaya pertukaran merupakan biaya permintaan penambahan atau pengurangan dari alokasi pembiayaan yang telah ditetapkan sebelumnya untuk direalisasikan dalam pembiayaan aktivitas kegiatan pemerintah.

Memahami pentingnya biaya pertukaran ini tidak terlepas dari adanya alokasi prioritas dari suatu kegiatan yang dapat dilakukan pertukaran sesuai dengan sifat perubahan kegiatan yang telah ditetapkan dan dilakukan pertukaran pada suatu ketentuan yang telah diusulkan. Sasongko, Hermanto (2006: 123) menyatakan biaya pertukaran merupakan bagian dari pembiayaan mekanisme pasar untuk menentukan besarnya biaya pertukaran yang dilakukan atas aktivitas alokasi pembiayaan yang dilakukan penggantian sesuai dengan tingkat prosedur perubahan yang mempengaruhi biaya transaksi dari suatu aktivitas. Berikut digambarkan biaya pertukaran di bawah ini:

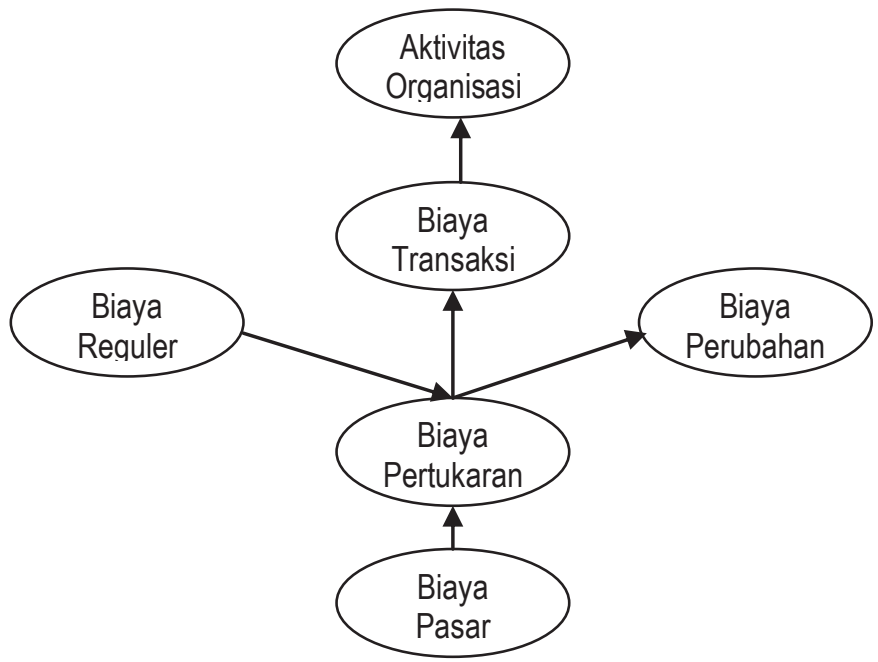

Gambar 2.9 Biaya pertukaran (Sasongko, Hermanto, 2006: 195) 
Gambar di atas menunjukkan bahwa biaya pertukaran berperan penting dalam menentukan penetapan biaya transaksi terhadap penggunaan biaya aktivitas organisasi. Biaya pertukaran ini ditentukan oleh besarnya kontribusi biaya reguler yang dialokasikan setiap tahun dan biaya perubahan. Biaya pertukaran yang diperlukan dalam menopang biaya pasar dalam mempengaruhi besarnya biaya transaksi yang digunakan dalam penyesuaian layanan yang diterapkan.

Menentukan pembiayaan yang digunakan oleh instansi pemerintah untuk menentukan biaya pasar, efektif atau tidaknya suatu pembiayaan kegiatan organisasi, maka biaya pasar perlu disesuaikan berdasarkan biaya evaluasi. Huckman, Morgan (2008: 185) menyatakan biaya pasar berperan penting dalam menentukan biaya transaksi berdasarkan pertimbangan pengevaluasian biaya. Aspek penting yang perlu dievaluasi dari biaya pasar adalah jumlah aset atau inventarisasi, pengadaan, perbaikan, penyelesaian dan pelaporan dari setiap kegiatan yang mempengaruhi biaya transaksi kegiatan.

Sasongko, Hermanto (2006: 163) menjelaskan biaya pasar merupakan biaya yang dikeluarkan untuk membeli barang/jasa sesuai dengan standar pasar dengan kebutuhan kegiatan yang dibiayai. Aspek penting dari pembiayaan ini harus ditunjukkan evaluasi pembiayaan berdasarkan kegiatan inventaris, pengadaan, perbaikan, penyelesaian dan pelaporan untuk mengetahui penggunaan biaya pasar yang dapat dievaluasi dalam menentukan pembiayaan transaksi lebih jelasnya ditunjukkan gambar sebagai berikut.

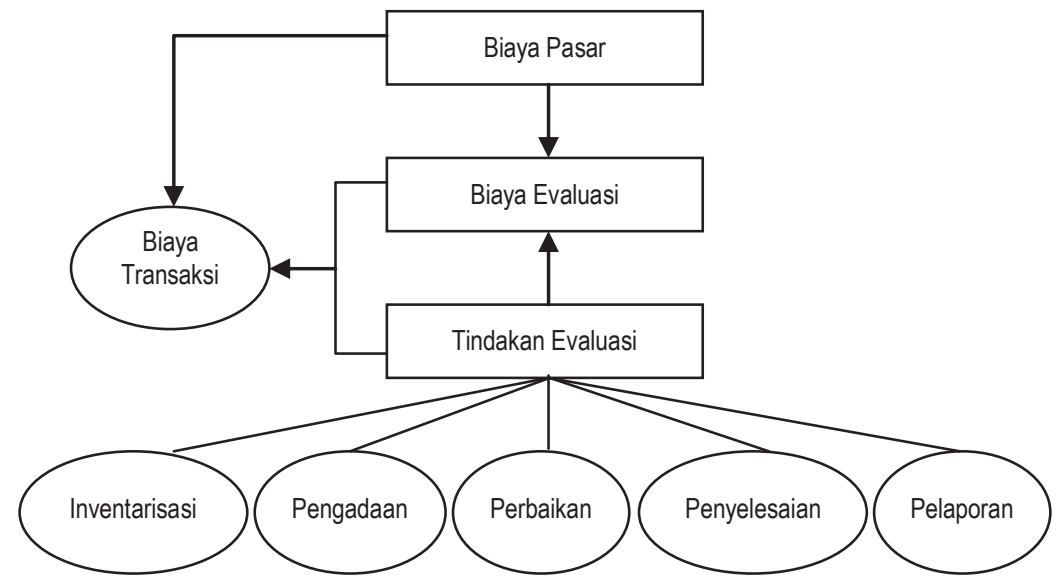

Gambar 2.10 Biaya evaluasi (Sasongko, Hermanto, 2006: 163)

Gambar di atas menunjukkan bahwa biaa transaksi dalam suatu organisasi dipengaruhi oleh biaya pasar berdasarkan biaya evaluasi dan tindakan evaluasi. 
Tindakan evaluasi ini dalam suatu organisasi mengevaluasi setiap kegiatan yang berkaitan dengan inventarisasi, pengadaan, perbaikan, penyelesaian dan pelaporan yang berkaitan dengan sumber pembiayaan yang digunakan.

Berdasarkan uraian tentang biaya pasar yang ditentukan dari biaya negosiasi, biaya monitoring, biaya pertukaran dan biaya evaluasi secara langsung maupun tidak langsung memberikan pengaruh terhadap penentuan besarnya biaya transaksi yang digunakan untuk kegiatan penyesuaian pelayanan dalam suatu organisasi.

\section{Biaya Transaksi}

Pendekatan biaya transaksi, sebagaimana dikembangkan oleh banyak pakar seperti Williamson dan Ouchi, memfokuskan bagaimana karakteristik suatu transaksi berpengaruh terhadap biaya untuk transaksi tersebut baik melalui pasar, birokrasi, maupun melalui organisasi lainnya. Suatu transaksi terjadi ketika "a good or service is transferred across a technologically separable interface" (Williamson, Olivier E., 1996). Menurut Supriyono (2000: 16), biaya adalah harga perolehan yang dikorbankan atau digunakan dalam rangka memperoleh penghasilan atau revenue yang akan dipakai sebagai pengurang penghasilan. Biaya transaksi mencakup ongkos untuk mengumpulkan dan memproses informasi yang diperlukan untuk melakukan transaksi, mencapai keputusan, menegosiasikan kontrak, dan melaksanakan kontrak tersebut sesuai hukum kontrak. Pendekatan biaya transaksi menegaskan bahwa bentuk organisasi atau "governance structure" yang meminimalkan biaya transaksi untuk suatu kegiatan akan mempunyai keunggulan kompetitif dan cenderung mendominasi kegiatan tersebut. Kelemahan pendekatan biaya transaksi adalah kecenderungannya untuk menganggap struktur biaya sebagai hal yang baku, mengabaikan kemampuan organisasi bentuk lainnya untuk mengubah distribusi hak milik dan definisi "efisiensi" (Bromley, Daniel W, 1982).

Untuk memahami biaya transaksi (transaction cost) mengacu pada teori informasi asimetri (asymmetric information), teori perilaku peluang (opportunity behavior) dan teori nilai ekonomis efisiensi (efficiency economic value). Ketiga teori ini dijelaskan berdasarkan pandangan para ahli sebagai berikut

a. Teori Asymmetric Information

Teori asymmetric information adalah sebuah teori yang menjelaskan pentingnya eksistensi informasi dalam kegiatan pelayanan yang menimbulkan adanya pelayanan yang berdampak pada kegagalan pasar 
dengan biaya transaksi yang digunakan lebih besar dari manfaatnya. Pada intinya asymmetric information adalah sebuah teori pendekatan untuk menjelaskan pentingnya suatu kegiatan pelayanan yang memerlukan pembiayaan (Webley, P., 2005: 43).

Menurut Mahadarma (2012), Informasi asimetri adalah suatu kondisi di mana satu pihak memiliki satu (atau lebih) informasi dari yang lain kemudian menciptakan ketidakseimbangan kekuasaan (atau pengaruh) dalam transaksi yang mempengaruhi hasil pengambilan keputusan (asymmetric information - one party has better information than the other party with worse information also suffers from imperfect information). Istilah asimetri informasi lebih dikenal dalam ilmu ekonomi, namun tidak jarang juga ditemui dalam istilah ilmu politik dalam konteks Moral Hazard yang dipahami sebagai dilema principal-agent.

Kajian ilmu administrasi menjadikan teori asymmetric information sebagai kajian untuk melihat adanya hubungan yang saling terkait antara permintaan pelayanan (service demand) dengan penawaran pelayanan (service supply) untuk menghasilkan keseimbangan (equilibrium) pelayanan yang menguntungkan antara pemerintah dan publik (Tietz, 2002: 121).

Konsepsi teori asymmetric information merupakan suatu kegiatan secara langsung mengenai proses informasi yang dilakukan oleh pemerintah kepada publik tanpa mengabaikan pentingnya informasi sebagai sebuah peluang untuk memenuhi kepuasan publik. Atas dasar tersebut maka biaya transaksi suatu pelayanan tergantung pada muatan informasi yang diberikan oleh pihak pengambil kebijakan (Thaler, 2003: 206).

Dalam kegiatan pelayanan pemerintah terhadap publik, ditemukan adanya kegiatan-kegiatan yang membutuhkan biaya transaksi. Kegiatan transaksi pelayanan bertumpu kepada adanya informasi asimetri yang diberikan oleh pemerintah dan dibutuhkan oleh publik. Adanya kepentingan dua belah pihak menimbulkan efek permintaan dan efek penawaran untuk menghasilkan keuntungan pembiayaan yang dapat digunakan secara operasional dalam pencapaian tujuan organisasi dan kepuasan publik (Todd, 2005: 223).

Ini berarti, biaya transaksi pelayanan menjadikan teori asymmetric information sebagai bagian penting di dalam menguraikan unsur-unsur 
yang berperan penting dalam rantai biaya transaksi. Semakin bagus pelayanan informasi yang diberikan oleh pemerintah, semakin berperan penting biaya transaksi yang dilakukan untuk memenuhi kepuasan publik.

\section{b. Teori Opportunity Behavior}

Teori opportunity behavior pada prinsipnya adalah teori yang mengkaji perilaku birokrasi pemerintah di dalam mengembangkan peluang kerja yang prospektif dalam melayani kebutuhan publik. Teori ini diperkenalkan oleh Webley, P. (2005: 155) keberhasilan suatu biaya transaksi dalam organisasi ditentukan dari perilaku birokrasi yang mencari peluang untuk memperoleh keuntungan. Ini berarti peluang menjadi penting dari perilaku pelaksana untuk menghasilkan pelayanan terbaik yang dengan sendirinya publik akan membayar dengan biaya transaksi yang sesuai tanpa menimbulkan adanya apresiasi yang negatif.

Melaksanakan tugas kegiatan pelayanan tidak terlepas dari adanya biaya transaksi, karena itu sebuah organisasi berupaya mengembangkan perilaku aparat di dalam menerapkan teori opportunity behavior sebagai langkah kongkrit untuk memperbaiki pelayanan dalam menghasilkan biaya transaksi yang optimal (Traub dalam Tietz (2002: 161).

Keberhasilan suatu organisasi pada prinsipnya ditentukan oleh adanya opportunistic behavior dari setiap aparat pelayanan. Tversky dalam Tietz (2002: 162) perilaku dan peluang merupakan akses penting dalam memperbaiki biaya transaksi dari suatu kegiatan pelayanan untuk mencapai kepuasan. Inti dari opportunity behavior adalah adanya suatu kondisi yang diemban oleh pekerja dalam memperbaiki akses dan citra aparat dalam memberikan pelayanan untuk menghasilkan biaya transaksi yang menguntungkan dan memberikan nilai kepuasan pada publik.

Organisasi dalam upaya memperoleh keuntungan optimal, berupaya memperbaiki opportunistic behavior sebagai penyikapan untuk menghasilkan optimalisasi keuntungan dengan meminimalkan biaya yang dikenakan. Tietz (2002: 163) memformulasikan opportunistic behavior sama dengan benefit optimalization (keuntungan optimal) dikurangi minimization cost (minimalisasi biaya) dengan rumus sebagai berikut. 


\section{$\mathrm{OB}=\mathrm{BO}-\mathrm{MC}$}

Dari sudut pandang kebijakan publik, opportunistic behavior sangat diperlukan dalam membuat suatu formulasi kebijakan yang berkenaan dengan perilaku peluang di dalam menentukan besarnya transaksi biaya yang sesuai dengan tingkat kebutuhan informasi dan nilai ekonomis yang dibutuhkan oleh organisasi dalam memberikan pelayanan kepada publik.

Uraian ini menjadi kajian dalam mencermati pentingnya biaya transaksi dilihat dari aspek opportunity behavior yang harus disikapi oleh pengambil kebijakan publik untuk mencapai keberhasilan tujuan. Keberhasilan merupakan dinamika dari suatu perubahan akan kebutuhan dan nilai tambah yang dibutuhkan dalam kegiatan organisasi.

c. Teori Efficiency Economic Value

Teori efficiency economic value atau teori nilai ekonomi efisiensi merupakan sebuah teori untuk melihat tingkat pemanfaatan suatu kegiatan biaya transaksi dinilai dari aspek ekonomi berupa untung atau rugi. Ritzer, George, Gullbart, Michael (2005: 215) menyatakan keuntungan suatu organisasi tergantung pada efisiensi nilai ekonomis yang digunakan untuk memprediksi besarnya keuntungan dan kerugian yang ditimbulkan dari kegiatan transaksi pelayanan.

Unsur-unsur penting dari suatu tahapan efisiensi nilai ekonomi adalah unsur transaksi, manfaat, keuntungan, kerugian dan kepentingan. Unsur inilah yang melahirkan adanya proposisi dari beberapa pakar dalam menyikapi pentingnya efisiensi nilai ekonomi sebagai berikut:

1) Semakin banyak transaksi pelayanan yang terjadi dalam suatu organisasi semakin memberikan nilai tambah ekonomis bagi organisasi memperoleh keuntungan (Viscusi, WK. 2003: 79).

2) Semakin banyak manfaat dari transaksi yang diterapkan, upaya minimalisasi biaya semakin besar nilai ekonomis dilakukan oleh organisasi (Wittman, DA. 2004: 246).

3) Biaya transaksi yang tinggi dibarengi dengan pelayanan yang memuaskan menjadi nilai tambah bagi organisasi untuk maju dan berkembang (Birl, Higgins, 2003: 195). 
4) Meminimalisasi biaya operasional dan meningkatkan biaya transaksi akan mempengaruhi tingkat kepuasan pelayanan (Yates, Crozier, 2001: 165).

5) Adanya kepentingan dalam permintaan dan penawaran menjadi peluang dalam menentukan besarnya biaya transaksi yang memiliki nilai tambah ekonomis (Huber, Marcel, 2007: 187).

Pandangan-pandangan ini menjadi dasar untuk menilai pentingnya analisis nilai ekonomi efisiensi dari suatu kegiatan biaya transaksi pelayanan untuk mencapai sebuah tujuan dan memenuhi kepuasan publik.

\section{Biaya Transaksi Pemerintah}

Setiap kegiatan pemerintah membutuhkan biaya. Setiap organisasi pemerintahan dalam memberikan pelayanan selalu melakukan transaksi dalam berbagai jenis pelayanan. Gareth R, Jones (2004: 76) menyatakan bahwa biaya transaksi pemerintah merupakan modal dasar suatu organisasi dalam mencapai tujuannya.

Mustahil suatu organisasi akan maju dan berkembang jika tidak ditunjang oleh kegiatan pembiayaan berupa biaya transaksi. Biaya transaksi mempunyai peranan utama dalam menjalankan aktivitas pelayanan. Gareth R, Jones (2004: 77) pada prinsipnya teori biaya transaksi bertujuan untuk meminimalkan biaya dari kegiatan penyesuaian pelayanan untuk menghasilkan kegiatan yang efektif, efisien dan ekonomis. Ini berarti, suatu organisasi yang maju dan berkembang selalu bertumpu pada terpenuhinya pemenuhan kebutuhan organisasi. Kebutuhan organisasi bertumpu kepada pembiayaan dalam organisasi. Nearly (2003: 251) kebutuhan pembiayaan merupakan hal yang prinsip di dalam menjaga kelangsungan hidup organisasi baik berupa biaya informasi, biaya teknologi, biaya administrasi dan biaya operasional.

Matthews, Jorgy (2005: 45) menyatakan bahwa biaya transaksi berperan penting dalam meningkatkan penyesuaian pelayanan yang dilakukan pemerintah melalui penyediaan biaya informasi, biaya teknologi, biaya administrasi dan biaya operasional. Pengadaan peruntukan biaya tersebut tidak terlepas dari adanya biaya transaksi antara pihak provider dan client. Hubungan biaya transaksi pemerintah dengan usulan peruntukan biaya yang dianggarkan. Alokasi pembiayaan pemerintah yang menunjang kegiatan layanan selalu diprioritaskan usulan peningkatan biaya informasi, biaya teknologi, biaya administrasi dan biaya operasional. Moey dalam Matthews, Jorgy (2005: 46) menyatakan bahwa biaya pemerintah berperan penting dalam kegiatan layanan. Biaya transaksi terdiri atas biaya informasi, biaya teknologi, biaya administrasi 
dan biaya operasional memberi kontribusi dalam biaya pemerintah. Berikut gambar kontribusi biaya transaksi untuk meningkatkan alokasi biaya pemerintah.

Transaction Cost

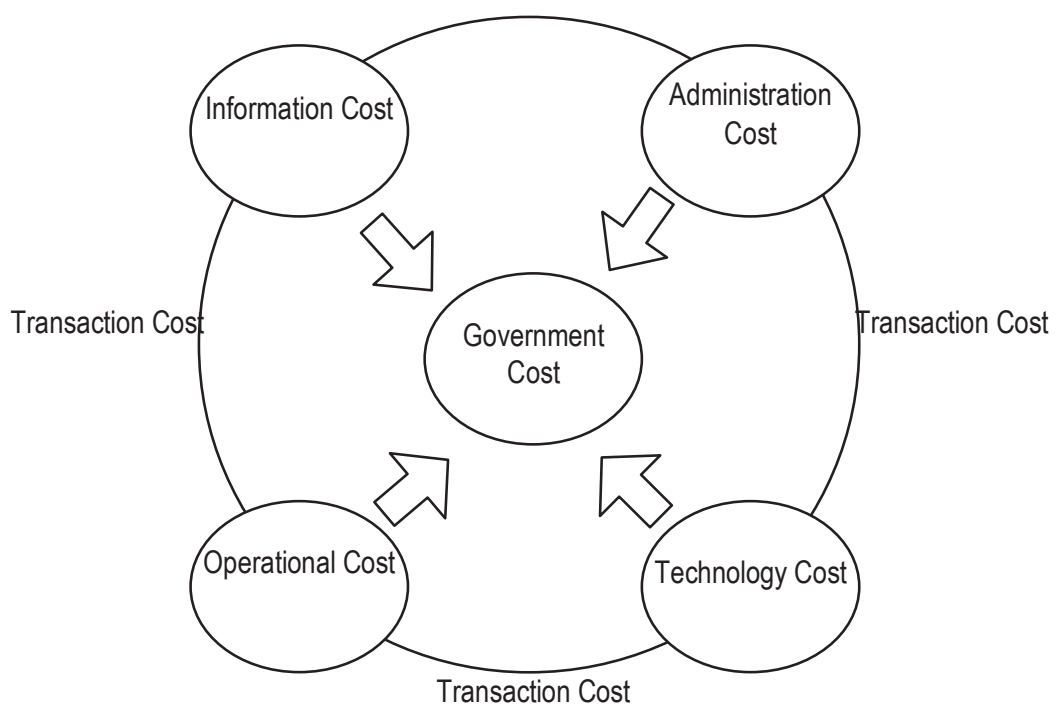

Gambar 2.11 Kontribusi biaya transaksi untuk alokasi biaya pemerintah (Moey dalam Matthews, Jorgy (2005: 46))

Gambar di atas menunjukkan siklus pertimbangan dalam menentukan biaya transaksi itu terdiri dari biaya informasi, administrasi, operasional dan teknologi. Pertimbangan ini sangat besar pengaruhnya dalam melakukan sebuah penetapan penyesuaian pelayanan. Diakui bahwa suatu organisasi dalam penerapannya selalu membutuhkan biaya transaksi. Karel, Lann (2006: 103) menyatakan biaya transaksi pemerintah adalah kebutuhan organisasi untuk mencapai tujuannya. Ini berarti, keberadaan biaya transaksi dalam berbagai kegiatan pelayanan membutuhkan adanya aspek pembiayaan informasi, administrasi, operasional dan teknologi.

Pandangan Karel mempunyai korelasi yang erat dari apa yang dikemukakan oleh Gareth R, Jones (2004: 90) yang menyatakan bahwa biaya transaksi adalah biaya yang berperan penting dalam menciptakan peluang organisasi untuk memberikan pelayanan yang terbaik. Ini berarti esensi dari biaya dalam berbagai kegiatan pelayanan pembiayaan atau penganggaran berperan penting dalam memperlancar pencapaian suatu tujuan organisasi. 
Norman, Davis (2004: 59) memberikan suatu gambaran diagram tentang biaya transaksi pelayanan yang diterapkan dalam suatu organisasi. Sebuah asumsi bahwa biaya transaksi ditentukan oleh adanya hubungan yang saling berkorelasi antara biaya informasi, biaya teknologi, biaya administrasi dan biaya operasional yang digunakan untuk menciptakan adanya kelayakan atau kesesuaian biaya yang diterapkan dalam pelayanan. Hubungan ini digambarkan dalam sebuah diagram antara pelayanan pemerintah yang diberikan kepada unit pemerintah dan kemampuan unit pemerintah dalam menerima pelayanan. Keempat unsur dari biaya transaksi pelayanan yang dicapai pada prinsipnya mempunyai arah yang sama dalam penetapan pembiayaan transaksi pelayanan yang diterapkan oleh organisasi. Lebih jelasnya ditunjukkan pada gambar di bawah ini:

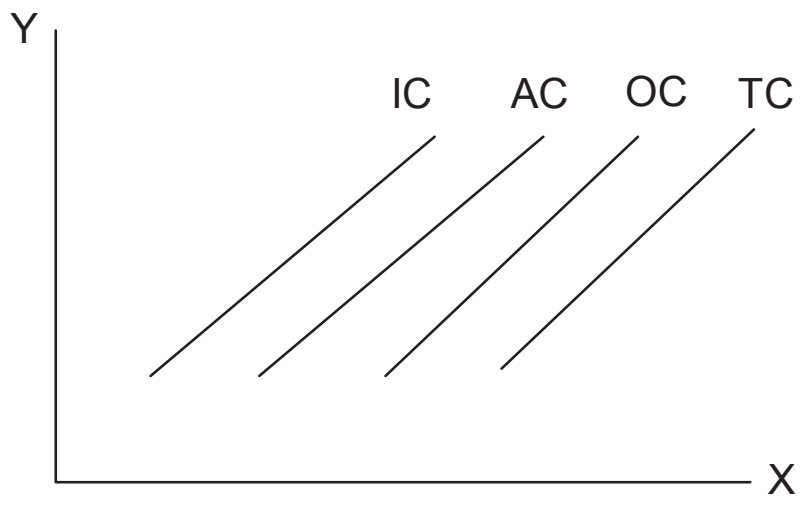

Gambar 2.12 Diagram unsur pencapaian biaya transaksi pelayanan (Norman, Davis, 2004: 60)

Keterangan:

$\mathrm{Y}=$ Biaya Transaksi

$\mathrm{X} \quad=$ Unit Pemerintah

IC = Biaya Informasi (Information Cost)

$\mathrm{AC}=$ Biaya Administrasi (Administration Cost)

$\mathrm{OC} \quad=$ Biaya Operasional (Operational Cost)

TC = Biaya Teknologi (Technology Cost)

Gambar ini menjelaskan bahwa suatu organisasi bertujuan untuk meminimalkan pembiayaannya apabila anggaran transaksi tidak tepat sasaran, dengan asumsi menghindari adanya biaya yang berlebihan. Untuk mengatasi agar pembiayaan tidak mengalami surplus dan less, maka organisasi membutuhkan keseimbangan biaya transaksi pelayanan dengan tujuan agar proses pelayanan terus survive. Upaya yang harus diperbaiki adalah mempertimbangkan penggunaan biaya informasi, biaya 
teknologi, biaya administrasi dan biaya operasional, untuk digunakan sesuai dengan kesesuaian pelayanan organisasi.

Seperti halnya dalam pandangan Gareth R, Jones (2004: 95) bahwa biaya transaksi dalam suatu organisasi dikelola dengan baik melalui tahapan efisiensi, efektivitas dan ekonomis dalam pembiayaan.

Menurut Perpres No. 54 tahun 2010 bahwa efisien berarti pengadaan barang/jasa harus diusahakan dengan menggunakan dana dan daya yang minimum untuk mencapai kualitas dan sasaran dalam waktu yang ditetapkan atau menggunakan dana yang telah ditetapkan untuk mencapai hasil dan sasaran dengan kualitas yang maksimum, sedangkan efektif, berarti pengadaan barang/jasa harus sesuai dengan kebutuhan dan sasaran yang telah ditetapkan serta memberikan manfaat yang sebesarbesarnya.

Biaya transaksi yang tinggi yang tidak sesuai dengan kepuasan akan berdampak rendahnya mutu layanan.

Perlu diketahui dalam kegiatan pelayanan yang memerlukan biaya transaksi, diketahui adanya sumber biaya transaksi yang berasal dari kombinasi biaya peruntukan manusia dan biaya peruntukan lingkungan kerja. Gareth R, Jones (2004: 98) biaya peruntukan manusia meliputi adanya kondisi lingkungan tertentu, pencapaian peluang yang diharapkan dan risiko kerja yang membutuhkan biaya transaksi pelayanan. Sementara biaya peruntukan lingkungan kerja membutuhkan adanya keterikatan rasionalitas dalam penggunaan biaya, mempertimbangkan jumlah yang kecil dalam pengeluaran biaya dan senantiasa membiayai aset-aset spesifik. Lebih jelasnya ditunjukkan gambar hubungan tersebut sebagai berikut.

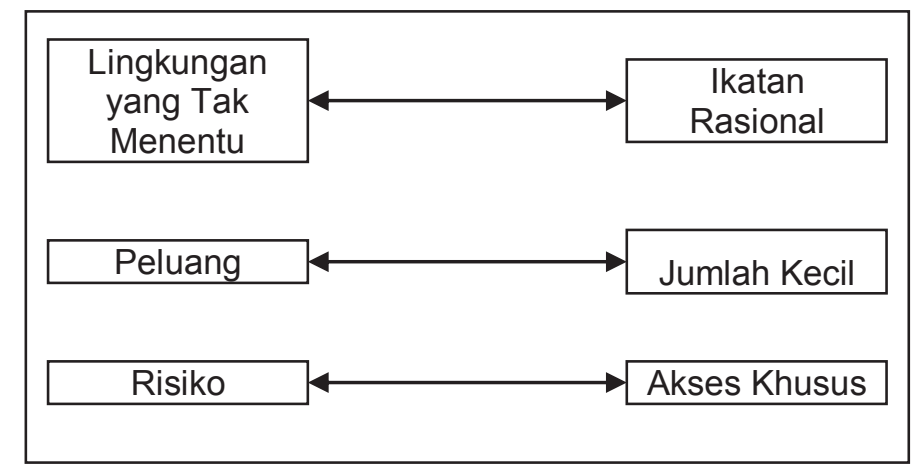

Gambar 2.13 Sumber-sumber biaya transaksi (Gareth R, Jones, 2004: 98) 
Gambar ini menunjukkan bahwa sumber biaya transaksi pelayanan yang diterapkan oleh organisasi sangat tergantung pada kondisi kebutuhan pembiayaan sumber daya dan kebutuhan lingkungan kerja. Hal yang sering dipertimbangkan dalam pemenuhan kebutuhan sumber daya dalam hal ini sumber daya manusia yaitu sering diperhadapkan oleh adanya biaya yang tidak menentu (environmental uncertainty), sehingga memiliki keterkaitan timbal balik dengan adanya pertimbangan ikatan rasional dalam penetapan pembiayaan. Termasuk pula dalam melakukan pembiayaan untuk mendapatkan peluang selalu mempertimbangkan adanya pemanfaatan atau penggunaan kerugian yang jumlahnya sekecil mungkin. Tentunya ini tidak terlepas dari pengambilan keputusan untuk menghindari suatu risiko yang timbul dari penggunaan aset-aset khusus dalam suatu organisasi.

Pandangan biaya transaksi merupakan sebuah mata rantai yang saling terkait dalam mencapai tujuan pelayanan organisasi. Stemma, Patrick (2007: 22) menyatakan biaya transaksi pelayanan selalu melibatkan hubungan mata rantai yang saling terkait satu sama lainnya. Unsur yang terlibat tersebut meliputi unsur lingkungan kerja, peluang kerja, risiko kerja, ikatan rasionalitas, jumlah aktivitas dan aset khusus. Lebih jelasnya ditunjukkan pada gambar di bawah ini:

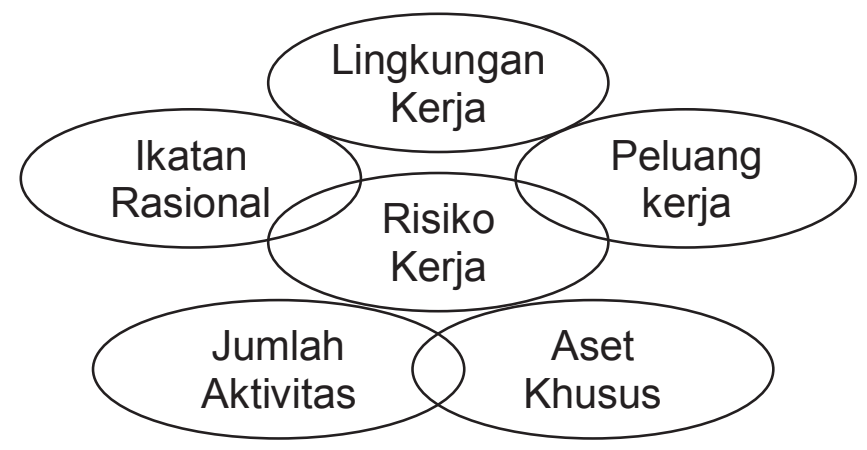

Gambar 2.14 Mata rantai biaya transaksi pelayanan dalam organisasi (Stemma, Patrick, 2007: 22)

Gambar ini menunjukkan bahwa mata rantai biaya transaksi dalam pelayanan organisasi merupakan suatu hubungan yang saling berkaitan dalam memperkuat suatu kegiatan pelayanan yang menjadi rantai yang saling berhubungan satu sama lain. 
Pandangan tentang pentingnya tentang biaya transaksi pelayanan dapat dilihat dari teori bingkai pembiayaan yang ditunjukkan oleh Murdock, James P. (2005: 69) bahwa suatu tujuan organisasi akan terwujud bila pembiayaan transaksi pelayanan jelas terlihat diterapkan. Kejelasan biaya transaksi pelayanan terlihat dalam bingkai pelayanan apabila didukung empat dasar sudut pandang sisi biaya transaksi pelayanan berupa biaya informasi, biaya teknologi, biaya administrasi dan biaya operasional. Lebih jelasnya digambarkan sebagai berikut.

Biaya Informasi Biaya Administrasi

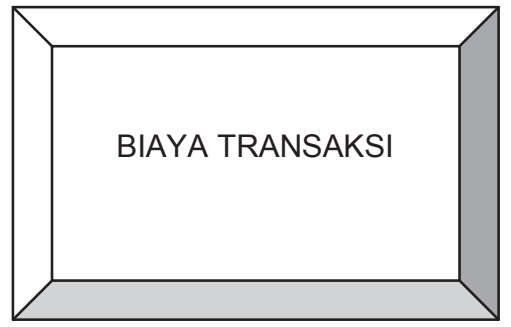

Biaya Operasional

Biaya Teknologi

Gambar 2.15 Bingkai biaya transaksi (Murdock, James P., 2005: 69)

Murdock, James P. (2005: 70) menjelaskan bahwa bingkai biaya transaksi pelayanan yang diterapkan dalam suatu organisasi selalu mempertimbangkan adanya komponen biaya informasi, biaya teknologi, biaya administrasi dan biaya operasional yang digunakan oleh organisasi untuk memberikan pelayanan yang baik dalam menjalankan berbagai aktivitas birokrasi yang membutuhkan pembiayaan. Atas dasar tersebut diperlukan strategi pembiayaan transaksi yang mampu memberikan suatu kondisi pelayanan yang kondusif pada lingkungan kerja.

Berdasarkan gambaran tersebut dapat diambil suatu kesimpulan bahwa keberhasilan suatu organisasi dalam memberikan pelayanan tidak terlepas dari penerapan biaya transaksi. Pada intinya peruntukan biaya transaksi dapat dilihat dari adanya biaya informasi, biaya teknologi, biaya administrasi dan biaya operasional. 


\section{BAGIAN IV \\ KONTEKS PENGADAAN BARANG \\ DAN JASA PEMERINTAH}

\section{A. Anggaran Pengadaan ATK dan Pemeliharaan Kendaraan Dinas \\ 1. Anggaran Pengadaan ATK}

Berdasarkan data yang diperoleh dari dokumen pelaksanaan anggaran SKPD pada Biro Keuangan dan Kekayaan Sekretariat Daerah Provinsi Maluku tahun 2011 diperoleh data besarnya anggaran untuk kegiatan pengadaan ATK pada Biro Keuangan dan Kekayaan Sekretariat Daerah Provinsi Maluku adalah Rp 154.281.000. Adapun distribusi penggunaan dana tersebut dibagi secara merata pada setiap triwulan yaitu masing-masing $\mathrm{Rp} 38.570 .250$. Jadi realisasi sampai akhir tahun 2011 sebesar Rp 154.281.000.

Dari uraian di atas menunjukkan bahwa semua anggaran tersebut habis digunakan untuk kegiatan pengadaan ATK. Adapun capaian kinerja berdasarkan indikator keluaran (output) dari penggunaan dana tersebut adalah terlaksananya pengadaan ATK pada Biro Keuangan dan Kekayaan Sekretariat Daerah Provinsi Maluku yang terdiri atas pengadaan kertas, buku tulis, map binder, karbon daito, kuitansi, amplop, tinta suntik, cartridge, tinta cap, bantal cap, isi hekter, tip X, lem, gunting, stabile, spidol, mistar, strok mesin hitung, pena, pensil dan lain-lain. Selanjutnya, hasil (outcome) dari kegiatan tersebut adalah kelancaran tugastugas perkantoran.

\section{a. Anggaran Pemeliharaan Kendaraan Dinas}

Berdasarkan data yang diperoleh dari dokumen pelaksanaan anggaran SKPD pada Biro Keuangan dan Kekayaan Sekretariat Daerah Provinsi Maluku tahun 2011diperoleh data anggaran untuk kegiatan pemeliharaan kendaraan dinas pada Biro Keuangan dan Kekayaan Sekretariat Daerah Provinsi Maluku adalah Rp 277.795.000. Adapun distribusi penggunaan dana tersebut dibagi secara merata pada setiap triwulan yaitu masing-masing Rp 69.448.750. Jadi realisasi sampai akhir tahun 2011 sebesar Rp 277.795.000.

Dari uraian di atas menunjukkan bahwa semua anggaran tersebut habis digunakan untuk kegiatan pemeliharaan kendaraan dinas. Adapun capaian kinerja berdasarkan indikator keluaran (output) dari penggunaan dana tersebut adalah terlaksananya pemeliharaan kendaraan dinas pada Biro 
Keuangan dan Kekayaan Sekretariat Daerah Provinsi Maluku yang terdiri atas 14 unit roda dua dan 8 unit roda empat. Selanjutnya, hasil (outcome) dari kegiatan tersebut adalah kelancaran tugas-tugas di luar kantor.

\section{Proses Pengadaan ATK dan Pemeliharaan Kendaraan Dinas}

\section{a. Proses Pengadaan Alat Tulis Kantor (ATK)}

Untuk menentukan proses pengadaan ATK pada Biro Keuangan dan Kekayaan Sekretariat Daerah Provinsi Maluku tahun 2011, penulis melakukan wawancara mendalam tentang sistem pengadaan ATK kepada beberapa informan yang terkait langsung dengan proses pengadaan ATK pada tahun 2011.

Hasil wawancara penulis kepada pejabat pembuat komitmen (PPK) tentang susunan panitia pengadaan barang:

Untuk pengadaan alat tulis kantor (ATK) pada tahun 2011 pada Biro Keuangan dan Kekayaan Sekretariat Daerah Provinsi Maluku terdapat panitia pengadaan barang yang terdiri atas 1 orang PA/KPA, 1 orang PPK, 3 orang pejabat pengadaan (1 kepala pengadaan, 1 orang sekretaris, 1 orang staf pendukung) dan 1 orang pejabat penerima hasil pekerjaan. Panitia ini yang bertugas melaksanakan pengadaan ATK.

Dari informasi di atas menunjukkan bahwa sudah ada panitia pengadaan barang yang dibentuk yang terdiri atas 6 orang. Setiap orang tentu mempunyai tugas masing-masing. Hal ini diperkuat dengan hasil wawancara penulis kepada pejabat pembuat komitmen (PPK) tentang tugas dari masingmasing panitia tersebut:

1. Tugas PA/KPA adalah menetapkan rencana umum pengadaan barang, mengumumkan rencana umum pengadaan barang, menetapkan PPK, menetapkan pejabat pengadaan, menetapkan penerima barang, menetapkan perusahaan/toko penyedia ATK. Mengawasi pelaksanaan pengadaan ATK dan mengawasi penyimpanan dokumen pengadaan ATK.

2. Tugas PPK adalah menetapkan rencana pelaksanaan pengadaan ATK, menerbitkan surat penunjukan penyedia barang ATK, membuat dan menandatangani kontrak pengadaan ATK dengan penyedia ATK, melaporkan pelaksanaan/penyelesaian pengadaan ATK, menyerahkan 
hasil pekerjaan pengadaan barang/jasa kepada KPA dan menyimpan dokumen pengadaan ATK.

3. Tugas pejabat pengadaan adalah menyusun rencana pemilihan penyedia ATK, mengumumkan pelaksanaan pengadaan barang ATK, menilai kualifikasi penyedia ATK, melakukan evaluasi administrasi, teknis dan harga terhadap penawaran yang masuk, membuat laporan mengenai proses dan hasil pengadaan ATK, menyampaikan laporan kegiatan pengadaan ATK kepada PPK,

4. Tugas pejabat penerima ATK adalah memeriksa dan menerima ATK, membuat dan menandatangani berita acara serah terima ATK.

Hasil wawancara penulis kepada pejabat pembuat komitmen (PPK) tentang cara menentukan penyedia ATK "Melalui penunjukan langsung".

Untuk menentukan penyedia ATK dilakukan dengan cara penunjukan langsung. Penunjukan langsung adalah metode pemilihan penyedia barang dengan cara menunjuk langsung 1 (satu) penyedia barang tanpa melalui lelang.

Salah satu contoh proses pelaksanaan pengadaan kertas, pejabat pengadaan barang melakukan pemeriksaan stok kertas lalu menaksir kebutuhan kertas dalam waktu sekitar 4 bulan. Selanjutnya mengorder kertas kepada penyedia barang ATK, kertas diantar oleh penyedia ATK lalu kertas tersebut diperiksa spesifikasi dan jumlahnya sesuai order, dibuat daftar serah terima barang, selanjutnya dibayar.

Berdasarkan uraian di atas, maka disusunlah proses pengadaan ATK pada Biro Keuangan dan Kekayaan Sekretariat Daerah Provinsi Maluku adalah sebagai berikut:

1. Pemilihan penyedia jasa pengadaan ATK dengan cara penunjukan langsung terdiri atas undangan kepada peserta terpilih dilampiri dokumen pengadaan; Pemasukan dokumen kualifikasi; Evaluasi kualifikasi; Pemberian penjelasan; Pemasukan dokumen penawaran; Evaluasi penawaran serta klarifikasi dan negosiasi teknis dan harga; Penetapan pemenang; Pengumuman pemenang; Penunjukan penyedia barang/jasa. 
2. Pelaksanaan pengadaan ATK terdiri atas pejabat pengadaan barang melakukan pemeriksaan stok barang, menaksir kebutuhan barang, koordinasi dengan penyedia barang ATK, datangkan barang, pemeriksaan barang, membuat daftar serah terima barang, pembayaran dan pengambilan bukti pembayaran.

3. Pelaporan pengadaan ATK terdiri atas penyusunan laporan, penggandaan laporan dan penyerahan laporan kegiatan pemeliharaan kendaraan dinas.

Memperhatikan metode pemilihan penyedia barang/jasa dalam Perpres No. 54 tahun 2010 diperoleh gambaran bahwa metode pemilihan penyedia barang/jasa dilakukan dengan metode pelelangan umum dan pelelangan sederhana, penunjukan langsung, pengadaan langsung, atau kontes/sayembara. Untuk itu, perlu dicari kemungkinan alternatif pengadaan ATK yang lebih baik selain penunjukan langsung. Sehubungan dengan itu, maka penulis melakukan pembanding dengan cara melakukan wawancara mendalam tentang proses pengadaan ATK kepada pejabat pengadaan barang/jasa di instansi yang lain yakni dalam hal ini dipilih Politeknik Negeri Ujung Pandang dengan pertimbangan mudah dalam mendapatkan informasi yang dibutuhkan.

Dari uraian di atas menunjukkan bahwa pengadaan ATK dapat dilakukan melalui pengadaan langsung. Pengadaan langsung adalah pengadaan barang/jasa langsung kepada penyedia barang/jasa, tanpa melalui pelelangan/seleksi/ penunjukan langsung.

b. Proses Pemeliharaan Kendaran Dinas pada Biro Keuangan dan Kekayaan Sekretariat Daerah Provinsi Maluku

Untuk menentukan proses pemeliharaan kendaraan dinas pada Biro Keuangan dan Kekayaan Sekretariat Daerah Provinsi Maluku tahun 2011, penulis melakukan wawancara mendalam tentang sistem pemeliharaan kendaraan dinas kepada beberapa informan yang terkait langsung dengan proses pemeliharaan kendaraan dinas pada tahun 2011.

Hasil wawancara penulis kepada pejabat pembuat komitmen (PPK) tentang susunan panitia pengadaan barang/jasa:

Untuk pemeliharaan kendaraan dinas pada tahun 2011 pada Biro Keuangan dan Kekayaan Sekretariat Daerah Provinsi Maluku terdapat panitia 
pengadaan barang/jasa yang terdiri atas 1 orang PA/KPA, 1 orang PPK, 3 orang pejabat pengadaan (1 kepala pengadaan, 1 orang sekretaris, 1 orang staf teknis) dan 1 orang pejabat penerima hasil pekerjaan. Panitia ini yang bertugas melaksanakan pemeliharaan kendaraan dinas.

Dari informasi di atas menunjukkan bahwa sudah ada panitia pengadaan barang/jasa yang dibentuk yang terdiri atas 7 orang. Setiap orang berada pada posisi yang berbeda. Hal ini diperkuat dengan adanya SK panitia pengadaan barang/jasa pada Biro Keuangan dan Kekayaan Sekretariat Daerah Provinsi Maluku.

Hasil wawancara penulis kepada pejabat pembuat komitmen (PPK) tentang cara menentukan penyedia barang/jasa pemeliharaan kendaraan dinas Cara menentukan penyedia barang/jasa yang berkaitan dengan pemeliharaan kendaraan dinas adalah melalui pelelangan umum yaitu metode pemilihan penyedia barang/jasa yang dapat diikuti oleh semua penyedia barang/jasa yang memenuhi syarat".

Selanjutnya, hasil wawancara penulis kepada pejabat pembuat komitmen (PPK) tentang tahapan dalam pemilihan penyedia jasa pemeliharaan kendaraan dinas pada Biro Keuangan dan Kekayaan Sekretariat Daerah Provinsi Maluku melalui pelelangan umum "Mengikuti tahapan pelelangan umum sesuai dalam Perpres No. 54 tahun 2010. Adapun tahapan dalam Perpres tersebut adalah PPK mengumumkan prakualifikasi. penyedia barang/jasa mendaftar dan mengambil dokumen kualifikasi. Penyedia barang/jasa memasukkan dokumen kualifikasi dan selanjutnya dievaluasi oleh pejabat pengadaan barang/jasa. Pembuktian kualifikasi dan pembuatan berita acara pembuktian kualifikasi. Menetapkan hasil kualifikasi, mengumumkan hasil kualifikasi. Memberi kesempatan kepada para penyedia barang/Jasa untuk memberikan sanggahan. Membuat undangan. kepada penyedia barang/jasa. Penyedia barang/jasa mengambil dokumen pemilihan. Pemberian penjelasan kepada penyedia barang/jasa. Penyedia barang/jasa memasukkan dokumen penawaran. Pejabat pengadaan barang/jasa membuka dokumen penawaran dalam sampul I untuk dievaluasi. Pejabat pengadaan barang mengumumkan peserta lelang yang lulus evaluasi sampul I. Selanjutnya pembukaan dokumen penawaran sampul II. Evaluasi dokumen penawaran sampul ii, pembuatan berita acara hasil pelelangan. Menetapkan pemenang lalu mengumumkan hasil pemenang. Diberi kesempatan kepada 
penyedia barang/jasa yang tidak menang untuk memberikan sanggahan jika diperlukan".

Hasil wawancara penulis kepada pejabat pengadaan barang/jasa tentang pelaporan kegiatan pemeliharaan kendaraan dinas:

"Setiap triwulan pejabat pengadaan barang/jasa membuat laporan kemajuan pemeliharaan kendaraan dinas dan biayanya. Sebelum akhir tahun dibuat laporan akhir pemeliharaan kendaraan dinas. Di sini dibuat beberapa rangkap. Ada disimpan oleh pejabat pengadaan barang/jasa dan ada pula diberikan kepada PPK dan Bagian keuangan. Dalam penyusunan pelaporan sering dilakukan koordinasi dengan PPK dan bagian keuangan"

Salah satu contoh proses pelaksanaan pemeliharaan kendaraan dinas yaitu service (perbaikan) kendaraan roda empat yaitu pejabat pengadaan barang/jasa memeriksa kerusakan kendaraan dan menaksir biaya perbaikan. Selanjutnya dibawa ke penyedia jasa perbaikan (bengkel) yang telah ditetapkan lalu diperiksa kerusakannya, penyedia jasa menetapkan biayanya. Selanjutnya dilakukan perbaikan kendaraan. Setelah selesai, pejabat pengadaan barang/jasa atau yang ditunjuk memeriksa hasil perbaikan. Setelah dinyatakan baik dilakukan pembayaran sehingga kendaraan tersebut bisa diambil (terkadang juga pembayarannya belakangan).

Berdasarkan uraian di atas, maka proses pemeliharaan kendaraan dinas pada Biro Keuangan dan Kekayaan Sekretariat Daerah Provinsi Maluku adalah sebagai berikut:

1. Proses pemilihan penyedia jasa pemeliharaan kendaraan dinas yang terdiri atas pengumuman prakualifikasi; pendaftaran dan pengambilan dokumen kualifikasi; pemasukan dan evaluasi dokumen kualifikasi; pembuktian kualifikasi; penetapan hasil kualifikasi; pengumuman hasil kualifikasi; sanggahan kualifikasi; undangan; pengambilan dokumen pemilihan; pemberian penjelasan; pemasukan dokumen penawaran tahap I; Pembukaan dokumen penawaran tahap I; evaluasi dokumen penawaran tahap I; penetapan peserta yang lulus evaluasi tahap I; pemberitahuan/ pengumuman peserta yang lulus evaluasi tahap I; pemasukan dokumen penawaran tahap II; pembukaan dokumen penawaran tahap II; evaluasi dokumen penawaran tahap II; pembuatan berita acara hasil pelelangan; penetapan pemenang; pengumuman 
pemenang; sanggahan; sanggahan banding (apabila diperlukan); penunjukan penyedia barang/jasa.

2. Proses pelaksanaan pemeliharaan kendaraan dinas yang terdiri atas pejabat pengadaan barang/jasa memeriksa kerusakan kendaraan dan menaksir biaya perbaikan; koordinasi dengan penyedia jasa perbaikan, pemeriksaan kendaraan; penentuan biaya dan kesepakatan harga; perbaikan/pemeliharaan kendaraan; melaksanakan perbaikan; evaluasi hasil perbaikan; pembayaran dan pengambilan bukti pembayaran lalu diserahkan ke pejabat pengadaan barang.

3. Proses pelaporan pengadaan pemeliharaan kendaraan dinas terdiri atas penyusunan laporan, penggandaan laporan dan penyerahan laporan kegiatan pemeliharaan kendaraan dinas.

Memperhatikan metode pemilihan penyedia barang/jasa dalam Perpres No. 54 tahun 2010 diperoleh gambaran bahwa metode pemilihan penyedia barang/jasa dilakukan dengan pelelangan yang terdiri atas pelelangan umum dan pelelangan sederhana, penunjukan langsung, pengadaan langsung, atau kontes/sayembara. Untuk itu, perlu dicari kemungkinan alternatif proses pemeliharaan kendaraan dinas yang lebih baik. Sehubungan dengan itu, maka penulis melakukan pembanding dengan cara melakukan wawancara mendalam tentang proses pemeliharaan kendaraan dinas kepada pejabat pengadaan barang/jasa di instansi yang lain yakni dalam hal ini dipilih Politeknik Negeri Ujung Pandang. Penulis menanyakan tentang metode pemilihan penyedia jasa pemeliharaan kendaraan dinas di Politeknik Negeri Ujung Pandang:

"Melalui pengadaan langsung. Adapun alasannya adalah perbaikan kendaraan dinas tidak bisa diadakan sekaligus. Kerusakan kendaraan susah diprediksi sehingga sulit melalui dilelang. Kerusakannya kadang situasional. Jadi sebaiknya menggunakan metode pengadaan langsung.

Selanjutnya, penulis menanyakan tentang proses pelaksanaan pemeliharaan kendaraan dinas:

"Biasanya pada saat ada kerusakan atau kondisi kendaraan perlu diservice maka langsung dibawa ke bengkel yang sudah ditetapkan. Jika kerusakan tiba-tiba dan kerusakan ringan biasa penanggung jawab pengguna kendaraan langsung service di tempat service yang dekat. 
Notanya nanti tinggal disetor di sub bagian perbaikan dan perawatan (maintenance and repaire)."

Selanjutnya, penulis menanyakan tentang laporan pertanggungjawaban:

"Setiap ada perbaikan dibuat administrasinya termasuk biayanya. Selanjutnya direkap dan dibuat laporannya. Jadi jelas semua berapa biayanya dan untuk apa."

Dari uraian di atas menunjukkan bahwa metode pemilihan penyedia jasa pemeliharaan kendaraan dinas dapat dilakukan melalui pengadaan langsung.

\section{Proses Pengadaan ATK dan Pemeliharaan Kendaraan Dinas pada Biro Keuangan} dan Kekayaan Sekretariat Daerah Provinsi Maluku Dinilai dari Perspektif Teori

Untuk memahami proses pengadaan ATK dan pemeliharaan kendaraan dinas Proses pengadaan ATK dan pemeliharaan kendaraan dinas dinilai dari Transaction Cost mengacu pada teori yaitu teori informasi asimetrik (asymmetric information), teori perilaku peluang (opportunity behavior) dan teori efisiensi nilai ekonomis (efficiency economic value). Dalam menilai efisiensi nilai ekonomi, tentu tidak terlepas dari besarnya biaya transaksi. Besarnya biaya transaksi adalah merupakan akumulasi dari komponen biaya transaksi yang terdiri atas biaya informasi, biaya teknologi, biaya administrasi dan biaya operasional. Dalam menganalisis nilai ekonomi terkait pula dengan efisiensi dan efektivitas dari biaya transaksi.

\section{a. Perspektif Teori Informasi Asimetri (Asymmetric Information) dalam Menganalisis Biaya Transaksi}

Asymmetric information adalah perbedaan informasi yang dimiliki oleh service supply (aparat pelayanan) dengan informasi yang diketahui dan diterima oleh service demand (masyarakat yang dilayani) (Tietz, 2002: 121). Aparat pelayanan dalam hal ini adalah semua pegawai yang memberikan pelayanan kepada masyarakat yakni penyedia barang/jasa. Untuk menganalisis informasi asimetri ini, penulis melakukan wawancara mendalam terhadap salah satu penyedia jasa pemeliharaan kendaraan dinas tentang ada tidaknya asimetri informasi antara aparat pelayanan dengan penyedia jasa: 
"Dalam pemilihan penyedia jasa, terkadang ada informasi yang kita butuhkan tapi tidak diberitahu oleh aparat. Terkadang aparat tidak terbuka dengan alasan itu rahasia atau bukan kewenangan saya untuk menjawabnya. Terkadang aparat tidak terbuka dan tidak adil dalam memberikan informasi. Untuk itu, kita harus pandai-pandai mengambil hati aparat supaya bisa memberikan informasi terutama dalam proses lelang pekerjaan."

Selanjutnya penulis menanyakan, apakah menurut Anda Semakin tinggi asymmetric information (perbedaan informasi yang dimiliki oleh aparat pelayanan dengan informasi yang diketahui dan diterima oleh masyarakat) maka semakin rendah kualitas pelayanan organisasi kepada publik: "ya, jelas. Makin tidak jelas informasi, makin simpangsiurnya informasi tentu pelayanan menjadi lama dan sudah"

Selain itu, penulis meminta kepada penyedia barang ATK memberikan contoh tentang asymmetric information berupa perbedaan informasi yang diterima dengan yang disampaikan oleh aparat pelayanan. Penyedia ATK tersebut menceritakan bahwa:

"Pernah setelah saya menyerahkan barang ATK kepada panitia pengadaan barang, langsung saya meminta bayarannya. Panitia pengadaan barang tersebut sampaikan datanglah 3 hari kemudian. Berdasarkan informasi tersebut, maka 3 hari kemudian saya datang tapi ternyata dananya belum ada dan diberi tahu lagi bisa datang 3 hari kemudian sehingga setelah 3 hari saya datang lagi, ternyata belum bisa juga dibayarkan dengan alasan belum ada dana turun dari keuangan. Selanjutnya saya cek di keuangan ternyata dari keuangan menyatakan harus ada dulu laporan dari panitia pengadaan barang. Selanjutnya, saya sampaikan kepada panitia pengadaan barang lalu disampaikan silahkan ditunggu saja. Setelah saya 2 jam menunggu, juga belum selesai sehingga saya tanyakan lagi. Lalu panitia pengadaan barang menyatakan bahwa maksudnya ditunggu saja adalah ditunggu sampai selesai proses administrasinya baru bisa dibayarkan, jadi bukan berarti ditunggu sekarang uangnya. 1 minggu kemudian saya diminta datang terima uangnya. Waktu saya datang mau terima uangnya lalu diminta pulang dulu ambil stempel perusahaan sehingga saya pulang ambil stempel perusahaan 
kemudian kembali lagi ke kantor untuk menerima uangnya tapi ternyata yang pegang uangnya lagi keluar kantor sehingga besoknya saya datang lagi baru bisa diterima dananya. Ini informasinya tidak jelas sehingga tidak efisien."

Sebaliknya, penulis juga meminta kepada panitia pengadaan barang dan jasa memberikan contoh tentang asymmetric information yang pernah dialami dalam kegiatan pemeliharaan kendaraan dinas. Panitia pengadaan barang dan jasa tersebut menceritakan bahwa:

"Pernah ada mobil dinas tergores pada beberapa bagian permukaan
sehingga saya diminta bawa ke bengkel untuk didico (dicat). Informasi
dari bengkel bahwa selesai 6 hari kemudian. Setelah 6 hari saya
datang mau mengambil tersebut, ternyata belum selesai yakni masih
dalam proses dico. Alasannya bahwa masih ada yang duluan sehingga
terlambat mulai dikerjakan. Selanjutnya, saya dijanji bahwa selesai 3
hari mendatang, sehingga saya datang setelah 3 hari. Mobil tersebut
diambil dan diserahkan ke penanggungjawab pengguna mobil
tersebut. Lalu penanggungjawab pengguna mobil tersebut
menanyakan apakah sudah diganti kanvas koplengnya, Saya jawab
tidak. Penanggung jawab pengguna mobil marah, pada hal tidak ada
penyampaian sebelumnya bahwa sekaligus ganti juga kanvas
koplengnya. Pada hari itu juga saya diminta lagi bawa ke bengkel
tersebut untuk ganti kanvas kopleng dan 2 hari kemudian baru
diambil.

Dari uraian di atas menunjukkan adanya asymmetric information yang dapat mempengaruhi besarnya biaya transaksi.

\section{b. Perspektif Teori Opportunity Behavior dalam Menganalisis Biaya Transaksi}

Opportunity behavior adalah perilaku aparat pelayanan dalam mencari dan memanfaatkan peluang untuk memberikan pelayanan yang terbaik dan meminimasi biaya transaksi (Webley (2005: 155), Traub, (2000: 122), Tversky (2004: 74) dan Tietz (2002: 163))

Untuk menganalisis biaya transaksi dengan menggunakan perspektif teori Opportunity behavior, penulis melakukan wawancara mendalam terhadap salah satu penyedia jasa pemeliharaan kendaraan dinas tentang 
ada perilaku aparat untuk memberikan pelayanan optimal dengan menekan biaya seminimal mungkin:

“Pelayanan yang optimal kepada masyarakat biasa diusahakan dan dilaksanakan oleh aparat pemerintah, tapi meminimalkan biaya transaksi hanya retorika saja. Prosesnya bisa dibuat sederhana tapi transaksi tetap tinggi bahkan terkadang ada yang sengaja persulit ada alasan untuk mengenakan biaya atau bisa juga supaya ada fee. Sebagai pengusaha, jika ada untung yang kita peroleh kita ihlas mengeluarkan dan demi kelancaran pekerjaan dan kelanjutan kerja sama."

Selanjutnya penulis melakukan wawancara terhadap salah satu aparat pelayanan tentang ada perilaku aparat untuk memberikan pelayanan optimal dengan menekan biaya seminimal mungkin:

"Kita selalu berusaha memberikan pelayanan terbaik, tapi kita juga mengharapkan honor atau insentif yang tinggi. Jika bisa honornya tinggi untuk apa dikurangi."

Selanjutnya penulis menanyakan, apakah menurut Anda semakin tinggi opportunity behavior (perilaku aparat pelayanan dalam mencari dan memanfaatkan peluang untuk memberikan pelayanan yang terbaik dan meminimasi biaya transaksi) maka semakin tinggi kualitas pelayanan organisasi kepada publik: "ya, benar"

Selain itu, penulis meminta kepada penyedia barang ATK memberikan contoh tentang Opportunity behavior yaitu perilaku aparat pelayanan dalam mencari dan memanfaatkan peluang untuk memberikan pelayanan yang terbaik. Penyedia barang ATK tersebut menceritakan bahwa:

"Sebagai contoh pada saat saya meminta uang pembayaran atas ATK yang saya sudah serahkan, itu berbelit-belit dan tidak punya inisiatif untuk menghubungi kita pada saat lewat waktu janjinya sementara belum bisa dia penuhi. Kan sebaiknya diinformasikan kepada kita jika ingin memberikan pelayanan yang baik".

Dari hasil wawancara di atas menunjukkan bahwa ditinjau dari teori Opportunity behavior aparat (birokrasi) adalah masih adanya aparat yang tidak menggunakan kesempatan dengan baik untuk memberikan pelayanan optimal kepada masyarakat. 
c. Perspektif Teori efficiency economic value dalam Menganalisis Biaya Transaksi

Efficiency economic value adalah aktivitas yang dilakukan oleh aparat pelayanan dalam memberikan pelayanan dengan mempertimbangkan nilai secara ekonomis dari hasil pelayanan tersebut (Viscusi, WK. (2003: 79), Wittman, DA (2004: 246) dan Birl, Higgins (2003: 195)).

Untuk menganalisis biaya transaksi dengan menggunakan perspektif teori efficiency economic value, penulis melakukan wawancara mendalam terhadap salah satu penyedia jasa pemeliharaan kendaraan dinas tentang efisiensi nilai ekonomi yang dilakukan oleh aparat pelayanan:

Untuk menganalisis biaya transaksi dengan menggunakan perspektif teori efficiency economic value, penulis melakukan wawancara mendalam terhadap penyedia barang ATK dan penyedia jasa pemeliharaan kendaraan dinas tentang aktivitas efisiensi yang dilakukan oleh aparat pelayanan. Menurut penyedia barang ATK adalah:

"Aparat pelayanan memang terkadang melakukan efisiensi dalam hal proses tapi dalam hal besarnya biaya transaksi saya kira tidak, Terkadang aparat membantu memperlancar karena ada harapan penyedia barang bisa ada pengertian untuk bisa memberikan sebagian keuntungan tapi tidak semua begitu karena ada juga yang memang betul-betul membantu kelancaran proses.

Selanjutnya penulis melakukan wawancara terhadap pejabat pengadaan barang/jasa tentang aktivitas yang dilakukan oleh aparat pelayanan dalam rangka melakukan efisiensi biaya transaksi dengan tetap mengusahakan agar hasilnya tetap menguntungkan secara ekonomi:

"Ya, kita berusaha memberikan pelayanan sebaik mungkin, namun tidak dipungkiri bahwa terkadang kita mengharapkan adanya pengertian dari orang yang dilayani."

Selanjutnya penulis menanyakan, apakah menurut Anda semakin tinggi efficiency economic value, maka semakin tinggi kualitas pelayanan organisasi kepada publik: "ya, benar" 
Selanjutnya penulis menanyakan, apakah menurut Anda semakin tinggi efficiency economic value, maka semakin tinggi kualitas pelayanan organisasi kepada publik: "ya, benar"

Dari hasil wawancara di atas menunjukkan bahwa ada kecenderungan biaya yang tinggi akan menyebabkan pelayanan berkualitas, atau pelayanan yang berkualitas diharapkan dibarengi dengan adanya insentif.

Selanjutnya, penulis melakukan wawancara kepada pejabat pengadaan barang/jasa pada tahun 2011 tentang efektivitas proses transaksi pengadaan ATK dan pemeliharaan kendaraan dinas dan efektivitas penggunaan anggaran:

"Dalam proses pengadaan ATK dimana langsung disorder banyak barang, maka terkadang memang ada barang yang cepat habis sementara ada barang lain tersisa. Kendaraan dinas terkadang memang terlambat dilakukan perbaikan sehingga terkadang dapat mengganggu kelancaran pelaksanaan tugas, tapi hal itu dapat diatasi dengan menggunakan kendaraan lain. Dalam proses tersebut ada biaya yang kita keluarkan untuk seperti honorarium panitia diberikan kepada panitia yang memang bekerja, biaya transportasi diberikan kepada panitia yang menggunakan transportasi mengurus pemeliharaan kendaraan dinas seperti pergi ke bengkel, konsumsi diberikan pada waktu rapat atau bekerja. Jadi biaya transaksi yang dikeluarkan betul-betul digunakan untuk mengurus pemeliharaan kendaraan dinas.."

Dari hasil wawancara tersebut menunjukkan bahwa terkadang proses pengadaan ATK dan pemeliharaan kendaraan dinas tidak sesuai dengan harapan. Walaupun semua anggaran dipakai beli barang/jasa akan tetapi efektivitasnya belum optimal.

Selanjutnya, penulis melalukan wawancara kepada pejabat pembuat komitmen dan pejabat pengadaan barang tentang perkiraan rincian biaya transaksi pengadaan ATK pada tahun 2011 yang terdiri atas biaya informasi, biaya teknologi, biaya administrasi dan biaya operasional. Selanjutnya, penulis menghitung besarnya biaya transaksi tersebut. Adapun hasilnya sebagaimana pada uraian berikut ini: 
1. Biaya Informasi

Rincian besarnya biaya informasi terdiri atas biaya pulsa telpon, HP dan internet sebagaimana pada tabel berikut.

\begin{tabular}{|c|l|r|r|}
\hline No & \multicolumn{1}{|c|}{ Komponen biaya } & \multicolumn{1}{c|}{ Volume } & \multicolumn{1}{|c|}{ Biaya transaksi (Rp) } \\
\hline 1 & Biaya telepon & $6 \times \mathrm{Rp} 2.000$ & 12.000 \\
\hline 2 & Pulsa HP & $25 \times \mathrm{Rp} \mathrm{5.000}$ & 125.000 \\
\hline 3 & Jasa internet & $5 \times \mathrm{Rp} 8.000$ & 40.000 \\
\hline \multicolumn{2}{|c|}{ Jumlah } & & 165.000 \\
\hline
\end{tabular}

Tabel 4.1 Biaya informasi pengadaan ATK

Sumber: Hasil wawancara kepada pejabat pembuat komitmen dan pejabat pengadaan barang

2. Biaya Teknologi

Rincian besarnya biaya teknologi terdiri atas biaya HP/pesawat telepon, perangkat internet, komputer/laptop dan printer sebagaimana pada tabel berikut.

Tabel 4.2 Biaya teknologi pengadaan ATK

\begin{tabular}{|c|c|c|c|}
\hline No & Komponen biaya & Volume & Biaya transaksi (Rp) \\
\hline 1 & Pesawat telepon & $0,5 \%$ x Rp 200.000 & 1.000 \\
\hline 2 & Pesawat HP & $0,5 \% \times \operatorname{Rp} 2.000 .000$ & 10.000 \\
\hline 3 & Perangkat internet & $0,05 \%$ x Rp 4.000 .000 & 2.000 \\
\hline 4 & Komputer/Laptop & $0,5 \%$ x Rp 3.000 .000 & 15.000 \\
\hline 5 & Printer & $1 \% \times \operatorname{Rp} 1.000 .000$ & 10.000 \\
\hline \multicolumn{3}{|c|}{ Jumlah } & 38.000 \\
\hline
\end{tabular}

Sumber: Hasil wawancara kepada pejabat pembuat komitmen dan pejabat pengadaan barang 


\section{Biaya Administrasi}

Rincian besarnya biaya administrasi terdiri atas biaya kertas, buku, map, alat tulis, tinta printer, amplop, bantal cap, hekter, isi hekter, materai, dan foto copy.

4. Biaya Operasional

Rincian besarnya biaya operasional terdiri atas biaya honorarium, konsumsi, transportasi dan listrik sebagaimana pada tabel berikut.

Tabel 4.4 Biaya operasional pengadaan ATK

\begin{tabular}{|c|l|r|c|}
\hline No & \multicolumn{1}{|c|}{ Komponen biaya } & \multicolumn{1}{|c|}{ Volume } & Biaya transaksi (Rp) \\
\hline 1 & Honor KPA & 1 orang & 960.000 \\
\hline 2 & Honor PPK & 1 orang & 900.000 \\
\hline 3 & Honor Kepala & 1 orang & 900.000 \\
\hline 4 & Honor Sekretaris & 1 orang & 720.000 \\
\hline 5 & Honor Staf pendukung & 1 orang & 600.000 \\
\hline 6 & Konsumsi makanan besar & 20 orang x Rp 20.000 & 200.000 \\
\hline 7 & Konsumsi makanan kecil & 10 orang x Rp 8000 & 160.000 \\
\hline 8 & Transportasi & 5 kali x Rp 40.000 & 200.000 \\
\hline 9 & Listrik & 1 paket & 340.000 \\
\hline \multicolumn{2}{|c|}{ Jumlah } & 4.980 .000 \\
\hline
\end{tabular}

Sumber: Hasil wawancara kepada pejabat pembuat komitmen dan pejabat pengadaan barang

Berdasarkan hasil perhitungan jumlah dari setiap komponen biaya transaksi, maka disusunlah rekapitulasi biaya transaksi pengadaan ATK pada Biro Keuangan dan Kekayaan Sekretariat Daerah Provinsi Maluku tahun 2011 sebagaimana pada tabel berikut ini.

Tabel 4.5 Rekapitulasi biaya transaksi pengadaan ATK

\begin{tabular}{|r|l|r|}
\hline No & Komponen biaya & \multicolumn{2}{|c|}{ Biaya transaksi (Rp) } \\
\hline 1 & Biaya informasi & 165.000 \\
\hline 2 & Biaya teknologi & 38.000 \\
\hline 3 & Biaya administrasi & 384.000 \\
\hline 4 & Biaya operasional & 4.980 .000 \\
\hline & Total & 5.567 .000 \\
\hline
\end{tabular}


Berdasarkan rekapitulasi jumlah biaya transaksi berdasarkan komponen biaya transaksi di atas, maka dihitunglah rasio komponen biaya transaksi terhadap total biaya transaksi dengan menggunakan rumus:

$$
\mathrm{RBTi}=\frac{\mathrm{BTi}}{\mathrm{TBT}}
$$

Dimana:

$\mathrm{RBTi}=$ Rasio biaya transaksi komponen ke-i terhadap total biaya transaksi

$\mathrm{BTi}=$ jumlah biaya transaksi komponen ke- $\mathrm{i}$

TBT = Total biaya transaksi

Tabel 4.6 Rasio komponen biaya transaksi terhadap total biaya transaksi

\begin{tabular}{|r|l|r|r|c|r|}
\hline No & Komponen biaya & Biaya transaksi (Rp) & \multicolumn{3}{|c|}{ Rasio } \\
\hline 1 & Biaya informasi & 165.000 & 0,03 & Atau & 2,96 \\
\hline 2 & Biaya teknologi & 38.000 & 0,01 & Atau & 0,68 \\
\hline 3 & Biaya administrasi & 384.000 & 0,07 & Atau & 6,90 \\
\hline 4 & Biaya operasional & 4.980 .000 & 0,89 & Atau & 89,46 \\
\hline \multicolumn{2}{|c|}{ Total } & 5.567 .000 & 1,00 & Atau & 100,00 \\
\hline
\end{tabular}

Untuk lebih jelasnya dapat dilihat pada gambar berikut ini.

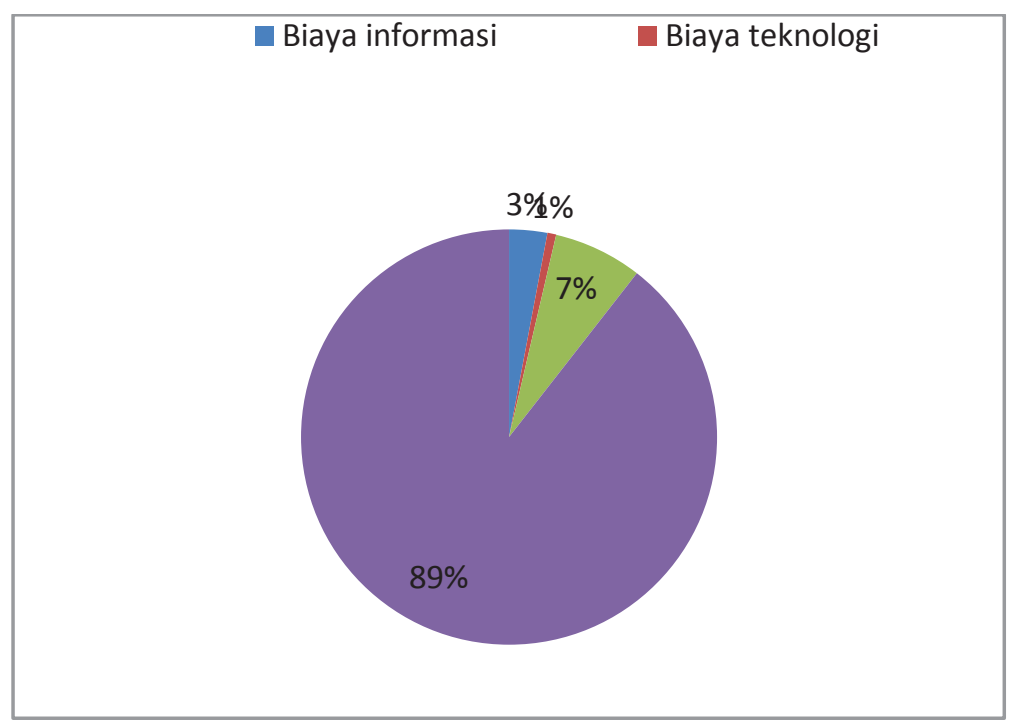

Gambar 4.1 Rasio komponen biaya transaksi terhadap total biaya transaksi pengadaan ATK (Sumber: Hasil perhitungan rasio pada tabel 4.6) 
Dari tabel dan gambar di atas menunjukkan bahwa biaya dan rasio terbesar dari ke empat komponen biaya transaksi tersebut adalah biaya operasional sedang yang terkecil adalah biaya teknologi.

Adapun tinjauan dari perspektif teori efficiency economic value dalam proses pengadaan ATK sebagaimana yang diuraikan dalam proses pencairan dana (pembayaran) barang ATK yang menunjukkan adanya asymetric information sehingga hal itu menyebabkan biaya transaksi yang dikeluarkan menjadi lebih besar dari yang seharusnya. Selain itu, berdasarkan hasil penelusuran penulis terhadap harga barang di pasaran melalui wawancara terhadap penjual kertas di pasar (toko) diperoleh informasi bahwa harga kertas A4 tahun 2011 adalah Rp 34.000 per rim, Hasil wawancara terhadap salah satu pemilik perusahaan supplier menawarkan harga kertas A4 adalah Rp 39.000 per rim sementara harga pengadaan kertas A4 di Sekretariat Daerah Provinsi Maluku adalah Rp 45.000 per rim. Ini menunjukkan bahwa biaya pengadaan ATK khususnya kertas A4 di Sekretariat Daerah Provinsi Maluku adalah lebih tinggi dari harga pasar. Jadi perspektif teori efficiency economic value terhadap biaya transaksi pengadaan ATK pada Biro Keuangan dan Kekayaan Sekretariat Daerah Provinsi Maluku tahun 2011 adalah kurang efisien. Jika dilakukan efisiensi harga kertas A4 dengan mengadakan kertas A4 pada supplier yang lebih murah harganya, maka terjadi penurunan harga dari $\mathrm{Rp} 45.000$ menjadi $\mathrm{Rp}$ 39.000. Adapun prosentase harga kertas yang dapat diturunkan adalah sebesar = $\frac{45000-39000}{45000} \times 100 \%=13,3 \%$. Ini mengindikasikan bahwa dapat dilakukan efisiensi harga kertas A4 sebesar $13,3 \%$.

\section{1) Besarnya Biaya Transaksi Dalam Proses Pemeliharaan kendaraan Dinas}

Dalam kegiatan pemeliharaan kendaraan dinas ada proses yang dilalui sebagaimana halnya dalam proses pengadaan ATK. Dalam proses tersebut tentu membutuhkan biaya. Biaya tersebut dibagi atas empat macam yaitu biaya informasi, biaya teknologi, biaya administrasi dan biaya operasional.

Biaya informasi di sini adalah biaya yang dikeluarkan oleh pemerintah untuk membiayai kebutuhan informasi dalam transaksi pemeliharaan kendaraan dinas pada Biro Keuangan dan Kekayaan Sekretariat Daerah Provinsi Maluku tahun 2011. Biaya Informasi ini terdiri atas biaya pulsa 
telepon/HP dan pulsa internet dalam mencari dan menyampaian informasi dari atau kepada orang lain.

Biaya teknologi di sini adalah biaya yang dikeluarkan oleh pemerintah untuk membiayai sarana teknologi dalam transaksi pemeliharaan kendaraan dinas pada Biro Keuangan dan Kekayaan Sekretariat Daerah Provinsi Maluku tahun 2011. Biaya teknologi terdiri atas biaya biaya pesawat telepon/HP, Perangkat internet, Komputer dan printer. Biaya pesawat telepon/HP digunakan dalam membiayai pengadaan pesawat telepon/HP dalam rangka melakukan komunikasi. Biaya perangkat internet digunakan dalam membiayai perangkat internet yang digunakan dalam mencari dan menyampaikan informasi, memberikan pengumuman dan komunikasi lewat internet. Biaya komputer digunakan dalam membiayai pengadaan komputer yang digunakan untuk melakukan pengetikan surat/dokumen dan pencarian informasi serta komunikasi melalui internet. Biaya printer digunakan dalam pembiayai pengadaan printer yang digunakan dalam rangka mencetak surat dan dokumen yang terkait pemeliharaan kendaraan dinas.

Biaya administrasi di sini adalah biaya yang dikeluarkan oleh pemerintah untuk membiayai kebutuhan administrasi dalam transaksi pemeliharaan kendaraan dinas pada Biro Keuangan dan Kekayaan Sekretariat Daerah Provinsi Maluku tahun 2011. Biaya administrasi tersebut terdiri atas biaya kertas, buku, map, materai, pulpen, tinta printer, bantal cap, amplop, hekter, isi hekter dan foto copy. Biaya buku dan kertas digunakan dalam membiayai pembelian buku dan kertas sebagai tempat melakukan pencatatan administrasi. Biaya alat tulis digunakan membiayai pembelian alat tulis yang digunakan dalam menulis pencatatan dan surat dalam administrasi. Biaya materai digunakan dalam membiayai pembelian materai untuk memperkuat legitimasi surat dan kuitansi. Biaya foto copy dan penjilidan digunakan dalam membiayai penggandaan surat-surat dan laporan.

Biaya operasional di sini adalah biaya yang dikeluarkan oleh pemerintah untuk membiayai kebutuhan operasional dalam pemeliharaan kendaraan dinas pada Biro Keuangan dan Kekayaan Sekretariat Daerah Provinsi Maluku tahun 2011. Biaya operasional ini terdiri atas biaya honorarium, konsumsi, transportasi dan listrik. Biaya honorarium digunakan dalam membiayai honor tim yang terkait dengan pemeliharaan kendaraan 
dinas yang melakukan perencanaan, penunjukan penyedia jasa, penerimaan jasa, pemeriksaan jasa, pengarsipan dan pelaporan. Tim ini terdiri atas KPA, PPK, kepala, sekretaris dan staf pendukung. Biaya konsumsi digunakan dalam membiayai pembelian konsumsi dalam bentuk makanan berat dan makanan ringan untuk tim pada saat melaksanakan kegiatan operasional seperti rapat. Biaya transportasi digunakan dalam membiayai transportasi tim dalam melakukan survei calon penyedia barang/jasa, survei barang/jasa dan harga barang/jasa. Biaya listrik digunakan dalam membiayai energi listrik yang digunakan dalam kegiatan operasional seperti listrik untuk perangkat komputer dan penerangan listrik.

Untuk menentukan besarnya biaya transaksi tersebut, maka perlu ditelusuri biaya yang terkait dengan sistem pemeliharaan kendaraan dinas pada Biro Keuangan dan Kekayaan Sekretariat Daerah Provinsi Maluku tahun 2011. Untuk itu, penulis melakukan wawancara mendalam kepada beberapa informan yang terkait langsung dengan pemeliharaan kendaraan dinas pada tahun 2011.

Dari uraian di atas menunjukkan bahwa dalam proses pemeliharaan kendaraan dinas terdapat beberapa biaya transaksi yaitu:

1. Biaya informasi seperti biaya pulsa telepon/HP dan pulsa internet

2. Biaya teknologi seperti biaya HP/pesawat telepon, komputer/laptop, printer dan perangkat lunak

3. Biaya administrasi seperti kertas, buku, map, pulpen, tinta printer, materai, bantal cap, amplop, hekter, isi hekter dan foto copy

4. Biaya operasional seperti biaya listrik, transportasi, konsumsi, dan honorarium pegawai.

Selanjutnya, penulis melalukan wawancara kepada pejabat pembuat komitmen dan pejabat pengadaan barang tentang perkiraan rincian biaya transaksi pemeliharaan kendaraan dinas pada tahun 2011 yang terdiri atas biaya informasi, biaya teknologi, biaya administrasi dan biaya operasional. Selanjutnya, penulis menghitung besarnya biaya transaksi tersebut. Adapun hasilnya sebagaimana pada uraian berikut ini: 


\section{Biaya Informasi}

Rincian besarnya biaya informasi terdiri atas biaya pulsa telpon, HP dan internet sebagaimana pada tabel berikut.

Rincian biaya informasi tersebut dapat dilihat pada tabel berikut.

Tabel 4.7 Biaya informasi pemeliharaan kendaraan dinas

\begin{tabular}{|c|l|r|r|}
\hline No & Komponen biaya & Volume & Biaya transaksi (Rp) \\
\hline \multirow{2}{*}{2} & Biaya telepon & $24 \times \mathrm{Rp} \mathrm{4.000}$ & 96.000 \\
\cline { 2 - 4 } 2 & Pulsa HP & $27 \times \mathrm{Rp} \mathrm{5.000}$ & 135.000 \\
\cline { 2 - 4 } 3 & Jasa internet & $7 \times \mathrm{Rp} 8.000$ & 56.000 \\
\hline \multicolumn{2}{|c|}{ Jumlah } & 287.000 \\
\hline
\end{tabular}

Sumber: Hasil wawancara kepada pejabat pembuat komitmen dan pejabat pengadaan barang

\section{Biaya Teknologi}

Rincian besarnya biaya teknologi terdiri atas biaya HP/pesawat telepon, perangkat internet, komputer/laptop dan printer sebagaimana pada tabel berikut.

Tabel 4.8 Biaya teknologi pemeliharaan kendaraan dinas

\begin{tabular}{|r|l|l|r|}
\hline No & \multicolumn{1}{|c|}{ Komponen biaya } & \multicolumn{1}{|c|}{ Volume } & Biaya transaksi (Rp) \\
\hline 1 & Pesawat telepon & $0,5 \% \times \mathrm{Rp} \mathrm{200.000}$ & 1.000 \\
\hline 2 & Pesawat HP & $0,5 \% \times \mathrm{Rp} \mathrm{2.000.000}$ & 10.000 \\
\hline 3 & Perangkat internet & $0,05 \% \times \mathrm{Rp} 4.000 .000$ & 2.000 \\
\hline 4 & Komputer & $0,5 \% \times \mathrm{Rp} \mathrm{3.000.000}$ & 15.000 \\
\hline 5 & Printer & $1 \% \times \mathrm{Rp} 1.000 .000$ & 10.000 \\
\hline \multicolumn{2}{|r|}{ Jumlah } & 38.000 \\
\hline
\end{tabular}

Sumber: Hasil wawancara kepada pejabat pembuat komitmen dan pejabat pengadaan barang

3. Biaya Administrasi

Rincian besarnya biaya administrasi terdiri atas biaya kertas, buku, map, alat tulis, tinta printer, amplop, bantal cap, hekter, isi hekter, materai, dan foto copy sebagaimana pada tabel berikut. 


\begin{tabular}{|r|l|l|r|}
\hline No & \multicolumn{1}{|c|}{ Komponen biaya } & \multicolumn{1}{|c|}{ Volume } & \multicolumn{1}{c|}{ Biaya transaksi (Rp) } \\
\hline 1 & Buku & $2 \times \mathrm{Rp} 15.000$ & 30.000 \\
\hline 2 & Kertas & 2 rim x Rp 45.000 & 90.000 \\
\hline 3 & Alat tulis & 1 paket & 30.000 \\
\hline 4 & Tinta printer & 1 paket & 50.000 \\
\hline 5 & Amplop & 1 paket & 20.000 \\
\hline 6 & Bantal cap & 1 buah x Rp 5.000 & 5.000 \\
\hline 7 & Hekter dan isinya & 1 paket & 10.000 \\
\hline 8 & Materai & $72 \times$ Rp 7.000 & 504.000 \\
\hline 9 & Foto copy dan penjilidan & 1 paket & 120.000 \\
\hline & \multicolumn{2}{|c}{ Jumlah } & 859.000 \\
\hline
\end{tabular}

Tabel 4.9 Biaya administrasi pemeliharaan kendaraan dinas

Sumber: Hasil wawancara kepada pejabat pembuat komitmen dan pejabat pengadaan barang

4. Biaya Operasional

Rincian besarnya biaya operasional terdiri atas biaya honorarium, konsumsi, transportasi dan listrik sebagaimana pada tabel berikut.

Tabel 4.10 Biaya operasional pemeliharaan kendaraan dinas

\begin{tabular}{|c|l|l|r|}
\hline No & \multicolumn{1}{|c|}{ Komponen biaya } & \multicolumn{1}{|c|}{ Volume } & Biaya transaksi (Rp) \\
\hline 1 & Honor KPA & 1 orang & 960.000 \\
\hline 2 & Honor PPK & 1 orang & 900.000 \\
\hline 3 & Honor Kepala & 1 orang & 900.000 \\
\hline 4 & Honor Sekretaris & 1 orang & 720.000 \\
\hline 5 & Honor Staf pendukung & 1 orang & 600.000 \\
\hline 6 & Konsumsi makanan besar & 34 orang x Rp 20.000 & 680.000 \\
\hline 7 & Konsumsi makanan kecil & 26 orang $\times$ Rp 8000 & 208.000 \\
\hline 8 & Transportasi & 29 kali $\times$ Rp 40.000 & 1.160 .000 \\
\hline 9 & Listrik & 1 paket & 340.000 \\
\hline & \multicolumn{2}{|c}{ Jumlah } & 6.468 .000 \\
\hline
\end{tabular}

Sumber: Hasil wawancara kepada pejabat pembuat komitmen dan pejabat pengadaan barang 
Berdasarkan hasil perhitungan jumlah dari setiap komponen biaya transaksi, maka disusunlah rekapitulasi biaya transaksi pemeliharaan kendaraan dinas pada Biro Keuangan dan Kekayaan Sekretariat Daerah Provinsi Maluku tahun 2011 sebagaimana pada tabel berikut ini.

Tabel 4.11 Rekapitulasi biaya transaksi pemeliharaan kendaraan dinas

\begin{tabular}{|c|l|r|}
\hline No & \multicolumn{1}{|c|}{ Komponen biaya } & \multicolumn{2}{|c|}{ Biaya transaksi (Rp) } \\
\hline 1 & Biaya informasi & 287.000 \\
\hline 2 & Biaya teknologi & 38.000 \\
\hline 3 & Biaya administrasi & 859.000 \\
\hline 4 & Biaya operasional & 6.468 .000 \\
\hline \multicolumn{2}{r|}{ Total } & 7.652 .000 \\
\hline
\end{tabular}

Berdasarkan rekapitulasi jumlah biaya transaksi berdasarkan komponen biaya transaksi di atas, maka dihitunglah rasio komponen biaya transaksi terhadap total biaya transaksi dengan menggunakan rumus dalam Marasabessy, A. Z. (2011):

$$
\mathrm{RBTi}=\frac{\mathrm{BTi}}{\mathrm{TBT}}
$$

Dimana:

RBTi = Rasio biaya transaksi komponen ke-i terhadap total biaya transaksi

$\mathrm{BTi}=$ jumlah biaya transaksi komponen ke-i

TBT = Total biaya transaksi

Tabel 4.12 Rasio komponen biaya transaksi terhadap total biaya transaksi

\begin{tabular}{|r|l|r|r|r|r|}
\hline No & Komponen biaya & Biaya transaksi (Rp) & \multicolumn{3}{|c|}{ Rasio } \\
\hline 1 & Biaya informasi & 287.000 & 0,038 & atau & 3,75 \\
\hline 2 & Biaya teknologi & 38.000 & 0,005 & atau & 0,50 \\
\hline 3 & Biaya administrasi & 859.000 & 0,112 & atau & 11,23 \\
\hline 4 & Biaya operasional & 6.468 .000 & 0,845 & atau & 84,53 \\
\hline \multicolumn{2}{c|}{ Total } & 7.652 .000 & 1,000 & atau & 100,00 \\
\hline
\end{tabular}


Untuk lebih jelasnya dapat dilihat pada gambar berikut ini.

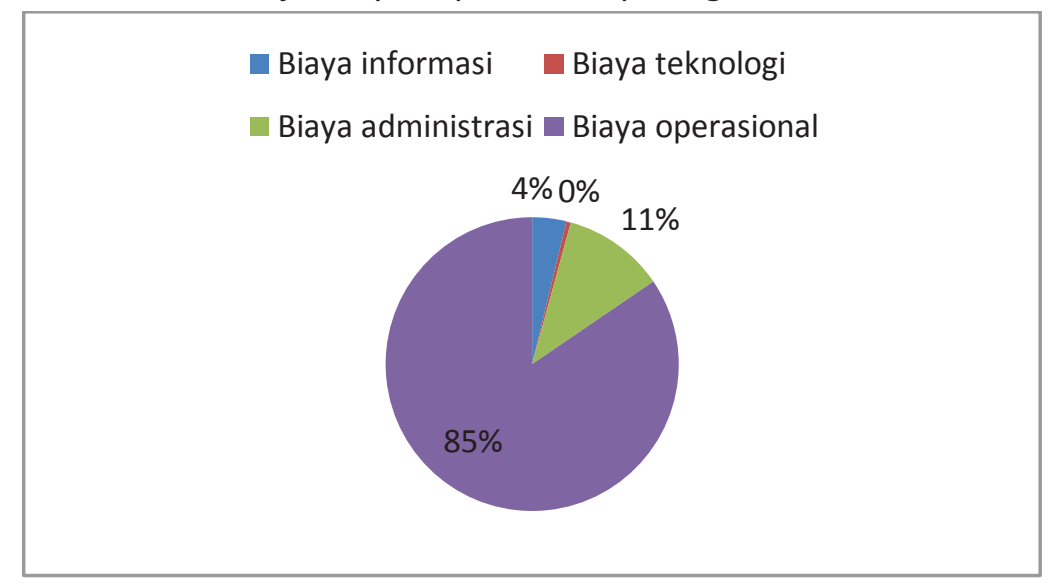

Gambar 4.2 Rasio komponen biaya transaksi terhadap total biaya transaksi pemeliharaan kendaraan dinas (Sumber: Hasil perhitungan rasio pada tabel 4.12 )

Dari tabel dan gambar di atas menunjukkan bahwa biaya dan rasio terbesar dari ke empat komponen biaya transaksi tersebut adalah biaya operasional sedang yang terkecil adalah biaya teknologi.

Adapun tinjauan dari perspektif teori efficiency economic value sebagaimana yang dicontohkan dalam proses pemeliharaan kendaraan dinas yaitu pada proses dico yang menunjukkan adanya asymetric information sehingga hal itu menyebabkan biaya transaksi yang dikeluarkan menjadi lebih besar dari yang seharusnya. Selain itu, berdasarkan hasil penelusuran penulis terhadap biaya salah satu sampel biaya pemeliharaan kendaraan dinas yaitu spooring balancing di bengkel mobil melalui wawancara terhadap karyawan bengkel diperoleh informasi bahwa biaya spooring balancing pada tahun 2011 adalah Rp 200.000 per mobil sementara biaya spooring balancing kenderaan dinas di Sekretariat Daerah Provinsi Maluku adalah Rp 275.000 per mobil. Ini menunjukkan bahwa biaya pemeliharaan kendaraan dinas khususnya spooring balancing kendaraan dinas di Sekretariat Daerah Provinsi Maluku adalah lebih tinggi dari biaya pasar. Jadi perspektif teori efficiency economic value terhadap biaya transaksi pemeliharaan kendaraan dinas pada Biro Keuangan dan Kekayaan Sekretariat Daerah Provinsi Maluku tahun 2011 adalah kurang efisien. 
Jika dilakukan efisiensi biaya spooring balancing dengan cara melaksanakan spooring balancing mobil pada bengkel yang lebih murah, maka terjadi penurunan harga dari Rp 275.000 menjadi Rp 200.000. Adapun prosentase biaya spooring balancing yang dapat diturunkan adalah sebesar $=\frac{275000-200000}{275000} \times 100 \%=27,3 \%$.

Ini mengindikasikan bahwa dapat dilakukan efisiensi biaya spooring balancing sebesar $27,3 \%$. 


\section{BAGIAN V}

\section{ANALISIS PROSES PENGADAAN ALAT TULIS KANTOR (ATK)}

Sistem pengadaan barang/jasa dapat dilakukan melalui metode lelang, swakelola, penunjukan langsung dan pengadaan langsung. Metode pemilihan penyedia pengadaan ATK pada Biro Keuangan dan Kekayaan Sekretariat Daerah Provinsi Maluku pada tahun 2011 adalah penunjukan langsung.

Dalam analisis ini, dicari alternatif metode pemilihan penyedia barang ATK lalu dibandingkan kelebihan dan kekurangannya sebagai dasar dalam penentuan kebijakan. Adapun tinjauan terhadap metode pemilihan penyedia barang/jasa berdasarkan Perpres No. 54 tahun 2010 sebagaimana pada uraian berikut.

Pelaksanaan pengadaan barang/jasa dapat dilakukan melalui penyedia barang atau swakelola. Pemilihan penyedia barang/jasa dilakukan dengan pelelangan yang terdiri atas pelelangan umum dan pelelangan sederhana, penunjukan langsung, pengadaan langsung, atau kontes/sayembara.

Dalam pasal 3 dinyatakan pelaksanaan pengadaan barang/jasa dilakukan melalui swakelola dan/atau pemilihan penyedia barang/jasa. Dalam Pasal 26 ayat 2 dinyatakan pekerjaan yang dapat dilakukan dengan swakelola meliputi:

a. pekerjaan yang bertujuan untuk meningkatkan kemampuan dan/atau memanfaatkan kemampuan teknis sumber daya manusia serta sesuai dengan tugas pokok K/L/D/I;

b. pekerjaan yang operasi dan pemeliharaannya memerlukan partisipasi langsung masyarakat setempat;

c. pekerjaan yang dilihat dari segi besaran, sifat, lokasi atau pembiayaannya tidak diminati oleh Penyedia Barang/Jasa;

d. pekerjaan yang secara rinci/detail tidak dapat dihitung/ditentukan terlebih dahulu, sehingga apabila dilaksanakan oleh Penyedia Barang/Jasa akan menimbulkan ketidakpastian dan risiko yang besar.

Dari uraian di atas menunjukkan bahwa kegiatan pengadaan ATK dan pemeliharaan kendaraan dinas pada Biro Keuangan dan Kekayaan Sekretariat Daerah Provinsi Maluku tidak cocok dilakukan dengan cara swakelola. 
Dalam Pasal 35 ayat (2) dinyatakan pemilihan penyedia barang/jasa dilakukan dengan:

a. Pelelangan yang terdiri atas pelelangan umum dan pelelangan sederhana;

b. Penunjukan langsung;

c. Pengadaan langsung; atau

d. Kontes/sayembara.

Sayembara adalah metode pemilihan penyedia jasa yang memperlombakan gagasan orisinal, kreativitas dan inovasi tertentu yang harga/biayanya tidak dapat ditetapkan berdasarkan harga satuan. Kontes adalah metode pemilihan penyedia barang yang memperlombakan barang/benda tertentu yang tidak mempunyai harga pasar dan yang harga/biayanya tidak dapat ditetapkan berdasarkan harga satuan.

Sebagaimana telah dijelaskan bahwa pengadaan ATK dan pemeliharaan kendaraan dinas tidak cocok dilakukan melalui swakelola, sayembara dan kontes.

Dalam pasal 31 dinyatakan:

(1) Pengadaan langsung dapat dilakukan terhadap pengadaan barang/pekerjaan konstruksi/jasa lainnya yang bernilai paling tinggi Rp 100.000.000,00 (seratus juta rupiah) dengan ketentuan sebagai berikut:

a. merupakan kebutuhan operasional K/L/D/I;

b. teknologi sederhana;

c. risiko kecil; dan/atau

d. dilaksanakan oleh penyedia barang/jasa usaha orang perseorangan dan/atau badan usaha kecil serta koperasi kecil, kecuali untuk paket pekerjaan yang menuntut kompetensi teknis yang tidak dapat dipenuhi oleh usaha mikro, usaha kecil dan koperasi kecil.

(2) Pengadaan langsung dilaksanakan berdasarkan harga yang berlaku di pasar kepada penyedia barang/pekerjaan konstruksi/jasa lainnya.

(3) Pengadaan langsung dilaksanakan oleh 1 (satu) Pejabat Pengadaan.

(4) PA/KPA dilarang menggunakan metode pengadaan langsung sebagai alasan untuk memecah paket Pengadaan menjadi beberapa paket dengan maksud untuk menghindari pelelangan.

Selanjutnya, dalam pasal 57 ayat (3) dinyatakan pemilihan penyedia barang/pekerjaan konstruksi/jasa lainnya dengan metode pengadaan langsung meliputi paling kurang tahapan sebagai berikut: 
a. $\quad$ survei harga pasar dengan cara membandingkan minimal dari 2 (dua) Penyedia Barang/Pekerjaan Konstruksi/Jasa Lainnya yang berbeda;

b. membandingkan harga penawaran dengan HPS; dan

c. klarifikasi teknis dan negosiasi harga/biaya.

Berdasarkan data laporan keuangan pembayaran pengadaan ATK pada Biro Keuangan dan Kekayaan Sekretariat Daerah Provinsi Maluku, biaya pengadaan ATK pada setiap triwulan sebesar Rp 38.570.210. Ini menunjukkan bahwa pengadaannya tidak dilakukan sekaligus melainkan dilakukan setiap triwulan. Selain itu, dari hasil wawancara dengan panitia pengadaan barang tahun 2011 menunjukkan bahwa terkadang ada ATK yang dibutuhkan yang tidak sama dengan rencana sebelumnya sehingga dilakukan perubahan sesuai dengan kebutuhan.

Sebagai pembanding, metode pemilihan penyedia barang ATK pada Politeknik Negeri Ujung Pandang melalui pengadaan langsung. Jadi metode pemilihan penyedia barang ATK dapat dilakukan melalui pengadaan langsung. Sehubungan dengan itu, perlu dianalisis perbandingan proses pengadaan ATK melalui penunjukan langsung dengan pengadaan langsung. Adapun perbandingan proses pengadaan ATK sebagaimana pada tabel berikut ini. 
Tabel 4. 13 Perbandingan proses pengadaan ATK

\begin{tabular}{|c|c|}
\hline $\begin{array}{l}\text { Proses pengadaan ATK melalui Penunjukan } \\
\qquad \text { langsung }\end{array}$ & Proses Pengadaan ATK melalui Pengadaan langsung \\
\hline $\begin{array}{l}\text { 4. Proses pemilihan penyedia barang } \\
\text { terdiri atas: } \\
\text { a. Undangan kepada peserta terpilih } \\
\text { dilampiri dokumen pengadaan } \\
\text { b. Pemasukan dokumen kualifikasi } \\
\text { c. Evaluasi kualifikasi } \\
\text { d. Pemberian penjelasan } \\
\text { e. Pemasukan dokumen penawaran } \\
\text { f. Evaluasi penawaran serta klarifikasi } \\
\text { g. Pan negosiasi teknis dan harga } \\
\text { h. Pengumuman pemenang } \\
\text { i. Penunjukan penyedia barang/jasa. } \\
\text { 5. Proses pelaksanaan pengadaan ATK } \\
\text { terdiri atas: } \\
\text { a. Pemeriksaan stok barang } \\
\text { b. Menaksir kebutuhan barang } \\
\text { c. Mengorder barang } \\
\text { d. Mengadakan/mendatangkan } \\
\text { 6. Pelaporan pengadaan ATK terdiri atas: } \\
\text { a. Penyusunan laporan } \\
\text { b. Penggandaan laporan } \\
\text { c. Penyerahan laporan } \\
\text { f. Membuat serah terima barang } \\
\text { g. Pembayaran barang } \\
\text { h. Membuat administrasi pengadaan } \\
\text { e. barang. }\end{array}$ & $\begin{array}{l}\text { 2. Proses pelaksanaan pengadaan ATK terdiri atas: } \\
\text { a. Pemeriksaan stok barang } \\
\text { b. Menaksir kebutuhan barang } \\
\text { c. Mengorder barang, } \\
\text { d. Mengadakan/mendatangkan barang } \\
\text { e. Pemeriksaan barang } \\
\text { f. Membuat serah terima barang } \\
\text { g. Pembayaran barang } \\
\text { h. Membuat administrasi pengadaan barang. } \\
\text { 3. Pelaporan pengadaan ATK terdiri atas: } \\
\text { a. Penyusunan laporan } \\
\text { b. Penggandaan laporan } \\
\text { c. Penyerahan laporan }\end{array}$ \\
\hline
\end{tabular}

Sumber: Hasil wawancara (diolah)

Dari tabel di atas menunjukkan bahwa pada dasarnya, proses pengadaan ATK melalui penunjukan langsung dengan pengadaan langsung berbeda dalam proses pemilihan penyedia barang sedangkan dalam proses pelaksanaan pengadaan barang dan pelaporan adalah sama. Jadi proses pengadaan ATK melalui penyedia barang dengan metode penunjukan langsung lebih panjang dari proses pengadaan ATK melalui 
penyedia barang dengan metode pengadaan langsung. Adapun perbandingan kelebihan/kekurangan proses pengadaan ATK melalui penunjukan langsung dengan pengadaan langsung sebagaimana pada tabel berikut ini.

Tabel 4.14 Perbandingan kelebihan/kekurangan proses pengadaan ATK melalui penunjukan langsung dengan pengadaan langsung

\begin{tabular}{|c|l|l|l|}
\hline No & \multicolumn{1}{|c|}{ Aspek (Indikator) } & Penunjukan langsung & $\begin{array}{c}\text { Pengadaan } \\
\text { langsung }\end{array}$ \\
\hline 1 & Panjang proses & Sedang & Pendek \\
\hline 2 & Lama kegiatan/ transaksi (waktu) & Sedang & Singkat \\
\hline 3 & Banyaknya pejabat pengadaan & Ganjil minimal 3 orang & 1 orang \\
\hline 4 & Tenaga (energi) yang digunakan & Sedang & Kurang \\
\hline 5 & Banyaknya biaya transaksi & Sedang & Kurang \\
\hline 6 & Harga beli barang & Sedang & Murah \\
\hline 7 & Kuantitas hasil barang/jasa & Sedang & Banyak \\
\hline 8 & Kualitas hasil barang & Sedang & Baik \\
\hline 9 & Ketepatan waktu pengadaan & Sedang & tepat \\
\hline 10 & Kesesuaian kebutuhan & Sedang & Sesuai \\
\hline
\end{tabular}

Berdasarkan perbandingan di atas menunjukkan bahwa dinilai dari aspek panjang proses, lama kegiatan, banyaknya pejabat pengadaan, tenaga (energi) yang digunakan, banyaknya biaya transaksi, harga beli barang, kuantitas hasil barang/jasa, kualitas hasil barang/jasa, ketepatan waktu pengadaan dan kesesuaian kebutuhan proses pengadaan ATK melalui pengadaan langsung lebih baik dari penunjukan langsung.

Untuk itu disarankan merubah metode pemilihan penyedia barang ATK dari penunjukan langsung menjadi pengadaan langsung.

\section{b. Analisis Proses Pemeliharaan Kendaraan Dinas}

Metode pemilihan penyedia jasa pemeliharaan kendaraan dinas pada Biro Keuangan dan Kekayaan Sekretariat Daerah Provinsi Maluku pada tahun 2011 adalah pelelangan umum. Dalam analisis ini, dicari alternatif metode pemilihan penyedia jasa pemeliharaan kendaraan dinas lalu dibandingkan kelebihan dan kekurangannya sebagai dasar dalam penentuan kebijakan.

Pelaksanaan pemeliharaan kendaraan dinas tidak dilakukan sekaligus melainkan sangat sesuai dengan situasi kapan kendaraan mengalami kerusakan. Selain itu, dari hasil wawancara dengan panitia pengadaan barang/jasa tahun 2011 menunjukkan 
bahwa terkadang kendaraan rusak di jalan dan membutuhkan waktu pelaksanaan pemeliharaan kendaraan yang cepat sehingga dilakukan perubahan sesuai dengan kebutuhan.

Berdasarkan uraian di atas dan dengan memperhatikan penyedia jasa pemeliharaan kendaraan dinas dimana jasanya merupakan kebutuhan operasional, risiko kecil, dilaksanakan oleh penyedia jasa usaha orang perseorangan dan/atau badan usaha kecil serta koperasi kecil, jumlah dan waktu kebutuhan yang bisa berubah dari perencanaan sehingga pemeliharaan kendaraan dinas bisa dilakukan melalui pengadaan langsung.

Jadi alternatif penyedia jasa pemeliharaan kendaraan dinas yang mungkin adalah pelelangan, penunjukan langsung dan pengadaan langsung.

Pelelangan tentu membutuhkan waktu, biaya dan tenaga jika dibandingkan dengan penunjukan langsung. Untuk itu, perlu dianalisis proses pemeliharaan kendaraan dinas melalui metode pelelangan umum dengan pengadaan langsung. Adapun perbandingan proses pemeliharaan kendaraan dinas melalui metode pelelangan umum dengan metode pengadaan langsung sebagaimana pada tabel berikut ini. 


\begin{tabular}{|c|c|}
\hline $\begin{array}{l}\text { Proses pemeliharaan kendaraan dinas melalui metode pelelangan } \\
\text { umum }\end{array}$ & $\begin{array}{c}\text { Proses pemeliharaan kendaraan } \\
\text { dinas melalui metode } \\
\text { pengadaan langsung }\end{array}$ \\
\hline $\begin{array}{l}\text { 1. Proses pemilihan penyedia jasa terdiri atas: } \\
\text { a. Pengumuman prakualifikasi; } \\
\text { b. Pendaftaran dan pengambilan dokumen kualifikasi; } \\
\text { c. Pemasukan dan evaluasi dokumen kualifikasi; } \\
\text { d. Pembuktian kualifikasi; } \\
\text { e. Penetapan hasil kualifikasi; } \\
\text { f. Pengumuman hasil kualifikasi; } \\
\text { g. Sanggahan kualifikasi; } \\
\text { h. Undangan; } \\
\text { i. Pengambilan dokumen pemilihan; } \\
\text { j. Pemberian penjelasan; } \\
\text { k. Pemasukan dokumen penawaran tahap I; } \\
\text { I. Pembukaan dokumen penawaran tahap I; } \\
\text { m. Evaluasi dokumen penawaran tahap I; } \\
\text { n. Penetapan peserta yang lulus evaluasi tahap I; } \\
\text { o. Pemberitahuan/ pengumuman peserta yg lulus evaluasi } \\
\text { tahap I; } \\
\text { p. Pemasukan dokumen penawaran tahap II; } \\
\text { q. Pembukaan dokumen penawaran tahap II; } \\
\text { r. Evaluasi dokumen penawaran tahap II; } \\
\text { s. Pembuatan berita acara hasil pelelangan; } \\
\text { t. Penetapan pemenang; } \\
\text { u. Pengumuman pemenang; } \\
\text { v. Sanggahan; } \\
\text { w. Sanggahan banding (apabila diperlukan); } \\
\text { x. Penunjukan penyedia barang/jasa } \\
\text { y. Undangan kepada peserta terpilih dilampiri dokumen } \\
\text { z. Pemasukan dokumen kualifikasi } \\
\text { aa. Evaluasi kualifikasi } \\
\text { bb. Pemberian penjelasan } \\
\text { cc. Pemasukan dokumen penawaran } \\
\text { dd. Evaluasi penawaran serta klarifikasi \&negosiasi teknis harga } \\
\text { ee. Penetapan pemenang } \\
\text { gf Penumuman pemenang } \\
\text { fonan penyedia barang/jasa. }\end{array}$ & $\begin{array}{l}\text { 1. Proses pemilihan penyedia } \\
\text { barang terdiri atas: } \\
\text { a. Survei harga pasar dengan } \\
\text { cara membandingkan } \\
\text { minimal dari } 2 \text { penyedia } \\
\text { jasa; } \\
\text { b. Membandingkan } \\
\text { harga/biaya penawaran } \\
\text { dengan harga perkiraan } \\
\text { sendiri (HPS) } \\
\text { c. Klarifikasi teknis dan } \\
\text { negosiasi harga. }\end{array}$ \\
\hline
\end{tabular}


Tabel 4. 15 Perbandingan proses pemeliharaan kendaraan dinas

2. Proses pelaksanaan pemeliharaan kendaraan dinas terdiri atas:

a. pejabat pengadaan barang/jasa memeriksa kerusakan kendaraan

b. Menaksir biaya perbaikan;

c. Koordinasi dengan penyedia jasa perbaikan (bengkel),

d. Pemeriksaan kendaraan;

e. Penentuan biaya dan kesepakatan harga;

f. Pelaksanaan perbaikan/pemeliharaan kendaraan;

g. Melaksanakan perbaikan; evaluasi hasil perbaikan;

h. Pembayaran dan pengambilan bukti pembayaran lalu diserahkan ke pejabat pengadaan barang.

3. Pelaporan pemeliharaan kendaraan dinas terdiri atas:
a. Penyusunan laporan
b. Penggandaan laporan
c. Penyerahan laporan

2. Proses pelaksanaan pemeliharaan kendaraan dinas terdiri atas:

a. pejabat pengadaan barang/jasa memeriksa kerusakan kendaraan

b. Menaksir biaya perbaikan;

c. Koordinasi dengan penyedia jasa perbaikan (bengkel),

d. Pemeriksaan kendaraan;

e. Penentuan biaya dan kesepakatan harga;

f. Pelaksanaan perbaikan/pemeliharaan kendaraan;

g. Melaksanakan perbaikan; evaluasi hasil perbaikan;

h. Pembayaran dan pengambilan bukti pembayaran lalu diserahkan ke pejabat pengadaan barang.

Pelaporan pemeliharaan kendaraan dinas terdiri atas:
a. Penyusunan laporan
b. Penggandaan laporan
c. Penyerahan laporan

Sumber: Hasil wawancara (diolah)

Dari tabel di atas menunjukkan bahwa pada dasarnya, proses pemeliharaan kendaraan dinas melalui pelelangan umum dengan pengadaan langsung berbeda dalam proses pemilihan penyedia jasa sedangkan dalam proses pelaksanaan pemeliharaan kendaraan dinas dan pelaporan adalah sama. Jadi proses pemeliharaan kendaraan dinas melalui penyedia barang dengan metode pelelangan umum lebih panjang dari melalui pengadaan langsung. Adapun perbandingan kelebihan/kekurangan proses pemeliharaan kendaraan dinas melalui pelelangan umum dengan pengadaan langsung pada tabel berikut ini. 
Tabel 4.16 Perbandingan kelebihan/kekurangan proses pemeliharaan kendaraan dinas melalui pelelangan umum dengan pengadaan langsung

\begin{tabular}{|c|l|l|l|}
\hline No & \multicolumn{1}{|c|}{ Aspek (Indikator) } & \multicolumn{1}{|c|}{ Pelelangan Umum } & \multicolumn{1}{|c|}{$\begin{array}{c}\text { Pengadaan } \\
\text { langsung }\end{array}$} \\
\hline 1 & Panjang proses & Panjang & Pendek \\
\hline 2 & Lama kegiatan/ transaksi (waktu) & Lama & Singkat \\
\hline 3 & Banyaknya pejabat pengadaan & Ganjil minimal 3 orang & 1 orang \\
\hline 4 & Tenaga (energi) yang digunakan & Banyak & Kurang \\
\hline 5 & Banyaknya biaya transaksi & Banyak & Kurang \\
\hline 6 & Biaya pemeliharaan & Mahal & Murah \\
\hline 7 & Kuantitas hasil barang/jasa & Mahal & Banyak \\
\hline 8 & Kualitas hasil barang/jasa & Kurang & Baik \\
\hline 9 & Ketepatan waktu pengadaan & Kurang & tepat \\
\hline 10 & Kesesuaian kebutuhan & Kurang & Sesuai \\
\hline
\end{tabular}

Berdasarkan perbandingan di atas menunjukkan bahwa ditinjau dari aspek proses panjang proses, lama kegiatan, banyaknya pejabat pengadaan, tenaga (energi) yang digunakan, banyaknya biaya transaksi, biaya pemeliharaan, kuantitas hasil barang/jasa, kualitas hasil barang/jasa, ketepatan waktu pengadaan dan kesesuaian kebutuhan menunjukkan bahwa pemeliharaan kendaraan dinas melalui pengadaan langsung lebih baik dari pelelangan umum. Untuk itu disarankan merubah metode pemilihan penyedia jasa pemeliharaan kendaraan dinas dari pelelangan umum menjadi pengadaan langsung.

\section{Tinjauan dari Perspektif Teori Informasi Asimetri (Asymmetric Information)}

Asymmetric information adalah perbedaan informasi yang dimiliki oleh service supply (aparat pelayanan) dengan informasi yang diketahui dan diterima oleh service demand (masyarakat yang dilayani) (Tietz, 2002: 121).

Dari hasil wawancara penulis terhadap informan menunjukkan bahwa terkadang dalam organisasi, terjadi asimetri informasi. Selain itu, dari contoh kasus asymmetric information dalam pembayaran hasil pengadaan ATK dan proses dico kenderaan dinas menyebabkan orang yang dilayani tidak puas bahkan kesal terhadap ketidak tepatan janji dan tidak adanya pemberitahuan penundaan. Ini menunjukkan bahwa asimetri informasi dapat menyebabkan kesalahan dan kelambatan dalam pelayanan. Selain itu, masyarakat yang dilayani menjadi kehilangan kepercayaan terhadap aparat pelayan dan ketidakpuasan. Ini berarti asimetri informasi dapat menyebabkan kualitas pelayanan 
rendah. Selanjutnya, jika terjadi asimetri informasi maka akan menyebabkan proses pelaksanaan pengadaan barang dan jasa menjadi panjang dan lama sehingga biaya transaksi dapat meningkat.

Dari uraian di atas menunjukkan bahwa semakin tinggi asymmetric information maka semakin rendah kualitas pelayanan organisasi kepada publik. Temuan penelitian ini sejalan dengan proposisi pertama dari penelitian ini yakni "semakin tinggi asymmetric information maka semakin rendah kualitas pelayanan organisasi kepada publik."

Temuan penelitian di atas sejalan dengan Teori asymmetric information sebagaimana diungkapkan oleh Tietz (2002: 121) bahwa kajian ilmu administrasi menjadikan teori asymmetric information sebagai kajian untuk melihat adanya hubungan yang saling terkait antara permintaan pelayanan (service demand) dengan penawaran pelayanan (service supply) untuk menghasilkan keseimbangan (equilibrium) pelayanan yang menguntungkan antara pemerintah dan publik.

Temuan penelitian di atas sejalan dengan Thaler (2003: 206) bahwa konsepsi teori asymmetric information merupakan suatu kegiatan secara langsung mengenai proses informasi yang dilakukan oleh pemerintah kepada publik tanpa mengabaikan pentingnya informasi sebagai sebuah peluang untuk memenuhi kepuasan publik. Atas dasar tersebut maka biaya transaksi suatu pelayanan tergantung pada muatan informasi yang diberikan oleh pihak pengambil kebijakan.

Temuan penelitian di atas sejalan dengan (Tood, Lebey, 2005: 223) adanya kepentingan dua belah pihak menimbulkan efek permintaan dan efek penawaran untuk menghasilkan keuntungan pembiayaan yang dapat digunakan secara operasional dalam pencapaian tujuan organisasi dan kepuasan publik

Ini berarti, biaya transaksi pelayanan menjadikan teori asymmetric information sebagai bagian penting di dalam menguraikan unsur-unsur yang berperan penting dalam rantai biaya transaksi. Semakin bagus pelayanan informasi yang diberikan oleh pemerintah, semakin berperan penting biaya transaksi yang dilakukan untuk memenuhi kepuasan publik.

Adapun jastifikasi penulis adalah bahwa dalam suatu organisasi dibutuhkan keterbukaan dan kejelasan informasi. Jika informasi tersebut terbuka dan dipahami oleh semua aparat pelayanan, maka aparat tersebut dapat bekerja dalam tim dengan baik sehingga pelayanan dapat berjalan lancar dan cepat. Sebaliknya, jika dalam suatu organisasi terjadi kesimpangsiuran informasi, maka pelayanan akan terganggu. 
Demikian halnya, jika terjadi keterbukaan dan kejelasan informasi dari aparat pelayanan terhadap publik, maka publik akan dapat dengan mudah memenuhi persyaratan dan ketentuan dalam pelayanan sehingga publik akan dapat mempersiapkan diri dalam rangka memenuhi pelayanan yang baik. Ini menunjukkan bahwa proposisi pertama yang menyatakan bahwa semakin tinggi asymmetric information, maka semakin rendah kualitas pelayanan organisasi kepada publik adalah terbukti.

Sehubungan dengan itu, maka diharapkan aparat pelayanan memberikan informasi yang terbuka, akurat dan adil kepada masyarakat dalam rangka meminimasi asymmetric information agar pelayanan dapat berjalan lancar. Hal ini dapat berdampak pada kepuasan masyarakat sehingga masyarakat dapat memberikan pelayanan yang baik kepada aparat.

\section{a. Tinjauan dari Perspektif Teori Opportunity Behavior}

Opportunity behavior adalah perilaku aparat pelayanan dalam mencari dan memanfaatkan peluang untuk memberikan pelayanan yang terbaik dan meminimasi biaya transaksi (Webley (2005: 155), Traub, (2000: 122), Tversky (2004: 74) dan Tietz (2002: 163))

Dari hasil wawancara penulis terhadap informan menunjukkan bahwa perilaku aparat (birokrasi) adalah adanya kemauan untuk memberikan pelayanan yang optimal kepada masyarakat tapi di sisi lain, dari contoh kasus dimana aparat pelayanan yang tidak memberitahukan penundaan penetapan janji dan tidak adanya upaya dari bagian pengadaan untuk cepat melayani masyarakat menunjukkan bahwa ada juga aparat pelayanan yang kurang memanfaatkan peluang untuk memberikan pelayanan yang baik kepada masyarakat. Jika orang yang melayani memiliki kemauan yang tinggi untuk memberikan pelayanan yang baik kepada masyarakat, maka pelayanan tersebut akan berjalan dengan baik. Perilaku berupa kemauan tersebut dibutuhkan dalam rangka memberikan pelayanan sebaik mungkin kepada publik. Perilaku aparat pelayanan yang memanfaatkan peluang untuk memberikan pelayanan yang berkualitas kepada publik akan berdampak pada tingginya kualitas pelayanan tersebut.

Dari uraian di atas menunjukkan bahwa aparat pelayanan yang memiliki Opportunity behavior yang tinggi akan dapat memberikan pelayanan yang berkualitas kepada publik. Perilaku tersebut akan meningkatkan kualitas pelayanan. Ini berarti semakin tinggi opportunity behavior, maka semakin 
tinggi kualitas pelayanan organisasi kepada publik. Temuan penelitian ini mendukung proposisi kedua dari penelitian ini yakni "Semakin tinggi opportunity behavior, maka semakin tinggi kualitas pelayanan organisasi kepada publik". Pelayanan yang baik akan menyebabkan proses pengadaan barang dan jasa berjalan dengan lancar dan cepat sehingga biaya transaksi bisa menurun.

Hasil penelitian ini sejalan dengan Webley (2005: 155) yang menyatakan keberhasilan suatu biaya transaksi dalam organisasi ditentukan dari perilaku birokrasi yang mencari peluang untuk memperoleh keuntungan. Ini berarti peluang menjadi penting dari perilaku pelaksana untuk menghasilkan pelayanan terbaik yang dengan sendirinya publik akan membayar dengan biaya transaksi yang sesuai tanpa menimbulkan adanya apresiasi yang negatif. Keuntungan bagi aparat bisa diraih dengan pelayanan yang baik dan tidak meminimalkan biaya. Jika biaya diminimasi tentu akan mengurangi keuntungan secara ekonomi bagi aparat birokrasi; Traub (2000: 122) bahwa sebuah organisasi berupaya mengembangkan perilaku aparat di dalam menerapkan teori opportunity behavior sebagai langkah kongkrit untuk memperbaiki pelayanan dalam menghasilkan biaya transaksi yang optimal. Tietz (2002: 163) bahwa organisasi dalam upaya memperoleh keuntungan optimal, berupaya memperbaiki opportunistic behavior sebagai penyikapan untuk menghasilkan optimalisasi keuntungan dengan meminimalkan biaya yang dikenakan. Tietz (2002: 163) memformulasikan opportunistic behavior sama dengan benefit optimalization (keuntungan optimal) dikurangi minimization cost (minimalisasi biaya) dengan rumus sebagai berikut.

$$
\mathrm{OB}=\mathrm{BO}-\mathrm{MC}
$$

Dimana: $\mathrm{OB}=$ opportunistic behavior, $\mathrm{BO}=$ benefit optimalization, $\mathrm{MC}=$ minimization cost

Hasil penelitian ini sejalan dengan hasil penelitian Hart, Silberd (2007) yang menunjukkan bahwa opportunistic behavior yang baik akan berdampak pada biaya transaksi pelayanan yang murah dan adil.

Adapun jastifikasi penulis adalah aparat pemerintah sebagai unsur penggerak organisasi pemerintahan memiliki kemauan dan usaha untuk memberikan pelayanan yang optimal tapi sangat sedikit kemauan dan usaha untuk meminimasi biaya transaksi. Pelayanan yang optimal akan memberikan kepuasan kepada masyarakat yang akan berdampak pada kepuasan 
masyarakat sehingga masyarakat mau membayar walau dengan harga tinggi. Hanya saja biaya transaksi yang minimal akan mengurangi pendapatan secara ekonomi bagi aparat yang terkait dengan pengadaan barang/jasa.

Optimalisasi opportunistic behavior tercapai bila pelayanan yang optimal dan biaya yang minimal. Untuk mencapai kondisi yang optimal tersebut maka harus ada kemauan dan komitmen dari pimpinan organisasi. Jika ada kemauan dan komitmen pimpinan akan menyebabkan aparat pelayanan bekerja secara maksimal dan meminimasi biaya. Bawahan tentu akan berusaha meminimasi biaya karena adanya kemauan dan komitmen dari pimpinan untuk meminimasi biaya tersebut.

Kualitas pelayanan sangat tergantung dari kemauan dan usaha dari aparat pelayanan untuk memberikan pelayanan yang berkualitas. Kemauan dan usaha tersebut menunjukkan opportunity behavior dari aparat pelayanan. Sehubungan dengan itu, semakin tinggi opportunity behavior, maka semakin tinggi kualitas pelayanan organisasi kepada publik. Jadi proposisi kedua yang menyatakan bahwa semakin tinggi opportunity behavior, maka semakin tinggi kualitas pelayanan organisasi kepada publik adalah terbukti.

Sehubungan dengan itu, maka diharapkan kepada aparat pelayanan agar memiliki kemauan dan usaha untuk memberikan pelayanan yang baik kepada publik.

\section{b. Tinjauan dari Perspektif Teori efficiency economic value}

Efficiency economic value adalah aktivitas yang dilakukan oleh aparat pelayanan dalam memberikan pelayanan dengan mempertimbangkan nilai secara ekonomis dari hasil pelayanan tersebut (Viscusi, WK. (2003: 79), Wittman, DA (2004: 246) dan Birl, Higgins (2003: 195)).

Dari hasil wawancara penulis terhadap informan menunjukkan bahwa ada kecenderungan biaya yang tinggi akan menyebabkan pelayanan berkualitas, atau pelayanan yang berkualitas diharapkan dibarengi dengan adanya insentif. Selain itu, dari contoh kasus menunjukkan bahwa dalam proses pembayaran ATK dan proses dico kendaraan dinas menunjukkan bahwa biaya transaksi kurang efisien. Terkadang ada kesengajaan dari aparat pelayanan untuk memperpanjang proses atau menunda-nunda pekerjaan agar timbul kemauan dari pihak yang dilayani memberikan uang pelicin untuk memperlancar dan mempercepat pekerjaan. Nilai ekonomi di sini bisa diukur 
dari waktu, biaya dan tenaga untuk melaksanakan proses pekerjaan. Efficiency economic value dapat dilakukan dengan cara penyederhanaan proses, memberikan pelayanan yang cepat dan baik kepada masyarakat. Efisiensi nilai ekonomi tersebut akan menyebabkan masyarakat yang dilayani merasa puas. Ini menunjukkan bahwa efisiensi nilai ekonomi dapat menyebabkan pelayanan semakin berkualitas.

Temuan penelitian ini menunjukkan bahwa aparat pelayanan melakukan efisiensi nilai ekonomi untuk mendapatkan keuntungan dengan memberikan pelayanan yang berkualitas tapi jarang melakukan minimasi biaya. Semakin tinggi efisiensi nilai ekonomi yang dilakukan oleh aparat semakin tinggi kualitas pelayanan yang diberikan kepada publik.

Temuan penelitian ini mendukung proposisi ketiga dari penelitian ini yakni "Semakin tinggi efficiency economic value, maka semakin tinggi kualitas pelayanan organisasi kepada publik."

Temuan penelitian ini sejalan dengan Ritzer (2005: 215) menyatakan keuntungan suatu organisasi tergantung pada efisiensi nilai ekonomis yang digunakan untuk memprediksi besarnya keuntungan dan kerugian yang ditimbulkan dari kegiatan transaksi pelayanan. Temuan ini sejalan pula dengan Viscusi, WK. (2003: 79) bahwa semakin banyak transaksi pelayanan yang terjadi dalam suatu organisasi semakin memberikan nilai tambah ekonomis bagi organisasi tersebut memperoleh keuntungan; Wittman, DA (2004: 246) bahwa semakin banyak manfaat dari transaksi yang diterapkan, upaya minimalisasi biaya semakin besar nilai ekonomis dilakukan oleh organisasi; Birl, Higgins (2003: 195) bahwa biaya transaksi yang tinggi dibarengi dengan pelayanan yang memuaskan menjadi nilai tambah bagi organisasi untuk maju dan berkembang.

Temuan penelitian ini pula mendukung hasil penelitian Hart, Silberd (2007) setiap kegiatan pelayanan kepada publik disesuaikan dengan besarnya pembiayaan yang dikeluarkan oleh pemerintah dalam kegiatan pelayanan dan opportunistic behavior yang baik akan berdampak pada biaya transaksi pelayanan yang murah dan adil. Mendukung pula hasil penelitian Harrison, William (2008) yang menunjukkan bahwa biaya transaksi dinilai efektif dan praktis untuk memotivasi publik memberikan biaya transaksi dalam kegiatan pelayanan untuk memperoleh sumber-sumber pendapatan birokrasi. Dalam melakukan suatu pelayanan ditemukan adanya hubungan rasional 
berdasarkan kepentingan, motif dan tujuan yang komparatif dengan tingkat pencapaian hasil yang diinginkan publik.

Adapun jastifikasi peneliti adalah secara organisasi pemerintahan, harusnya sumber daya manusia dari organisasi tersebut memberikan pelayanan sebaik mungkin dengan menggunakan sedikit biaya. Namun, dari sisi sumber daya manusia yakni banyak aparat pelayanan yang berusaha agar biaya diminimasi bahkan ada yang sengaja mencari cara agar biaya transaksi menjadi tinggi terutama pada biaya operasional sehingga ada keuntungan secara ekonomi bagi aparat pelayanan. Efisiensi nilai ekonomi dapat dilakukan dengan cara memanfaatkan dan memberdayakan semua sumber daya yang dimiliki. Upaya yang dilakukan aparat pelayanan dalam meningkatkan efisiensi nilai ekonomi adalah meningkatkan kualitas pelayanan tapi sangat jarang dilakukan minimasi biaya transaksi. Jadi pelayanan yang berkualitas biasanya dibarengi dengan biaya yang tinggi. Aparat pelayanan yang memiliki opportunistic behavior yang tinggi tentunya berusaha meningkatkan kualitas pelayanan. Pemanfaatan sumber daya secara baik akan meningkatkan kualitas pelayanan publik. Jadi semakin tinggi efficiency economic value, maka semakin tinggi kualitas pelayanan organisasi kepada publik.

Keterkaitan dengan efficiency economic value, maka proses pengadaan ATK dan pemeliharaan kendaraan dinas perlu dianalisis efisiensi dan efektivitasnya.

\section{1) Analisis Efisiensi Biaya Transaksi Pengadaan Alat Tulis Kantor (ATK) dan Pemeliharaan Kendaraan Dinas}

Efisiensi diukur melalui tingkat upaya (dana dan daya) yang dikeluarkan untuk melakukan transasi pengadaan alat tulis kantor (ATK) dan pemeliharaan kendaraan dinas dalam rangka mencapai hasil dan sasaran yang ditetapkan.

Teori efficiency economic value atau teori nilai ekonomi efisien merupakan sebuah teori untuk melihat tingkat pemanfaatan suatu kegiatan biaya transaksi dinilai dari aspek ekonomi berupa untung atau rugi. Ritzer (2005: 215) menyatakan keuntungan suatu organisasi tergantung pada efisiensi nilai ekonomis yang digunakan untuk memprediksi besarnya keuntungan dan kerugian yang ditimbulkan dari kegiatan transaksi pelayanan. Unsur-unsur penting dari suatu tahapan 
efisiensi nilai ekonomi adalah unsur transaksi, manfaat, keuntungan, kerugian dan kepentingan.

Efisiensi biaya adalah tingkat penggunaan anggaran berdasarkan jumlah untuk membiayai transaksi. Makin sedikit biaya yang dikeluarkan makin efisien. Jadi kriteria yang digunakan adalah kriteria biaya. Biaya tersebut bisa dikaitkan dengan harga pasar. Selain itu, dapat juga berdasarkan pertimbangan proses, waktu dan tenaga. Makin singkat proses, makin kurang waktu dan tenaga yang digunakan menunjukkan makin efisien. Jadi efisiensi dapat dilihat dari aspek biaya, waktu dan tenaga.

Untuk memilih proses pengadaan ATK yang paling efisien, maka dianalisis dua metode pemilihan penyedia barang yaitu penunjukan langsung dan pengadaan langsung. Adapun perbandingan biaya transaksinya menurut penulis adalah daya dan biaya yang dibutuhkan untuk transaksi pengadaan ATK sistem pengadaan langsung akan lebih murah dibanding penunjukan langsung. Perubahan dari penunjukan langsung menjadi pengadaan langsung akan mengakibatkan pengurangan daya dan dana transaksi pengadaan ATK. Adapun pengurangan daya sebagai berikut:

1. Prosesnya penunjukan langsung penyedia barang yang dimulai dari kegiatan mengundang penyedia ATK yang memenuhi syarat sampai pada evaluasi dan penentuan keputusan penyedia ATK dapat dikurangi

2. Jumlah pejabat pengadaan barang dapat dikurangi dari 3 orang menjadi 1 orang

Ini menunjukkan bahwa dari segi daya terjadi penurunan sehingga menjadi lebih efisien. Selanjutnya tinjauan dari sisi biaya, maka besarnya biaya transaksi dapat dikurangi. Adapun biaya transaksi yang dapat dikurangi adalah pada komponen biaya operasional yaitu

1. Jumlah pejabat pengadaan barang berkurang dari 3 orang menjadi 1 orang. Jadi terjadi penurunan honorarium sekretaris dan staf pendukung sebesar Rp 1.320.000

2. Konsumsi makanan besar dan konsumsi makanan kecil bisa berkurang 50 \% sehingga terjadi penurunan sebesar Rp 180.000 . 
Dari uraian di atas menunjukkan bahwa jika dilakukan perubahan dari sistem penunjukan langsung menjadi pengadaan langsung akan terjadi penurunan biaya transaksi sebesar Rp 1.500.000. Jadi total biaya transaksi pengadaan ATK akan menurun dari Rp 5.567.000 menjadi Rp 4.067.000.

Berdasarkan perhitungan di atas, maka diperoleh biaya minimal sebesar Rp 4.067.000 dan biaya sebenarnya dikeluarkan Rp 5.567.000. Jadi besarnya tingkat efisiensi biaya transaksi pengadaan ATK adalah

$$
\text { Tingkat Efisiensi }=\frac{4.067 .000}{5.567 .000} \times 100 \%=73 \%
$$

Dari uraian di atas menunjukkan bahwa tingkat efisiensi biaya transaksi dalam proses pengadaan ATK pada Biro Keuangan dan Kekayaan Sekretariat Daerah Provinsi Maluku

Berdasarkan uraian di atas, maka pengadaan ATK sebaiknya dilakukan melalui pengadaan langsung dalam rangka meningkatkan efisiensi proses dan biaya pengadaan ATK.

Selanjutnya, untuk menganalisis efisiensi kegiatan pemeliharaan kendaraan dinas pada Biro Keuangan dan Kekayaan Sekretariat Daerah Provinsi Maluku dibandingkan dua alternatif proses pemilihan penyedia jasa pemeliharaan kendaraan dinas yaitu melalui pelelangan umum dan pengadaan langsung. Sudah diuraikan sebelumnya bahwa biaya transaksi pada sistem pengadaan langsung lebih rendah dari sistem penunjukan langsung.

Sehubungan dengan itu, maka untuk memilih sistem yang paling efisien, maka ditinjau dua sistem yaitu pelelangan umum dan pengadaan langsung. Adapun perbandingan biaya transaksinya menurut penulis adalah daya dan biaya yang dibutuhkan untuk transaksi pemeliharaan kendaraan dinas sistem pengadaan langsung akan lebih murah dibanding pelelangan umum. Perubahan dari pelelangan umum menjadi pengadaan langsung akan mengakibatkan pengurangan daya dan dana transaksi pemeliharaan kendaraan dinas. Adapun pengurangan daya sebagai berikut:

1. Prosesnya pelelangan umum yang dimulai dari kegiatan pengumuman di media elektronik dan di kantor sampai pada evaluasi dan penentuan keputusan pemenang lelang ditiadakan. Jadi ada beberapa proses atau aktivitas yang berkurang 
2. Jumlah pejabat pengadaan barang dapat dikurangi dari 3 orang menjadi 1 orang

Ini menunjukkan bahwa dari segi daya terjadi penurunan sehingga menjadi lebih efisien. Selanjutnya tinjauan dari sisi biaya, maka besarnya biaya transaksi dapat dikurangi. Adapun biaya transaksi yang dapat dikurangi adalah pada komponen biaya operasional yaitu

1. Jumlah pejabat pengadaan barang/jasa berkurang dari 3 orang menjadi 1 orang. Jadi terjadi penurunan honorarium sekretaris dan staf pendukung sebesar $\mathrm{Rp} 1.320 .000$

2. Konsumsi makanan besar dan konsumsi makanan kecil bisa berkurang $60 \%$ sehingga terjadi penurunan sebesar Rp 532.800 .

Dari uraian di atas menunjukkan bahwa jika dilakukan perubahan dari sistem pelelangan umum langsung menjadi pengadaan langsung akan terjadi penurunan biaya transaksi sebesar $\mathrm{Rp} 1.852 .800$. Jadi total biaya transaksi pemeliharaan kendaraan dinas akan menurun dari Rp 7.652.000 menjadi Rp 5.799.200.

Berdasarkan perhitungan di atas, maka diperoleh biaya minimal sebesar Rp 5.799.200 dan biaya sebenarnya dikeluarkan Rp 7.652.000. Jadi besarnya tingkat efisiensi biaya transaksi pemeliharaan kendaraan dinas adalah

$$
\text { Tingkat Efisiensi }=\frac{5.799 .200}{7.652 .000} \times 100 \%=76 \%
$$

Berdasarkan uraian di atas, maka pemeliharaan kendaraan dinas sebaiknya dilakukan melalui pengadaan langsung dalam rangka meningkatkan efisiensi proses dan biaya transaksi pemeliharaan kendaraan dinas.

\section{Analisis Efektivitas Biaya Transaksi Pengadaan Alat Tulis Kantor (ATK) dan Pemeliharaan Kendaraan Dinas}

Efektivitas biaya adalah tingkat penggunaan anggaran berdasarkan penggunaannya yang tepat dalam rangka pengadaan alat tulis kantor (ATK). Dari data dokumen pelaksanaan anggaran untuk kegiatan pengadaan ATK pada Biro Keuangan dan Kekayaan Sekretariat Daerah Provinsi Maluku menunjukkan bahwa semua anggaran pengadaan ATK pada tahun 2011 yang berjumlah Rp 154.281.000 habis 
dipakai untuk pengadaan ATK. Jadi tingkat penggunaan anggaran adalah $100 \%$. Ini menunjukkan bahwa efektivitas dari anggaran pengadaan ATK adalah $100 \%$ jika ditinjau dari tingkat penggunaan anggaran.

Semua biaya transaksi yang dikeluarkan diperuntukkan bagi kegiatan pengadaan ATK. Selain itu, dari hasil perbandingan kelebihan dan kekurangan proses pengadaan ATK melalui pemilihan penyedia barang dengan metode penunjukan langsung dan pengadaan langsung menunjukkan bahwa jika dilakukan pengadaan langsung maka harga barang lebih murah sehingga dengan menggunakan anggaran yang ada lebih banyak barang yang bisa dibeli, kualitas barang yang dibeli bisa lebih baik, ketepatan waktu pengadaan barang lebih tepat dan lebih sesuai jenis barang yang dibutuhkan. Ini menunjukkan bahwa lebih efektif pengadaan langsung dari pada penunjukan langsung. Ini berarti efektivitas biaya transaksi pengadaan ATK selama ini masih bisa ditingkatkan dengan cara penunjukan langsung. Ini berarti biaya transaksi pengadaan ATK selama ini tidak efektif.

Sehubungan dengan itu, maka diharapkan dilakukan perubahan pemilihan penyedia barang ATK dari penunjukan langsung menjadi pengadaan langsung dalam rangka meningkatkan efektivitas.

Selanjutnya, berdasarkan laporan penggunaan dana untuk biaya pemeliharaan kendaraan dinas pada Biro Keuangan dan Kekayaan Sekretariat Daerah Provinsi Maluku menunjukkan bahwa semua anggaran pemeliharaan kendaraan dinas pada tahun 2011 yang berjumlah $\mathrm{Rp} 277.795 .000$ habis dipakai untuk pemeliharaan kendaraan dinas. Jadi tingkat penggunaan anggaran adalah $100 \%$. Ini menunjukkan bahwa efektivitas dari anggaran pemeliharaan kendaraan dinas $100 \%$ jika ditinjau dari tingkat penggunaan anggaran.

Menurut penulis bahwa pemeliharaan kendaraan dinas melalui lelang umum tidak efektif karena ada kondisi dimana kerusakan kendaraan tidak diduga sebelumnya sehingga perbaikannya tidak dapat dilelang. Demikian halnya penggantian oli kendaraan terkadang situasional. Dengan demikian dari waktu perbaikan akan lebih cepat dilaksanakan jika menggunakan pengadaan langsung dari pada lelang. Demikian halnya ketersediaan kendaraan dinas yang layak pakai akan lebih tersedia jika menggunakan pengadaan langsung dari pada lelang umum.

Efektivitas dari biaya transaksi sangat penting dalam rangka memperlancar pekerjaan pegawai sehingga pelayanan kepada masyarakat bisa menjadi lebih baik. Hal ini sejalan dengan pandangan Gareth (2004: 77) bahwa pada prinsipnya teori biaya transaksi bertujuan untuk meminimalkan biaya dari kegiatan penyesuaian pelayanan 
untuk menghasilkan kegiatan yang efektif, efisien dan ekonomis. Pandangan Karel mempunyai korelasi yang erat dari apa yang dikemukakan oleh Gareth (2004: 90) yang menyatakan bahwa biaya transaksi adalah biaya yang berperan penting dalam menciptakan peluang organisasi untuk memberikan pelayanan yang terbaik. Ini berarti esensi dari biaya dalam berbagai kegiatan pelayanan pembiayaan atau penganggaran berperan penting dalam memperlancar pencapaian suatu tujuan organisasi. Seperti halnya dalam pandangan Gareth (2004: 95) bahwa biaya transaksi dalam suatu organisasi dikelola dengan baik melalui tahapan efisiensi, efektivitas dan ekonomis dalam pembiayaan.

Sehubungan dengan uraian di atas, maka penulis menilai bahwa biaya transaksi pemeliharaan kendaraan dinas pada Biro Keuangan dan Kekayaan Sekretariat Daerah Provinsi Maluku belum efektif. Sehubungan

Sehubungan dengan itu, maka diharapkan dilakukan perubahan pemilihan penyedia jasa pemeliharaan kendaraan dinas dari pelelangan umum menjadi pengadaan langsung dalam rangka meningkatkan efektivitas biaya transaksi. 


\section{BAGIAN VI \\ PERSPEKTIF PROSES PENGADAAN \\ BARANG DAN JASA}

Menurut LKPP (2010), pengadaan barang/jasa pemerintah yang selanjutnya disebut dengan pengadaan barang/jasa adalah kegiatan untuk memperoleh barang/jasa oleh kementerian/lembaga/satuan kerja perangkat daerah/ Institusi lainnya yang prosesnya dimulai dari perencanaan kebutuhan sampai diselesaikannya seluruh kegiatan untuk memperoleh barang/jasa. Dalam hal ini proses yang dimaksud diatur dalam Peraturan Presiden Nomor 54 Tahun 2010 tentang Pengadaan Barang/jasa Pemerintah.

Barang, yaitu setiap benda baik berwujud maupun tidak berwujud, bergerak maupun tidak bergerak, yang dapat diperdagangkan, dipakai, dipergunakan atau dimanfaatkan oleh pengguna barang. Jasa terbagi atas dua macam yaitu konsultansi dan jasa lainnya. Jasa konsultansi adalah jasa layanan profesional yang membutuhkan keahlian tertentu diberbagai bidang keilmuan yang mengutamakan adanya olah pikir (brain ware). Jasa Lainnya, yaitu jasa yang membutuhkan kemampuan tertentu yang mengutamakan keterampilan (skill ware) dalam suatu sistem tata kelola yang telah dikenal luas di dunia usaha untuk menyelesaikan suatu pekerjaan atau segala pekerjaan dan/atau pengadaan jasa selain jasa konsultansi, pelaksanaan pekerjaan konstruksi dan pengadaan barang.

Menurut Pusat Jaminan Mutu (2012), pengadaan barang adalah usaha yang dilakukan untuk mengadakan barang yang dibutuhkan untuk mendukung proses kerja yang dilakukan, sedang pemeliharaan barang adalah usaha yang dilakukan dengan cara mengontrol, mengecek dan memelihara semua barang yang dimiliki. Pemeliharaan barang dapat dibedakan menjadi 2 yaitu:

a. Pemeliharaan ringan adalah pemeliharaan secara rutin dan berkala terhadap barang yang dimiliki sesuai dengan jenis dan kondisi aset.

b. Pemeliharaan berat adalah pemeliharaan terhadap barang yang mengalami kerusakan dan menuntut segera perbaikan demi kelancaran proses kerja.

Dalam LKPP (2010) dan Perpres No. 54 Tahun 2010, terdapat sejumlah prinsip yang harus dijadikan dasar dalam melaksanakan proses pengadaan barang/jasa diantaranya efisien dan efektif. Efisiensi pengadaan barang/jasa diukur terhadap seberapa besar upaya yang dilakukan untuk memperoleh barang/jasa dengan 
spesifikasi yang sudah ditetapkan. Upaya yang dimaksud mencakup dana dan daya yang dikeluarkan untuk memperoleh barang/jasa. Semakin kecil upaya yang diperlukan maka dapat dikatakan bahwa proses pengadaan semakin efisien.

Menurut Ansari, Muhammad Sadiq (2006) efisiensi biaya diartikan sebagai rasio antara biaya minimum dengan biaya sebenarnya yang dikeluarkan oleh perusahaan untuk menghasilkan sejumlah produksi tertentu. Hal ini dapat dinyatakan dengan rumus:

$$
\text { Efisiensi }=\frac{\text { Biaya minimum }}{\text { Biaya yang sebenarnya dikeluarkan }} \times 100 \%
$$

Pengadaan barang/jasa pemerintah yang efisien dan efektif sangat diperlukan bagi ketersediaan barang/jasa yang terjangkau dan berkualitas, sehingga akan berdampak pada peningkatan pelayanan publik. Untuk itu, dalam proses pengadaan barang/jasa hendaknya selalu diupayakan memenuhi prinsip efisiensi dan efektivitas.

Efektifitas pengadaan diukur terhadap seberapa jauh barang/jasa yang diperoleh dari proses pengadaan dapat mencapai spesifikasi yang sudah ditetapkan. Menurut Alma, Buchari $(2010,86)$ bahwa efektivitas adalah tingkat manakah tujuan itu sudah dicapai dalam arti kualitas dan kuantitas. Selanjutnya, menurut Wibisono, Agus (2010) bahwa efektif yaitu suatu pencapaian tujuan secara tepat atau memilih tujuan-tujuan yang tepat dari serangkaian alternatif. Efektifitas bisa juga diartikan sebagai pengukuran keberhasilan dalam pencapaian tujuan-tujuan yang telah ditentukan. Sedangkan efisien yaitu penggunaan sumber daya secara minimum guna pencapaian hasil yang optimum. Efisiensi menganggap bahwa tujuan-tujuan yang benar telah ditentukan dan berusaha untuk mencari cara-cara yang paling baik untuk mencapai tujuan-tujuan tersebut. Efisiensi hanya dapat dievaluasi dengan penilaian-penilaian relatif, membandingkan antara masukan dan keluaran yang diterima.

Berdasarkan kajian terhadap Perpres Nomor 54 Tahun 2010 Tentang Pengadaan Barang Pemerintah ditemukan beberapa poin yang dapat menjadi pedoman dalam proses pengadaan barang/jasa pada tahun 2011 khususnya yang berkaitan dengan pengadaan ATK dan pemeliharaan kendaraan dinas yaitu:

1. Pemilihan penyedia barang/jasa dapat dilakukan melalui pelelangan umum, pelelangan terbatas, pelelangan sederhana dan penunjukan langsung:

2. Pelelangan umum adalah metode pemilihan penyedia barang/pekerjaan konstruksi/jasa lainnya untuk semua pekerjaan yang dapat diikuti oleh semua penyedia barang/pekerjaan konstruksi/jasa lainnya yang memenuhi syarat. 
3. Pelelangan sederhana: pelelangan sederhana adalah metode pemilihan penyedia barang/jasa Lainnya untuk pekerjaan yang bernilai paling tinggi $\mathrm{Rp}$ 200.000.000,00 (dua ratus juta rupiah) (Pasal 1 ayat 25).

Dimana:

- Penyedia barang/jasa adalah badan usaha atau orang perseorangan yang menyediakan barang/ pekerjaan konstruksi/jasa konsultansi/ jasa lainnya (Pasal 11ayatt 12)

- Barang adalah setiap benda baik berwujud maupun tidak berwujud, bergerak maupun tidak bergerak, yang dapat diperdagangkan, dipakai, dipergunakan atau dimanfaatkan oleh pengguna barang (Pasal 1 ayat 14)

4. Swakelola: adalah pengadaan barang/jasa dimana pekerjaannya direncanakan, dikerjakan dan/atau diawasi sendiri oleh K/L/D/I sebagai penanggung jawab anggaran, instansi pemerintah lain dan/atau kelompok masyarakat (Pasal 1 ayat 20)

5. Penunjukan langsung: adalah metode pemilihan penyedia barang/jasa dengan cara menunjuk langsung 1 (satu) penyedia barang/jasa. (pasal 1 ayat 31)

6. Pengadaan langsung: Adalah pengadaan barang/jasa langsung kepada penyedia barang/jasa, tanpa melalui pelelangan/seleksi/penunjukan langsung (Pasal 1 ayat 32)

7. Layanan pengadaan secara elektronik yang selanjutnya disebut LPSE adalah unit kerja K/L/D/I yang dibentuk untuk menyelenggarakan sistem pelayanan pengadaan barang/jasa secara elektronik (Pasal 1 ayat 38).

8. E-Tendering adalah tata cara pemilihan penyedia barang/jasa yang dilakukan secara terbuka dan dapat diikuti oleh semua penyedia barang/jasa yang terdaftar pada sistem pengadaan secara elektronik dengan cara menyampaikan 1 (satu) kali penawaran dalam waktu yang telah ditentukan (Pasal 1 ayat 39).

9. Katalog elektronik atau E-Catalogue adalah sistem informasi elektronik yang memuat daftar, jenis, spesifikasi teknis dan harga barang tertentu dari berbagai penyedia barang/jasa pemerintah (Pasal 1 ayat 40).

10. E-Purchasing adalah tata cara pembelian barang/jasa melalui sistem katalog elektronik (Pasal 1 ayat 41).

11. Pelaksanaan pengadaan barang/jasa dilakukan melalui: 

a. Swakelola; dan/atau
b. Pemilihan penyedia barang/jasa (pasal 3).

12. Pengadaan barang/jasa menerapkan prinsip-prinsip sebagai berikut efisien; efektif; transparan, terbuka; bersaing; adil/tidak diskriminatif; dan akuntabel (Pasal 5).

13. Para pihak yang terkait dalam pelaksanaan pengadaan barang/jasa harus mematuhi etika sebagai berikut (pasal 6):

a. melaksanakan tugas secara tertib, disertai rasa tanggung jawab untuk mencapai sasaran, kelancaran dan ketepatan tercapainya tujuan pengadaan barang/jasa;

b. bekerja secara profesional dan mandiri, serta menjaga kerahasiaan dokumen pengadaan barang/jasa yang menurut sifatnya harus dirahasiakan untuk mencegah terjadinya penyimpangan dalam pengadaanbarang /Jasa;

c. tidak saling mempengaruhi baik langsung maupun tidak langsung yang berakibat terjadinya persaingan tidak sehat;

d. menerima dan bertanggung jawab atas segala keputusan yang ditetapkan sesuai dengan kesepakatan tertulis para pihak;

e. menghindari dan mencegah terjadinya pertentangan kepentingan para pihak yang terkait, baik secara langsung maupun tidak langsung dalam proses pengadaan barang/jasa;

f. menghindari dan mencegah terjadinya pemborosan dan kebocoran keuangan negara dalam Pengadaan Barang/Jasa;

g. menghindari dan mencegah penyalahgunaan wewenang dan/atau kolusi dengan tujuan untuk keuntungan pribadi, golongan atau pihak lain yang secara langsung atau tidak langsung merugikan negara; dan

h. tidak menerima, tidak menawarkan atau tidak menjanjikan untuk memberi atau menerima hadiah, imbalan, komisi, rabat dan berupa apa saja dari atau kepada siapapun yang diketahui atau patut diduga berkaitan dengan pengadaan barang/jasa.

14. Dalam Pasal 7 dinyatakan: 
(1) Organisasi pengadaan barang/jasa untuk pengadaan melalui penyedia barang/jasa terdiri atas:
a. PA/KPA;
b. PPK;
c. ULP/Pejabat pengadaan; dan
d. Panitia/pejabat penerima hasil pekerjaan.

(2) Organisasi pengadaan barang/jasa untuk pengadaan melalui swakelola terdiri atas:
a. PA/KPA;
b. PPK; dan
c. Panitia/pejabat penerima hasil pekerjaan.

(3) PPK dapat dibantu oleh tim pendukung yang diperlukan untuk pelaksanaan pengadaan barang/jasa.

(4) Perangkat organisasi ULP ditetapkan sesuai kebutuhan yang paling kurang terdiri atas:
a. kepala;
b. sekretariat
c. staf pendukung; dan
d. kelompok kerja

15. Dalam pasal 8 dinyatakan:

(1) PA memiliki tugas dan kewenangan sebagai berikut:

a. menetapkan rencana umum pengadaan;

b. mengumumkan secara luas rencana umum pengadaan paling kurang di website $\mathrm{K} / \mathrm{L} / \mathrm{D} / \mathrm{l}$;

c. menetapkan PPK;

d. menetapkan pejabat pengadaan;

e. menetapkan panitia/pejabat penerima hasil pekerjaan;

f. menetapkan: 
1) pemenang pada pelelangan atau penyedia pada penunjukan langsung untuk paket pengadaan barang/pekerjaan konstruksi/ jasa lainnya dengan nilai diatas Rp.100.000.000.000,00 (seratus miliar rupiah); atau

2) pemenang pada seleksi atau penyedia pada penunjukan langsung untuk paket pengadaan jasa konsultansi dengan nilai diatas Rp10.000.000.000,00 (sepuluh miliar rupiah).

g. mengawasi pelaksanaan anggaran;

h. menyampaikan laporan keuangan sesuai dengan ketentuan peraturan perundang-undangan;

i. menyelesaikan perselisihan antara PPK dengan ULP/Pejabat Pengadaan, dalam hal terjadi perbedaan pendapat; dan

j. mengawasi penyimpanan dan pemeliharaan seluruh Dokumen Pengadaan Barang /Jasa.

16. Dalam pasal 9 dinyatakan bahwa atas dasar pertimbangan besaran beban pekerjaan atau rentang kendali organisasi, maka PA pada Kementerian/ Lembaga/Institusi pusat lainnya menetapkan seorang atau beberapa orang KPA (Kuasa Pengguna Anggaran);

17. Dalam pasal 10 dinyatakan bahwa KPA pada kementerian/Lembaga/Institusi pusat lainnya merupakan pejabat yang ditetapkan oleh PA

18. Dalam pasal 11 dinyatakan

(1) PPK memiliki tugas pokok dan kewenangan sebagai berikut:

a. menetapkan rencana pelaksanaan Pengadaan Barang/Jasa yang meliputi:

1) spesifikasi teknis Barang/Jasa;

2) Harga Perkiraan Sendiri (HPS); dan

3) rancangan Kontrak.

b. menerbitkan surat penunjukan penyedia barang/jasa;

c. menandatangani Kontrak;

d. melaksanakan kontrak dengan penyedia barang/jasa;

e. mengendalikan pelaksanaan kontrak; 
f. melaporkan pelaksanaan/penyelesaian Pengadaan Barang/Jasa kepada PA/KPA;

g. menyerahkan hasil pekerjaan pengadaan barang/jasa kepada PA/KPA dengan berita acara penyerahan;

h. melaporkan kemajuan pekerjaan termasuk penyerapan anggaran dan hambatan pelaksanaan pekerjaan kepada PA/KPA setiap triwulan; dan

i. menyimpan dan menjaga keutuhan seluruh dokumen pelaksanaan Pengadaan Barang/ Jasa.

19. Dalam pasal 15 dinyatakan:

(1) Pemilihan penyedia barang/jasa dalam ULP dilakukan oleh kelompok kerja.

(2) Keanggotaan ULP wajib ditetapkan untuk:

a. Pengadaan barang/pekerjaan konstruksi/jasa lainnya dengan nilai diatas Rp100.000.000,00 (seratus juta rupiah);

b. Pengadaan jasa konsultansi dengan nilai diatas Rp50.000.000,00 (lima puluh juta rupiah).

(3) Anggota kelompok kerja berjumlah gasal beranggotakan paling kurang 3 (tiga) orang dan dapat ditambah sesuai dengan kompleksitas pekerjaan.

20. Dalam Pasal 16 ayat (3) dinyatakan pengadaan langsung dilaksanakan oleh 1 (satu) orang pejabat pengadaan.

21. Dalam Pasal 17 ayat (2) dinyatakan tugas pokok dan kewenangan ULP/pejabat pengadaan meliputi:

a. menyusun rencana pemilihan penyedia barang/jasa;

b. menetapkan dokumen pengadaan;

c. menetapkan besaran nominal jaminan penawaran;

d. mengumumkan pelaksanaan pengadaan barang/jasa di website K/L/D/I masing-masing dan papan pengumuman resmi untuk masyarakat serta menyampaikan ke LPSE untuk diumumkan dalam portal pengadaan nasional;

e. menilai kualifikasi penyedia barang/jasa melalui prakualifikasi atau pasca kualifikasi; 
f. melakukan evaluasi administrasi, teknis dan harga terhadap penawaran yang masuk;

i. membuat laporan mengenai proses dan hasil pengadaan kepada Menteri/Pimpinan Lembaga/Kepala Daerah/Pimpinan Institusi; dan

j. memberikan pertanggungjawaban atas pelaksanaan kegiatan Pengadaan Barang/Jasa kepada PA/KPA.

22. Dalam Pasal 18 ayat (4) dinyatakan panitia/pejabat penerima hasil pekerjaan mempunyai tugas pokok dan kewenangan untuk:

a. melakukan pemeriksaan hasil pekerjaan Pengadaan Barang/Jasa sesuai dengan ketentuan yang tercantum dalam Kontrak;

b. menerima hasil Pengadaan Barang/Jasa setelah melalui pemeriksaan/ pengujian; dan

c. membuat dan menandatangani berita acara serah terima hasil pekerjaan.

23. Dalam Pasal 22 dinyatakan:

(1) PA menyusun rencana umum pengadaan barang/jasa sesuai dengan kebutuhan pada $\mathrm{K} / \mathrm{L} / \mathrm{D} / \mathrm{I}$ masing-masing.

(2) Rencana umum pengadaan barang/jasa sebagaimana dimaksud pada ayat (1) meliputi:

a. kegiatan dan anggaran Pengadaan Barang/Jasa yang akan dibiayai oleh K/L/D/I sendiri; dan/atau

b. kegiatan dan anggaran pengadaan barang/jasa yang akan dibiayai berdasarkan kerja sama antar K/L/D/I secara pembiayaan bersama (co-financing), sepanjang diperlukan.

(3) Rencana Umum Pengadaan Barang/Jasa meliputi kegiatan sebagai berikut:

a. mengidentifikasi kebutuhan Barang/Jasa yang diperlukan K/L/D/I;

b. menyusun dan menetapkan rencana penganggaran untuk Pengadaan Barang/Jasa sebagaimana dimaksud pada ayat (2);

c. menetapkan kebijakan umum tentang:

1) pemaketan pekerjaan;

2) cara pengadaan barang/jasa; dan 
3) pengorganisasian pengadaan barang/ jasa;

d. menyusun Kerangka Acuan Kerja (KAK).

(4) KAK sebagaimana dimaksud pada ayat (3) huruf d paling sedikit memuat:

a. uraian kegiatan yang akan dilaksanakan;

b. waktu pelaksanaan yang diperlukan;

c. spesifikasi teknis barang/jasa yang akan diadakan; dan

d. besarnya total perkiraan biaya pekerjaan.

24. Dalam Pasal 23 dinyatakan:

(1) Penyusunan rencana umum pengadaan barang/jasa pada K/L/D/I untuk tahun anggaran berikutnya atau tahun anggaran yang akan datang, harus diselesaikan pada tahun anggaran yang berjalan.

(2) $\mathrm{K} / \mathrm{L} / \mathrm{D} / \mathrm{I}$ menyediakan biaya untuk pelaksanaan pemilihan penyedia barang/jasa yang dibiayai dari APBN/APBD, yang meliputi:

a. honorarium personil organisasi pengadaan barang/jasa termasuk tim teknis, tim pendukung dan staf proyek;

b. biaya pengumuman pengadaan barang/jasa termasuk biaya pengumuman ulang;

c. biaya penggandaan dokumen pengadaan barang/jasa; dan

d. biaya lainnya yang diperlukan untuk mendukung pelaksanaan Pengadaan Barang/Jasa.

(3) K/L/D/I menyediakan biaya untuk pelaksanaan pemilihan penyedia barang/jasa yang pengadaannya akan dilakukan pada Tahun Anggaran berikutnya.

(4) K/L/D/I dapat mengusulkan besaran Standar Biaya Umum (SBU) terkait honorarium bagi personil organisasi pengadaan, sebagai masukan/pertimbangan dalam penetapan SBU oleh Menteri Keuangan/Kepala Daerah.

25. Dalam Pasal 25 dinyatakan: 
(1) PA mengumumkan rencana umum pengadaan barang/jasa di masing-masing K/L/D/I secara terbuka kepada masyarakat luas setelah rencana kerja dan anggaran $\mathrm{K} / \mathrm{L} / \mathrm{D} / \mathrm{I}$ disetujui oleh DPR/DPRD.

(2) Pengumuman sebagaimana dimaksud pada ayat (1), paling kurang berisi:
a. nama dan alamat pengguna anggaran;
b. paket pekerjaan yang akan dilaksanakan;
c. lokasi pekerjaan; dan
d. perkiraan besaran biaya.

(3) Pengumuman sebagaimana dimaksud pada ayat (2), dilakukan dalam website K/L/D/I masing-masing dan papan pengumuman resmi untuk masyarakat serta Portal Pengadaan Nasional melalui LPSE.

(4) $\mathrm{K} / \mathrm{L} / \mathrm{D} / \mathrm{I}$ dapat mengumumkan rencana pelaksanaan pengadaan barang/jasa yang kontraknya akan dilaksanakan pada tahun anggaran berikutnya/yang akan datang.

26. Dalam Pasal 26 dinyatakan:

(1) Swakelola merupakan kegiatan pengadaan barang/jasa dimana pekerjaannya direncanakan, dikerjakan dan/atau diawasi sendiri oleh $\mathrm{K} / \mathrm{L} / \mathrm{D} / \mathrm{I}$ sebagai penanggung jawab anggaran, instansi pemerintah lain dan/atau kelompok masyarakat.

(2) Pekerjaan yang dapat dilakukan dengan Swakelola meliputi:

a. pekerjaan yang bertujuan untuk meningkatkan kemampuan dan/atau memanfaatkan kemampuan teknis sumber daya manusia serta sesuai dengan tugas pokok $\mathrm{K} / \mathrm{L} / \mathrm{D} / \mathrm{l}$;

b. pekerjaan yang operasi dan pemeliharaannya memerlukan partisipasi langsung masyarakat setempat;

c. pekerjaan yang dilihat dari segi besaran, sifat, lokasi atau pembiayaannya tidak diminati oleh Penyedia Barang/Jasa;

d. pekerjaan yang secara rinci/detail tidak dapat dihitung/ditentukan terlebih dahulu, sehingga apabila dilaksanakan oleh penyedia barang/jasa akan menimbulkan ketidakpastian dan risiko yang besar; 
(3) Prosedur swakelola meliputi kegiatan perencanaan, pelaksanaan, pengawasan, penyerahan, pelaporan dan pertanggungjawaban pekerjaan.

(4) Pengadaan melalui swakelola dapat dilakukan oleh:

a. K/L/D/I penanggung jawab anggaran;

b. Instansi pemerintah lain pelaksana swakelola; dan/atau

c. Kelompok masyarakat pelaksana swakelola.

(5) PA/KPA menetapkan jenis pekerjaan serta pihak yang akan melaksanakan pengadaan barang/jasa secara swakelola.

27. Dalam Pasal 27 dinyatakan:

(1) Pengadaan swakelola oleh K/L/D/I penanggung jawab anggaran:

a. direncanakan, dikerjakan dan diawasi sendiri oleh $\mathrm{K} / \mathrm{L} / \mathrm{D} / \mathrm{I}$ penanggung jawab anggaran; dan

b. mempergunakan pegawai sendiri, pegawai K/L/D/I lain dan/atau dapat menggunakan tenaga ahli.

(2) Jumlah tenaga ahli sebagaimana dimaksud pada ayat (1) huruf b, tidak boleh melebihi 50\% (lima puluh perseratus) dari jumlah keseluruhan pegawai $\mathrm{K} / \mathrm{L} / \mathrm{D} / \mathrm{I}$ yang terlibat dalam kegiatan Swakelola yang bersangkutan.

28. Dalam Pasal 29 dinyatakan pengadaan barang/jasa melalui swakelola oleh $\mathrm{K} / \mathrm{L} / \mathrm{D} / \mathrm{I}$ selaku penanggung jawab anggaran dilaksanakan dengan ketentuan sebagai berikut:

a. pengadaan bahan/barang, Jasa Lainnya, peralatan/suku cadang dan tenaga ahli dilakukan oleh ULP/pejabat pengadaan;

b. pengadaan sebagaimana dimaksud pada huruf a berpedoman pada ketentuan dalam Peraturan Presiden ini;

c. pembayaran upah tenaga kerja yang diperlukan dilakukan secara berkala berdasarkan daftar hadir pekerja atau dengan cara upah borongan;

d. pembayaran gaji tenaga ahli yang diperlukan dilakukan berdasarkan Kontrak;

e. penggunaan tenaga kerja, bahan dan/atau peralatan dicatat setiap hari dalam laporan harian; 
f. pelaksanaan pengadaan barang/jasa yang menggunakan uang persediaan (UP)/uang muka kerja atau istilah lain yang disamakan dilakukan oleh instansi pemerintah pelaksana swakelola;

g. UP/uang muka kerja atau istilah lain yang disamakan, dipertanggungjawabkan secara berkala maksimal secara bulanan;

h. kemajuan fisik dicatat setiap hari dan dievaluasi setiap minggu yang disesuaikan dengan penyerapan dana;

i. kemajuan non fisik atau perangkat lunak dicatat dan dievaluasi setiap bulan yang disesuaikan dengan penyerapan dana; dan

j. pengawasan pekerjaan fisik di lapangan dilakukan oleh pelaksana yang ditunjuk oleh PPK, berdasarkan rencana yang telah ditetapkan.

29. Dalam Pasal 32 dinyatakan:

(1) Pelaksanaan swakelola diawasi oleh penanggung jawab anggaran atau oleh kelompok masyarakat pelaksana swakelola.

(2) Kemajuan pelaksanaan pekerjaan dan penggunaan keuangan dilaporkan oleh pelaksana lapangan/pelaksana swakelola kepada PPK secara berkala.

(3) Laporan kemajuan realisasi fisik dan keuangan dilaporkan setiap bulan secara berjenjang oleh pelaksana swakelola sampai kepada PA/KPA.

(4) APIP pada K/L/D/I penanggung jawab anggaran melakukan audit terhadap pelaksanaan swakelola.

30. Dalam Pasal 35 ayat (2) dinyatakan pemilihan penyedia barang/jasa lainnya dilakukan dengan:

a. Pelelangan yang terdiri atas pelelangan umum dan pelelangan sederhana;

b. Penunjukan langsung;

c. Pengadaan langsung; atau

d. Kontes/sayembara.

31. Dalam Pasal 37 dinyatakan:

(1) Pengadaan pekerjaan yang tidak kompleks dan bernilai paling tinggi Rp 200.000.000,00 (dua ratus juta rupiah) dapat dilakukan dengan:

a. Pelelangan sederhana untuk pengadaan barang/jasa lainnya; atau 
b. Pemilihan langsung untuk pengadaan pekerjaan konstruksi.

(2) Pelelangan sederhana atau pemilihan langsung dilakukan melalui proses pasca kualifikasi.

(3) Pelelangan sederhana atau pemilihan langsung diumumkan sekurangkurangnya di website $\mathrm{K} / \mathrm{L} / \mathrm{D} / \mathrm{I}$, dan papan pengumuman resmi untuk masyarakat serta Portal Pengadaan Nasional melalui LPSE, sehingga masyarakat luas dan dunia usaha yang berminat dan memenuhi kualifikasi dapat mengikutinya.

(4) Dalam pelelangan sederhana atau pemilihan langsung tidak ada negosiasi teknis dan harga. 


\section{BAGIAN VII}

\section{PERSPEKTIF BIAYA TRANSAKSI PADA BASIS PELAYANAN PUBLIK}

\section{A. Konsep Pelayanan Publik}

Pelayanan pada dasarnya dapat didefinisikan sebagai aktivitas seseorang, sekelompok dan/atau organisasi baik langsung maupun tidak langsung untuk memenuhi kebutuhan. Moenir (2003: 16) mengatakan bahwa pelayanan adalah proses pemenuhan kebutuhan melalui aktivitas orang lain secara langsung. Pelayanan merupakan segala bentuk kegiatan pelayanan dalam bentuk barang atau jasa dalam rangka upaya pemenuhan kebutuhan publik.

Pelayanan memberikan persepsi secara konkrit mengenai suatu layanan. Konsep pelayanan ini merupakan suatu revolusi secara menyeluruh, permanen dalam mengubah cara pandang manusia dalam menjalankan atau mengupayakan usahausahanya yang berkaitan dengan proses dinamis, berlangsung, terus menerus di dalam memenuhi harapan, keinginan dan kebutuhan. Hal ini sesuai dengan teori "Quality" yang dikemukakan oleh Marcel, Davidson (2003: 192) bahwa keberhasilan suatu tindakan produk/jasa ditentukan oleh bentuk pelayanan.

Stemvelt, Robert C. (2004: 210) pelayanan adalah suatu persepsi tentang revolusi secara menyeluruh yang terpikirkan dan menjadi suatu gagasan yang harus dirumuskan (formulasi) agar penerapannya (implementasi) dapat diuji kembali (evaluasi), untuk menjadi suatu proses yang dinamis, berlangsung, terus menerus dalam memenuhi kepuasan publik. Teori "tujuan" yang dikembangkan oleh Samuelson, Jeniston (2000: 84) bahwa tujuan adalah asumsi kepuasan yang disesuaikan dengan tingkat pelayanan.

Yong, C.Z., Yun, Y.W., Loh, L. (2003: 146) memberikan suatu pengertian bahwa pelayanan adalah suatu kecocokan untuk penggunaan (fitness for using) yang bertujuan untuk menemukan suatu pemikiran yang jelas dari proses pemikiran yang melahirkan adanya suatu pemahaman yang tidak sulit untuk dipahami, karena elusive goal (tujuannya jelas) dan prosesnya merupakan continue quality improvement (perbaikan yang berkelanjutan).

\section{B. Kesesuaian pelayanan}

Gaspersz, V. (2004: 122) kesesuaian pelayanan menguraikan tentang prinsip pelayanan, akuntabilitas pelayanan, kepemimpinan pelayanan, produktivitas pelayanan, 
responsibilitas pelayanan dan kualitas pelayanan. Unsur-unsur efektivitas pelayanan ini mempunyai tingkat relevansi dalam mewujudkan pemerintahan yang baik.

Padje, dkk. (2006: 2) suatu pelayanan yang sesuai dalam pelayanan pemerintahan, apabila setiap aparat memiliki kemampuan menerapkan rambu-rambu pelayanan yang efektif. Rambu-rambu tersebut harus diterapkan dan dikembangkan oleh setiap aparat pemerintah dalam mewujudkan pemerintahan yang baik. Wujudnya dalam bentuk prinsip pelayanan, akuntabilitas pelayanan, kepemimpinan pelayanan, produktivitas pelayanan, responsibilitas pelayanan dan kualitas pelayanan.

Stemvelt, Robert C. (2004: 57) menyatakan pelayanan yang sesuai diterapkan oleh aparat pemerintah sesuai dengan prinsip layanan, akuntabilitas pelayanan, pengembangan kepemimpinan pelayanan, produktivitas pelayanan yang optimal, responsibilitas pelayanan dan kualitas pelayanan.

Banyak kegiatan pelayanan yang berhasil diaplikasikan oleh berbagai organisasi baik pemerintah maupun swasta, dikarenakan memahami hal-hal yang berkaitan dengan prinsip pelayanan, akuntabilitas pelayanan, kepemimpinan pelayanan, produktivitas pelayanan, responsibilitas pelayanan dan kualitas pelayanan.

Gareth R, Jones (2004: 39) menyatakan the core of service looking from the understand about the principle, accountability, leadership, productivity, responsiveness and quality in services. Inti pelayanan tercermin dari pemahaman mengenai prinsip pelayanan, akuntabilitas pelayanan, kepemimpinan pelayanan, produktivitas pelayanan, responsibilitas pelayanan dan kualitas pelayanan.

Berdasarkan uraian tersebut di atas, perlu dijelaskan pentingnya efektivitas pelayanan dilihat dari unsur-unsur yang menjadi indicator dalam mendukung variabelvariabel dari kesesuaian pelayanan sebagai berikut:

a. Prinsip Pelayanan

Mengembangkan suatu pelayanan diperlukan adanya prinsip yang tepat dalam melayani. Teori "nilai" merupakan landasan dasar dalam mengembangkan suatu pelayanan. Gaspersz, V. (2004: 122) kualitas pelayanan mutu berjalan sesuai dengan prinsip nilai. Prinsip nilai ini yang disebut dengan prinsip pelayanan.

Prinsip pelayanan yang baik adalah memberikan pelayanan yang terbaik kepada publik. wujud pelayanan yang terbaik yaitu terpenuhinya kepuasan 
pelayanan. Rangkuti, Freddy (2004: 59) menyatakan kepuasan pelayanan akan terwujud bila prinsip pelayanan diterapkan dengan baik.

Teori hasil merupakan teori tentang kepuasan pelayanan. Rangkuti, Freddy (2004: 60) hasil pelayanan yang prinsipil adalah kepuasan. Berdasarkan prinsip ini kemudian dalam aplikasi pelayanan pemerintah dirumuskan adanya suatu prinsip pelayanan yang tertuang dalam Keputusan Menteri Negara Pendayagunaan Aparatur Negara Nomor 81 Tahun 1993 tentang Pedoman Tatalaksana Pelayanan Umum yang perlu dipedomani oleh setiap birokrasi publik dalam memberikan pelayanan kepada publik berdasar prinsip pelayanan sebagai berikut:

1) Kesederhanaan, dalam arti bahwa prosedur dan tata cara pelayanan perlu ditetapkan dan dilaksanakan secara mudah, lancar, cepat, tepat, tidak berbelit-belit, mudah dipahami dan mudah dilaksanakan oleh publik yang meminta pelayanan.

2) Kejelasan dan kepastian, dalam arti adanya kejelasan dan kepastian dalam hal prosedur dan tata cara pelayanan, persyaratan pelayanan baik teknis maupun administratif, unit kerja pejabat yang berwenang dan bertanggung jawab dalam memberikan pelayanan, rincian biaya atau tarif pelayanan dan tata cara pembayaran, dan jangka waktu penyelesaian pelayanan.

3) Keamanan, dalam arti adanya proses dan produk hasil pelayanan yang dapat memberikan keamanan, kenyamanan dan kepastian hukum bagi publik

4) Keterbukaan, dalam arti bahwa prosedur dan tata cara pelayanan, persyaratan, unit kerja pejabat penanggung jawab pemberi pelayanan, waktu penyelesaian, rincian biaya atau tarif serta hal-hal lain yang berkaitan dengan proses pelayanan wajib diinformasikan secara terbuka agar mudah diketahui dan dipahami oleh publik, baik diminta maupun tidak diminta.

5) Efesiensi, dalam arti bahwa persyaratan pelayanan hanya dibatasi pada hal-hal yang berkaitan langsung dengan pencapaian sasaran pelayanan dengan tetap memperhatikan keterpaduan antara persyaratan dengan produk pelayanan. 
6) Ekonomis, dalam arti bahwa pengenaan biaya atau tarif pelayanan harus ditetapkan secara wajar dengan memperhatikan: nilai barang/jasa pelayanan, kemampuan publik untuk membayar, dan ketentuan perundang-undangan yang berlaku

7) Keadilan dan Pemerataan, yang dimaksudkan agar jangkauan pelayanan diusahakan seluas mungkin dengan distribusi yang merata dan adil bagi seluruh lapisan publik

8) Ketepatan Waktu, dalam arti bahwa pelaksanaan pelayanan harus dapat diselesaikan tepat pada waktu yang telah ditentukan.

Prinsip pelayanan merupakan seperangkat program yang menjadi kebijakan bagi pemerintah di dalam memberikan pelayanan umum kepada publik, agar formulasi, implementasi dan evaluasi segala bentuk kebijakan sampai ke tujuan yaitu pada publik. Landasan utama dari kebijakan ini adalah Keputusan Menteri No. 81 Tahun 2003 tentang Pedoman Pelayanan Umum yang Diterapkan pada Instansi Pemerintah.

Pada dasarnya, pedoman tersebut adalah pedoman prinsip pelayanan yang memiliki unsur-unsur pelayanan yang bersifat sederhana, tepat waktu, terbuka, adil yang merata, efisien dan ekonomis dalam pemberian pelayanan kepada publik luas di dalam mendapatkan pelayanan, sehingga kontribusi terhadap pelayanan tersebut tidak memberatkan publik untuk membayar biaya-biaya yang dikenakan, karena telah diatur berdasarkan UU yang berlaku. Yoga (2003: 48) setiap bentuk kegiatan prinsip pelayanan adalah memberikan pelayanan yang berkualitas sesuai dengan unsur-unsur pelayanan yang sederhana, tepat waktu, terbuka, adil yang merata, efisien dan ekonomis, yang menjadi tuntutan dari setiap publik yang dilayani, dengan sendirinya akan memberikan suatu kontribusi dalam pembiayaan yang dikenakan, sesuai dengan ketentuan yang berlaku.

Pengertian ini mengisyaratkan bahwa setiap kegiatan prinsip pelayanan, publik menghendaki adanya unsur-unsur pelayanan yang sederhana, tepat waktu, terbuka, adil dan merata, efisien dan ekonomis, sehingga pelayanan ini menjamin publik puas dan memberikan kontribusi yang positif atas kegiatan pelayanan yang diterimanya.

Prinsip pelayanan merupakan bentuk dari suatu kebijakan pelayanan yang harus diberikan kepada publik, karena konsep pelayanan merupakan 
konsensus dari pemerintah sebagai pelayan publik untuk menempatkan pelayanan sebagai suatu kegiatan kerja yang berada di atas segala-galanya, sehingga penilaian suatu organisasi terhadap kegiatan yang dilakukan oleh aparatur adalah menjalankan pelayanan seoptimal mungkin.

Kesederhanaan dalam pelayanan sangat diperlukan, karena setiap kegiatan pelayanan yang sederhana itu dioperasionalkan secara mudah, teratur, tertib dan terpadu. Kesederhanaan dapat diartikan dalam tiga hal yaitu sederhana dalam bentuk, sederhana dalam sifat dan sederhana dalam proses. Bentuk-bentuk kesederhanaan ini tentunya berbeda-beda dari masing-masing organisasi dalam memberikan kegiatan pelayanan yang sederhana.

Pelayanan sederhana juga diartikan sederhana dalam operasionalnya, sederhana dalam prosedurnya dan sederhana dalam manajerialnya. Bagi publik sangat menghendaki adanya pelayanan yang tidak berbelit-belit, mudah digunakan dan mudah diperoleh. Ashilah, Zahrani (2003: 49) kesederhanaan adalah kegiatan pelayanan secara bentuk, sifat dan proses sederhana dilakukan, tidak menyusahkan dan tidak memberatkan, sehingga kegiatan operasionalnya dalam suatu organisasi akan mudah diterapkan secara operasional, manajerial dan secara teknis, yang sering diungkapkan bahwa kegiatan pelayanan yang sederhana yaitu kegiatan yang tidak terlalu kontras dan berbelit-belit.

Kesederhanaan dalam tinjauan prinsip pelayanan dapat diwujudkan apabila dalam suatu organisasi dalam memberikan kegiatan pelayanan, pihak yang dilayani tidak merasakan adanya suatu beban atau merasakan adanya suatu kendala yang menyusahkan, yang dapat menimbulkan adanya kritikan atau keluhan.

Syarat pelayanan sederhana yaitu tidak terlalu kontras dan berbelitbelit. Kontras yang diartikan tidak menunjukkan suatu kegiatan pelayanan yang sengaja dipersulit atau menyebabkan pihak yang dilayani merasa tidak tertarik untuk mendapatkan pelayanan. Sedangkan yang berbelit-belit adalah suatu kegiatan pelayanan yang terlalu direkayasa atau diada-adakan. Diantara prinsip pelayanan, unsur pelayanan kesederhanaan diperlukan oleh publik karena dengan pelayanan yang sederhana, publik dapat merasakan bahwa pihak yang melayani mengerti bahwa publik tidak menyenangi adanya bentuk pelayanan yang berbelit-belit, antri dan prosedur yang panjang dan lama. 
Suatu organisasi yang bergelut dalam bidang pelayanan, pertimbangan terhadap pemanfaatan dan penggunaan waktu menjadi suatu hal yang sangat penting untuk dipertimbangkan. Penggunaan waktu pelayanan yang tidak tepat menjadi penyebab pihak yang dilayani selalu mengeluh dan mengkritik adanya hal-hal yang dapat merugikan pihak yang dilayani.

Sesungguhnya waktu sangat berharga dan penting bagi pihak yang membutuhkan waktu untuk menjalankan segala bentuk kegiatan pelayanan lainnya. Karena itu, dalam konsep manajemen modern termasuk manajemen organisasi berupaya mengembangkan suatu kebijakan keputusan pelayanan yang tepat waktu (on time). Ketepatan waktu dalam suatu kegiatan pelayanan menjadi penting dan menjadi unsur yang dipertimbangkan dalam menentukan prinsip pelayanan.

Unsur prinsip pelayanan adalah tepat waktu. Bahwasahnya setiap publik yang ingin dilayani senantiasa memperhatikan adanya waktu pelayanan yang betul-betul sesuai dengan kepastian layanan, komitmen terhadap waktu pelayanan dan adanya penyelesaian pelayanan yang singkat.

Pelayanan tepat waktu adalah pelayanan yang menfokuskan kepada penggunaan waktu yang tepat sesuai dengan keinginan dan harapan publik yang dilayani. Setiap publik menghendaki pemberian pelayanannya memiliki kepastian waktu yang jelas, sesuai dengan komitmen tepat waktu dalam pelayanan, dan senantiasa memperhatikan azas pelayanan yang cepat atau singkat.

Guricci, Guntur (2002) pelayanan tepat waktu dalam manajemen organisasi dan dalam berbagai bentuk kepentingan pelayanan, menjadi suatu pertimbangan yang sangat penting. Pihak yang memberikan pelayanan yang tidak sering tepat waktu menyebabkan tidak terpenuhinya keinginan dan harapan publik yang dilayani.

Pelayanan yang sering mengalami penundaan atau senantiasa tidak tepat waktu akan memberikan imej yang tidak konsisten dengan kepastian waktu yang jelas, sehingga terkadang banyak komitmen yang telah dibuat dalam suatu pelayanan cenderung terabaikan, bahkan terkadang tidak terjadi, karena itu suatu kegiatan pelayanan tidak dapat dipisahkan dari adanya asas pelayanan yang cepat atau singkat dalam rangka mewujudkan suatu pelayanan yang sesuai dengan tingkat kebutuhan dan volume waktu yang diperlukan dalam kegiatan pelayanan. 
Suatu organisasi yang memahami pentingnya kemajuan dan kepercayaan suatu organisasi dari publik, senantiasa memperhatikan standar pelayanan yang tepat waktu, agar setiap kegiatan pelayanan yang dilakukan dapat terwujud sesuai dengan waktu yang ditetapkan.

Pelayanan yang tepat waktu dilakukan untuk menghindari adanya pelayanan yang tidak konsisten dalam kegiatan pelayanan, menggunakan waktu pelayanan yang tidak efisien dan menghindari adanya suatu pelayanan yang terlalu monoton, sehingga suatu pelayanan harus dijalankan sesuai dengan waktu yang tepat, karenanya pelayanan yang tepat waktu harus dapat dijadwalkan sesuai dengan penggunaan waktu dan kebutuhan volume orang yang dilayani.

Nurdin, Djalil (2003: 75) prinsip pelayanan ketepatan waktu adalah memberikan suatu pelayanan yang sesuai dengan jadwal kegiatan pelayanan dan kebutuhan waktu pelayanan, agar waktu yang digunakan dapat terukur sesuai dengan tujuan yang ingin dicapai.

Pemahaman prinsip pelayanan ketepatan waktu, merupakan suatu penilaian bahwa suatu kegiatan pelayanan yang telah terorganisir dalam suatu kegiatan organisasi tidak dapat dipisahkan dari adanya kegiatan penggunaan waktu yang sesuai dengan rencana yang telah dijadwalkan, rencana yang akan dilaksanakan dan pengukuran waktu pelayanan yang sesuai dengan pelaporan, sehingga evaluasi terhadap prinsip pelayanan yang tepat waktu dapat dinilai untuk dapat mengembangkan dan memajukan kegiatan-kegiatan pelayanan saat ini dan di masa akan datang.

Selain itu suatu organisasi menyadari bahwa dalam memberikan suatu pelayanan kepada publik, dituntut untuk memberikan pelayanan yang transparan. Pelayanan transparan yang dimaksud adalah pelayanan yang sifatnya terbuka atau tingkat keterbukaannya menjadi ciri khas dalam memberikan kegiatan pelayanan, sehingga setiap pelayanan yang diberikan dijalankan sesuai ketentuan prosedur dan mekanisme yang diterapkan, dan keterbukaan tersebut merupakan ciri khas dari suatu kebijakan yang diterapkan oleh suatu organisasi.

Keterbukaan dalam standar pelayanan prima menjadi hal yang penting dan perlu dalam menjalankan imej kegiatan pelayanan yang telah menjadi suatu pedoman sesuai dengan prinsip pelayanan yang menjadi pedoman bagi suatu organisasi pemerintah. 
Prinsip pelayanan berupa pelayanan yang bersifat terbuka atau transparan. Setiap publik menghendaki adanya suatu pelayanan yang bersifat terbuka, sehingga publik memahami bahwa pelayanan tersebut demikian adanya. Keterbukaan pelayanan tersebut berupa keterbukaan atas berbagai informasi dan keterangan-keterangan yang penting tentang pelayanan seperti keterbukaan informasi, prosedur, biaya dan waktu penyelesaian, sehingga publik tidak perlu mengkritik dan mengeluh atas pelayanan yang didapatkannya.

Rizal, Syamsurya (2004: 13) menyatakan bahwa publik dalam mendapatkan pelayanan senantiasa menerapkan adanya pelayanan yang terbuka dalam berbagai informasi, prosedur, biaya dan waktu penyelesaian, sehingga memahami bentuk pelayanan yang diterimanya yang tidak menimbulkan adanya kecurigaan atas segala bentuk kegiatan-kegiatan pelayanan yang pada akhirnya menimbulkan adanya kritikan dan keluhan.

Kemajuan suatu kegiatan pelayanan banyak ditentukan oleh tanggapan publik tentang pelayanan yang dirasakannya. Suatu hal yang sangat dikritik atau dibenci oleh publik adalah pelayanan yang tidak terbuka atau transparan di dalam kegiatan pelayanannya, sehingga terkadang terjadi berbagai diskomunikasi atau terjadi kesalahpahaman atas bentuk-bentuk standar pelayanan yang diterima, karena pihak pemberi pelayanan tidak terbuka dalam memberikan informasi, tidak terbuka dalam memberikan bentuk pelayanan yang sesuai dengan biaya dan waktu penyelesaiannya, sehingga terkadang bahwa suatu kegiatan yang sifatnya tidak terbuka menimbulkan adanya berbagai interpretasi dari publik terhadap kegiatan pelayanan yang dilakukan oleh suatu organisasi.

Organisasi dalam melaksanakan kegiatan pelayanan kepada publik, menyadari bahwa pemberian pelayanan harus diperoleh, diterima dan dinikmati oleh seluruh lapisan publik. Pelayanan harus merata sesuai dengan keadilan yang diterima oleh publik atau dengan kata lain, setiap kegiatan pelayanan harus memiliki prinsip adil yang merata. Hal ini untuk menghindari adanya pemahaman bahwa pelayanan bersifat diskriminatif.

Pada umumnya, setiap pelayanan menghendaki adanya pelayanan adil yang merata, karena suatu pelayanan yang dilakukan harus bersifat umum, tidak diskriminatif dan mempunyai tujuan yang sama, sehingga pelayanan yang didapatkan oleh setiap publik dirasakan adil dan merata untuk semua 
kalangan. Ilham, Thamrin (2005: 147) pelayanan yang tidak diskriminatif adalah kriteria dari suatu pelayanan bersifat umum, tidak diskriminatif dan mempunyai tujuan yang sama bagi setiap publik yang dilayani. Karena pelayanan ini tidak menghendaki adanya hal-hal yang membedakan antara satu pelayanan kepada orang yang dilayani berbeda dengan pelayanan yang diterima oleh pihak lain.

Pelayanan yang tidak mendiskriminatif merupakan suatu wujud pelayanan untuk publik atau pelayanan untuk publik, sehingga setiap warga negara berhak untuk menerima perlakuan pelayanan yang sama tanpa memandang bulu berdasarkan ras, agama atau etnis, sehingga dapat dikatakan bahwa pelayanan adil yang merata adalah pelayanan yang tidak diskriminatif, atau pelayanan yang bersifat umum yang tidak membedakan berdasarkan status, kondisi ekonomi dan hal-hal lainnya yang membedakan antara individu publik yang satu dengan publik yang lain.

Natsir, Muh. (2004: 76) pelayanan adil yang merata adalah pelayanan yang menyenangkan dan memberikan adanya keadilan yang sesuai dengan kebutuhan bagi setiap publik yang membutuhkan pelayanan sesuai dengan tingkat kontribusi dan prioritas yang diterimanya. Pelayanan yang tidak diskriminatif adalah pelayanan yang dilakukan secara adil dan merata kepada setiap warga publik dalam menerima pelayanan adil sesuai kebutuhan kontribusi dan prioritas pelayanan, sehingga pelayanan tersebut bersifat adil dan diperuntukkan pada semua publik yang membutuhkan pelayanan sesuai dengan prioritas dan kontribusi pelayanan yang diinginkannya.

Umumnya pelayanan yang efisien adalah salah satu syarat yang harus dipenuhi oleh prinsip pelayanan dalam memberikan pelayanan kepada pihak yang dilayani. Pengertian efisiensi dari suatu pelayanan adalah bagaimana manfaat dari kegiatan pelayanan yang diberikan dirasakan sangat sesuai dengan manfaat dan keuntungan yang diterimanya, dan manfaat tersebut sangat tepat dengan moment atau waktu kegiatan pelayanan yang diberikan.

Banyak bentuk-bentuk kegiatan pelayanan dirasakan oleh pihak yang menerima pelayanan tidak efisien, karena manfaat dan kegunaannya tidak sesuai dengan moment waktu pelayanan yang dibutuhkannya. Setiap pelayanan yang menjadi prinsip pelayanan, berusaha untuk memberikan pelayanan kepada publik secara efisien berdasarkan manfaat dan kegunaan di dalam melakukan serangkaian kegiatan pelayanan. 
Dalam pandangan Zulkifli, Anwar (2002: 16) bahwa suatu pelayanan membutuhkan adanya sifat efisien, agar setiap bentuk pelayanan yang dilakukan dapat diperhitungkan segi manfaat dan kegunaannya, sehingga pelayanan tersebut tidak sia-sia atau menjadi suatu pelayanan yang tidak konstruktif di dalam memperoleh kesesuaian pelayanan yang diterima.

Tentunya pendapat tersebut di atas memberikan suatu signal yang kuat di dalam memahami suatu efisiensi pelayanan. Kegiatan pelayanan harus memiliki suatu nilai tambah atau nilai utama dari kegiatan pelayanan yang dilakukan, khususnya nilai manfaat dan nilai guna sehingga kegiatan pelayanan yang dilakukan tidak memberikan bias negatif atau dengan kata lain tidak memberikan adanya nilai kesia-siaan dari bentuk kegiatan pelayanan yang dilakukan. Suatu kegiatan pelayanan yang efisien harus menunjukkan adanya nilai manfaat dan nilai guna yang menjadi suatu momen yang penting dan berharga dalam setiap kegiatan pelayanan.

Pendapat tersebut seyogianya telah mendasari pihak aparat untuk mempertimbangkan dan memperhatikan bahwa suatu kegiatan pelayanan harus efisien. Artinya bagi pihak aparat dan warga publik yang membutuhkan pelayanan merasakan bahwa kegiatan pelayanan yang dilakukannya betulbetul efisien sesuai dengan kegunaan dan manfaatnya, sehingga tujuan dari suatu organisasi yang memberikan pelayanan tepat.

Kegiatan pelayanan dalam suatu organisasi, tidak terlepas dari adanya kegiatan yang bersifat pengeluaran biaya atau anggaran, sehingga kegiatan pelayanan seyogyanya harus diupayakan secara sadar dan terencana, agar kegiatan yang dilakukan menghasilkan (output) yang maksimal dengan meminimalkan korbanan, sehingga aspek ekonomis kegiatan pelayanan dapat dilakukan. Aspek kegiatan ekonomis pelayanan merupakan interpretasi bahwa dalam melaksanakan kegiatan pelayanan harus dipandang sebagai suatu kegiatan yang tidak merugikan pihak organisasi dan tidak merugikan publik. Demikian halnya suatu kegiatan pelayanan tidak terlepas dari adanya penggunaan biaya. Penggunaan biaya adalah sesuatu yang tidak dapat dihindari, namun suatu pelayanan harus bersifat ekonomis.

Oleh karena itu bahwa pelayanan yang ekonomis dimaksudkan agar setiap kegiatan dapat dilakukan berdasarkan pengukuran besarnya alokasi biaya dan penggunaan biaya yang tepat sasaran, sehingga tidak terjadi adanya 
penyimpangan biaya yang membengkak, dapat merugikan kegiatan pelayanan tersebut.

Boeyong, Soetanto (2001: 28) menyatakan pelayanan ekonomis adalah pelayanan yang berasas penghematan dan pelayanan yang terukur penggunaan biayanya, sehingga bentuk-bentuk pembiayaan yang dikenakan dalam pelayanan harus dapat terjangkau dan tidak memberatkan pihak yang menerima pelayanan.

Disadari oleh suatu organisasi bahwa dalam kegiatan pelayanan dibutuhkan adanya suatu proses. Proses ini harus memiliki azas penghematan dan azas pelayanan penggunaan biaya yang berimbang, sehingga bentukbentuk pembiayaan yang dilakukan dalam suatu organisasi atas kegiatan pelayanan betul-betul sesuai dengan manfaatnya.

Pelayanan ekonomis berarti pelayanan yang dilakukan sesuai dengan penggunaan alokasi anggaran dan penggunaannya sesuai dengan manfaat yang diperoleh. Biaya anggaran yang dikeluarkan dari kegiatan pelayanan harus dapat terjangkau oleh seluruh lapisan publik dalam hal ini pihak yang menerima kegiatan pelayanan, dan kegiatan tersebut tidak memberatkan pihak yang menerima pelayanan, sehingga penilaian terhadap kegiatan pelayanan menjadi unsur yang tidak memberatkan bagi publik.

Berdasarkan uraian tersebut di atas, prinsip pelayanan penting untuk diefektifkan dalam mewujudkan pemerintahan yang baik, dalam rangka membumikan kualitas suatu pelayanan yang prinsipil dipahami oleh aparat dalam menjamin pelaksanaan pelayanan publik.

b. Akuntabilitas Pelayanan

Konsep dan keterkaitan pelayanan publik yang baik membutuhkan adanya model akuntabilitas pelayanan. Secara teoritis akuntabilitas dalam beberapa model atau tipe dapat dibedakan dalam empat model. Osborne, David Plastrik and Peter (1997: 44) membedakan akuntabilitas dalam empat model yaitu regularity accountability, managerial accountability, program accountability, dan process accountability.

Rakhmat (2009: 45) akuntabilitas administrasi merupakan suatu akuntabilitas yang memerlukan adanya hubungan hirarki yang jelas diantara pusat-pusat pertanggungjawaban dengan unit-unit dibawahnya. Hubungan hirarki ini biasanya telah ditetapkan dengan jelas baik dalam bentuk aturan 
organisasi yang disampaikan secara formal ataupun dalam bentuk jaringan hubungan informal, yang konkritnya dalam bentuk pelayanan publik yang accountability.

Konsep akuntabilitas dalam administrasi publik menurut Osborne, David Plastrik and Peter (1997: 45) mencakup empat mekanisme yaitu akuntabilitas birokrasi, hukum, profesional dan politik. Faktor penting yang membentuk mekanisme akuntabilitas publik adalah tergantung pada bagaimana kemampuan mendefinisikan dan mengendalikan harapan-harapan yang dilakukan oleh keseluruhan lembaga di dalam atau diluar organisasi. Untuk itu akuntabilitas administrasi publik sesungguhnya berkaitan dengan bagaimana birokrasi publik mewujudkan harapan-harapan dalam pelayanan publik.

Rakhmat (2009: 50) akuntabilitas pelayanan publik profesional terjadi ketika pemerintah mengkaji terus masalah kompleks dan kesulitan teknis pelayanan. Dalam kondisi tersebut harus diarahkan pada keahlian dan keterampilan bawahan untuk memberikan solusi yang tepat.

Jabra dan Dwivedi (1989: 149) menyatakan bahwa akuntabilitas pelayanan berbeda karena kriteria yang digunakan untuk menentukan akuntabilitas pelayanan yang profesional yang dipengaruhi oleh norma dan etika profesi yang disetujui dan diterapkan di setiap profesi.

Salah satu langkah penting untuk mengimplementasikan akuntabilitas secara efektif adalah mendorong munculnya suatu kebijakan dan manajemen program yang jelas (Rakhmat, 2009).

Akuntabilitas Pelayanan publik merupakan satu kegiatan pelayanan yang dilakukan oleh instansi untuk mencapai tujuan tertentu, yang dilakukan oleh instansi yang berkewenangan dalam rangka penyelenggaraan tugas pemerintahan dan pembangunan. Dalam konteks penyelenggaraan pelayanan pemerintahan, khususnya pemerintahan daerah, suatu kebijakan pada hakikatnya bersifat kompleks dan berkaitan dengan banyak aspek kehidupan untuk memecahkan masalah pemerintahan dan kepublikan.

Teori "hirarki" dikemukakan oleh Zulkifli, Anwar (2002: 101) bahwa suatu akuntabilitas pelayanan secara hirarki meliputi standar pelayanan, tindakan pelayanan dan pelaksanaan tugas pokok dan fungsi pelayanan. Hierarki ini penting dalam mewujudkan kepuasan pelayanan publik. 
Mengembangkan suatu akuntabilitas pelayanan publik memerlukan standar pelayanan. Gaspersz, V. (2004: 94) kunci dari suatu akuntabilitas pelayanan adalah standar mutu pelayanan. Standar mutu pelayanan ini merupakan bentuk pelayanan keberpihakan kepada publik.

Akuntabilitas pelayanan publik merupakan tindakan untuk memenuhi keinginan, perintah, harapan dan kebutuhan dari orang yang dilayani sesuai dengan tindakan pelayanan yang diberikan. Teori "tindakan" yang dikemukakan oleh Gaspersz, V. (2004: 139) menyatakan bahwa suatu keberhasilan akuntabilitas pelayanan ditentukan oleh tindakan pelayanan yang konsisten dan terpercaya.

Wujud dari suatu akuntabilitas pelayanan adalah berjalannya pelayanan sesuai mekanisme dan kode etik yang memberikan penguatan pelayanan dengan baik. Norman, Davis (2004: 81) menyatakan get service to public with doing of main task and function suitable with public desire. Berilah pelayanan kepada publik dengan menjalankan tugas pokok dan fungsi sesuai dengan keinginan publik.

Akuntabilitas dalam penyelenggaraan pelayanan publik adalah suatu ukuran yang menunjukkan beberapa besar tingkat kesesuaian penyelenggaraan pelayanan dengan ukuran nilai-nilai atau norma eksternal yang ada di publik atau yang dimiliki oleh para stakeholders. Nilai dan norma pelayanan yang berkembang dalam publik tersebut di antaranya meliputi transparansi pelayanan, prinsip keadilan, jaminan penegakan hukum, hak asasi manusia, dan orientasi pelayanan yang dikembangkan terhadap publik pengguna jasa.

Akuntabilitas penyelenggaraan pelayanan publik meliputi: (1) acuan pelayanan yang dipergunakan aparat birokrasi dalam proses penyelenggaraan pelayanan publik. (2) tindakan yang dilakukan oleh aparat dalam memenuhi syarat pelayanan yang telah ditentukan; dan (3) menjalankan tugas pelayanan sesuai prioritas.

Aparat birokrasi dalam memberikan akuntabilitas pelayanan publik seringkali masih menerapkan standar nilai atau norma pelayanan secara sepihak, seperti pemberian pelayanan yang hanya berdasarkan pada juklak (petunjuk dan pelaksanaan) sehingga kecenderungan yang terjadi melemahnya komitmen aparat birokrasi untuk akuntabel terhadap publik yang dilayaninya. 
Salah satu faktor penyebab yang menjadikan rendahnya tingkat akuntabilitas pelayanan adalah terlalu lamanya proses indoktrinasi kultur birokrasi yang mengarahkan aparat birokrasi untuk selalu melihat ke atas. Selama ini aparat birokrasi telah terbiasa lebih mementingkan kepentingan pimpinan daripada kepentingan publik pengguna jasa. Birokrasi tidak pernah merasa bertanggung jawab kepada publik, melainkan bertanggung jawab kepada pimpinan atau atasannya.

Dalam pandangan para pakar mayoritas menjelaskan bahwa akuntabilitas pelayanan publik masih tetap menjadi isu yang penting bagi upaya ke arah perbaikan kinerja birokrasi pemerintah. Tindakan untuk melakukan reformasi birokrasi terutama diarahkan pada upaya untuk peningkatan efisiensi, transparansi dan akuntabilitas birokrasi (Ashilah, Zahrani, 2003). Akuntabilitas pelayanan publik memberikan implikasi pada meningkatnya tingkat korupsi di dalam birokrasi, tetapi reformasi tetap dilakukan di semua tingkatan birokrasi. Apabila reformasi dilakukan pada tingkat birokrasi pusat saja, hal tersebut justru hanya akan memindahkan korupsi dan birokrasi pusat ke birokrasi yang ada di daerah. Acuan pelayanan yang digunakan oleh aparat birokrasi juga dapat menunjukkan tingkat akuntabilitas pemberian pelayanan publik.

Dalam kaitan ini bahwa acuan pelayanan yang dianggap paling penting dalam merefleksikan pola pelayanan yang digunakan untuk mencapai tujuan organisasi adalah pola pelayanan yang akuntabel. Pola pelayanan yang mengacu pada kepuasan publik sebagai pengguna jasa. Akuntabilitas pelayanan publik mempengaruhi suatu pola pelayanan yang diterapkan oleh organisasi pemerintah.

Uraian-uraian di atas memberikan suatu gambaran bahwa akuntabilitas pelayanan diperlukan untuk memberikan pelayanan yang terbaik kepada publik. Inti dari akuntabilitas pelayanan publik adalah implementasinya sebagai acuan pelayanan, tindakan dan pelaksanaan pelayanan.

c. Masalah Kepemimpinan

Suatu organisasi yang berhasil di dalam mengembangkan dan memajukan organisasinya, selalu bertumpu pada pelayanan. Inti dari suatu pelayanan sangat ditentukan oleh kepemimpinan organisasi. kepemimpinan organisasi ini disepadankan dengan kepemimpinan pelayanan. Kepemimpinan organisasi yang berhasil dalam mengantar pencapaian tujuan organisasi, tentu 
ditentukan oleh kemampuan seorang pemimpin dalam mengarahkan bawahannya atau aparat untuk memberikan pelayanan terbaik kepada publik.

Rivai, Veithzal (2005: 64) menyatakan kepemimpinan merupakan alat pelaksana utama dari kegiatan manajemen yang bertumpu kepada kegiatan pelayanan. Siagian, P. Sondang (2004: 25) konsep kepemimpinan melahirkan kemampuan organisasi dalam mengelola manajemen berbasis pelayanan. Penerapan pelayanan yang berbasis manajemen sesuai dengan kepemimpinan pelayanan. Wujud kepemimpinan pelayanan publik yaitu mendengarkan, empati, menyembuhkan, kesadaran, bujukan atau persuasif, konseptualisasi, kemampuan meramalkan, kemampuan melayani, komitmen terhadap pertumbuhan manusia, dan membangun publik.

Mengembangkan suatu kepemimpinan pelayanan, seorang pemimpin organisasi selalu berupaya untuk menganjurkan dan memberikan konsep tentang pelayanan yang baik melalui suatu proses kemampuan aparat untuk mendengarkan semua keluhan publik. Teori "kuping" yang diperkenalkan oleh Smoothz dalam Anshory, Amir (2005: 29) menyatakan pelayanan yang baik adalah memasang kuping untuk mendengarkan keluhan publik.

Hal ini berarti aparat dalam mengembangkan tugas pokok dan fungsinya dalam pelayanan kepada publik, selalu peka untuk mendengarkan segala keluhan, kritikan dan ketidakpuasan dari bentuk pelayanan yang diterima. Melalui proses mendengarkan dengan baik diketahui berbagai aspek yang perlu ditingkatkan atau solusi dalam memberikan pelayanan yang terbaik sebagai wujud dari kepemimpinan pelayanan dalam mendengarkan.

Kemampuan mengembangkan pelayanan publik yang dimiliki oleh kepemimpinan organisasi atau kepemimpinan pelayanan harus ditunjang oleh adanya empati berwujud kemampupahaman mengetahui, merasakan dan mengembangkan aspek penilaian tentang pelayanan yang diberikan kepada publik. Teori "iba" yang diperkenalkan oleh Norman, Davis (2004: 91) menyatakan tingkatkan kualitas pelayanan dengan mengiba kepada publik untuk mendapatkan empati pelayanan.

Artinya, dalam suatu kegiatan pelayanan, setiap aktor pelayan harus mengiba untuk mendapatkan perhatian publik dalam rangka mengembangkan kemampupahaman untuk memberikan pelayanan yang terbaik. 
Suatu pelayanan publik yang kurang kuratif akan menimbulkan suatu epidemik respon pelayanan yang kurang baik. Ini harus jeli dilihat oleh kemampuan kepemimpinan manajemen dalam memberikan pelayanan yang terbaik. Banyaknya penyakit kronis pelayanan yang tidak terdiagnosis menimbulkan kesenjangan yang berkepanjangan. Hal ini menjadi pertimbangan bagi aparat untuk melakukan suatu "treatment" yang sifatnya menyembuhkan dari berbagai indikasi pelayanan yang tidak memuaskan.

Teori perlakuan merupakan suatu teori penyembuhan di dalam mengembangkan pelayanan yang mampu mengembangkan eksistensi pelayanan sebagai aspek yang dapat menyembuhkan aktivitas pelayanan yang tidak sesuai dengan kenyataan riil. Teori perlakuan yang dimaksud yaitu sembuhkan segala bentuk penyakit pelayanan yang tidak sesuai dengan mekanisme dan prosedur yang berlaku (Norman, Davis, 2004: 190).

Mengembangkan suatu aktivitas pelayanan dalam kepemimpinan, dituntut adanya seorang pemimpin yang mampu memberikan kesadaran tentang pentingnya pelayanan. Kesadaran adalah hasil dari suatu pemahaman yang mendalam tentang arti pelayanan yang dipahaminya.

Kesadaran dalam kepemimpinan pelayanan merupakan inti yang membentuk karakter seorang pemimpin pelayanan mampu memberikan pelayanan yang terbaik. Kesadaran menjadikan suatu pelayanan akan bersifat persuasif.

Pengertian persuasif dalam kepemimpinan pelayanan adalah kemampuan dari aparat yang dipimpin untuk memberikan pelayanan dengan cara yang sopan melalui kemampuan persuasif yaitu membujuk publik untuk dapat memahami dan mengembangkan prosedur atau mekanisme pelayanan yang tepat dalam rangka mewujudkan pelayanan yang sederhana, tepat waktu, mudah dan ekonomis.

Konsep kepemimpinan pelayanan persuasif dapat menggunakan konsep pendekatan hati. Konsep ini menjelaskan bagaimana suatu kegiatan pelayanan dilakukan dengan penuh ketulusan, melakukan pelayanan sebagai panggilan tugas dan kewajiban yang harus diemban untuk mencapai tujuan dari suatu pelayanan.

Suatu pelayanan yang diterapkan dalam bentuk kepemimpinan pelayanan harus sesuai dengan konsep pelayanan yang sistematik, konsisten, 
logis, dan kompleks dalam menghasilkan wujud pelayanan yang baik. Konsep pelayanan kontekstual yang digunakan yaitu pelayanan adalah aturan yang tertulis sebagai kode etik untuk menghasilkan keteraturan pelayanan (Norman, Davis, 2004: 122).

Memberikan pelayanan sesuai dengan aksesibilitas kepemimpinan pelayanan yang didasarkan oleh adanya konsep kemampuan meramalkan suatu tindakan pelayanan yang tepat sasaran. Konsep prediksi atau estimasi menyatakan lakukan pelayanan sesuai dengan prediksi penyelesaian dan terpenuhinya kepuasan.

Prediksi merupakan wujud nyata dari suatu tindakan peramalan yang sesuai dengan kemampuan aksesibilitas dalam menghasilkan pencapaian sasaran yang tepat, terpadu dan sesuai dengan kapabilitas pencapaian tujuan kepemimpinan pelayanan. Tuntutan kepemimpinan pelayanan menghendaki adanya suatu kemampuan melayani sesuai dengan target yang telah direalisasikannya.

Mengembangkan suatu pelayanan yang sesuai dengan kemampuan melayani tentu dilakukan oleh aparat pelayanan yang memiliki komitmen yang tinggi terhadap pertumbuhan pelayanan sesuai dengan dinamika tuntutan kebutuhan manusia. Teori "alami" dari Anshari, Haninpraja (2003: 7) menyatakan manusia sebagai makhluk sosial saling tolong menolong untuk mencapai tujuannya.

Berdasarkan pertimbangan tersebut, suatu kegiatan pelayanan dalam eksistensi kepemimpinan, akan menghasilkan suatu kegiatan proses tindakan dan perilaku secara sadar dalam menghasilkan suatu hasil pelayanan yang disebut dengan pembangunan publik. Pembangunan publik adalah pembangunan pelayanan yang terkoordinir dalam kepemimpinan pelayanan yang senantiasa mendengarkan, empati, menyembuhkan, kesadaran, bujukan atau persuasif, konseptualisasi, kemampuan meramalkan, kemampuan melayani, komitmen terhadap pertumbuhan manusia, dan membangun publik

Kepemimpinan pelayan membahas realitas kekuasaan dalam kehidupan sehari-hari, yang meliputi legitimasi, ketentuan etika dan hasil yang menguntungkan yang dapat dicapai melalui penggunaan kekuasaan yang semestinya. Spears, Larry (2004: 51) mengidentifikasi sepuluh ciri khas pemimpin pelayan, yakni mendengarkan, empati, menyembuhkan, kesadaran, bujukan atau persuasif, konseptualisasi, kemampuan meramalkan, 
kemampuan melayani, komitmen terhadap pertumbuhan manusia, membangun publik.

Kepemimpinan pelayan seperti yang dikemukakan di atas dapat bermakna terhadap publik pelanggannya apabila aparatur pelayan (pemerintah) sungguh-sungguh memperhatikan beberapa dimensi atau atribut perbaikan kualitas jasa termasuk kualitas pelayanan, yang terdiri ketepatan waktu pelayanan, akurasi pelayanan, kesopanan, keramahan dalam memberikan pelayanan, tanggung jawab, kelengkapan, kemudahan mendapatkan pelayanan, variasi model pelayanan, pelayanan pribadi, kenyamanan dalam memperoleh pelayanan, dan atribut pendukung pelayanan publik lainnya.

d. Produktivitas Pelayanan

Konsep produktivitas tidak hanya mengukur tingkat efisiensi, tetapi juga efektivitas pelayanan. Produktivitas pada umumnya dipahami sebagai rasio antara input dengan output. Konsep produktivitas dirasa terlalu sempit dan kemudian General Accounting Office (GAO) mencoba mengembangkan satu ukuran produktivitas yang lebih luas dengan memasukkan seberapa besar pelayanan publik itu memiliki hasil yang diharapkan sebagai salah satu indikator produktivitas yang penting.

Produktivitas pelayanan adalah banyaknya jumlah pelayanan yang dilakukan dengan ketersediaan tenaga pelayanan dengan memperoleh hasil pelayanan yang optimal. Memahami produktivitas pelayanan tergambar dari jumlah pelayanan publik, lama waktu pelayanan, rasio hasil pelayanan, penggunaan perangkat modern, frekuensi keluhan dan penilaian fisik.

Teori "kuantitas" dalam pelayanan publik yang diperkenalkan oleh Parasuraman, A. Valerie (2001: 66) menyatakan suatu pelayanan yang berhasil terlihat dari jumlah pelayanan yang dimanfaatkan atau dinikmati oleh publik.

Jumlah pelayanan yang bermanfaat merupakan prospektif suatu kegiatan pelayanan yang diperlukan untuk menghasilkan pelayanan yang banyak, baik dari segi materi pelayanan dan finansial pelayanan. Pelayanan yang bagus adalah yang jumlah penyelesaian pelayanan yang terselesaikan dengan menggunakan tenaga dan jam kerja yang sedikit.

Suatu produktivitas pelayanan juga terlihat dari besarnya output pelayanan yang digunakan dari sisi penggunaan lama waktu pelayanan dengan 
hasil yang menguntungkan. Penggunaan waktu yang singkat dengan hasil yang besar disebut efisiensi pelayanan produktif.

Layanan produktif selalu mempertimbangkan penggunaan waktu pelayanan dalam melihat adanya aspek kuantitas dan kualitas dari suatu pelayanan. Teori efisiensi yang diperkenalkan oleh Gareth R, Jones (2004: 95) menyatakan pelayanan adalah efisiensi waktu untuk memberikan kepuasan kepada publik dalam mendapatkan pelayanan yang terbaik.

Memperbaiki suatu pelayanan tentu diperlukan adanya suatu perbandingan antara besarnya output yang dihasilkan dengan input yang dikorbankan untuk memperoleh produktivitas pelayanan yang terbaik. Biasanya suatu pelayanan yang baik menuntut adanya rasio hasil antara nilai kualitas berbanding kuantitas. Artinya suatu pelayanan yang produktif adalah pelayanan yang menghasilkan kuantitas kerja yang lebih banyak dibandingkan dengan penggunaan jumlah korbanan kuantitas yang sedikit. Rumusan tentang produktivitas pelayanan dalam formulasi Gareth R, Jones (2004: 130) sebagai berikut.

Produktivitas=Output/Input

Dengan rumusan tersebut di atas, setiap kegiatan pelayanan yang dilakukan oleh organisasi baik pemerintah maupun non pemerintah selalu berupaya untuk menghasilkan output yang lebih besar dengan menggunakan input seminimal mungkin.

Dengan kata lain setiap organisasi dalam memberikan produktivitas pelayanan yaitu berupaya untuk meningkatkan mutu pelayanan optimal, dengan melakukan pengorbanan atau penggunaan tenaga aparat yang sedikit, seperti diformulasikan di bawah ini: (Gareth R, Jones, 2004: 131)

Produktivitas $=$ Kualitas $/$ Kuantitas

Pemahaman yang sama juga dikembangkan oleh Sastrohadiwiryo, B. Siswanto (2003) yang menyatakan bahwa produktivitas dari aspek pelayanan kerja terhadap publik tercermin dari banyaknya jumlah pelayanan yang diberikan dengan penggunaan waktu pelayanan yang sedikit. Lebih jelasnya diformulasikan:

Produktivitas = Jumlah Pelayanan/Waktu Pelayanan 
Termasuk bentuk yang sama bahwa produktivitas pelayanan adalah pencapaian hasil kerja yang dilakukan aparat dalam memberikan pelayanan publik dengan menggunakan jam kerja minimal, seperti terlihat di bawah ini:

Produktivitas $=$ Hasil Kerja/Jam Kerja

Bagi suatu organisasi produktivitas pelayanan sangat diperlukan dalam rangka pencapaian tujuan organisasi yang berbasis pelayanan. Pelayanan yang optimal akan tercapai apabila produktivitas kerja yang diperoleh akan menghasilkan output yang lebih besar dari input yang dikeluarkan.

Teori "hasil" merupakan teori dasar dalam memahami suatu kegiatan produktivitas. Biasanya kegiatan produktivitas secara kuantitatif digunakan dalam kajian ekonomi berupa hasil keuntungan yang dinyatakan dengan untung, namun kegiatan produktivitas secara kualitatif digunakan dalam kajian sosial berupa bentuk pelayanan publik yang dinyatakan dalam wujud kepuasan pelayanan.

Teori hasil menurut Gareth R, Jones (2004: 139) adalah terwujudnya serangkaian kegiatan pelayanan yang menguntungkan. Wujud keuntungan pelayanan tersebut dapat dinilai secara ekonomi dan secara sosial.

Memahami kegiatan produktivitas pelayanan dalam suatu organisasi adalah mengupayakan terwujudnya jumlah pelayanan publik, lama waktu pelayanan, rasio hasil pelayanan, penggunaan perangkat modern, frekuensi keluhan dan penilaian fisik.

e. Kualitas Pelayanan

Setiap kegiatan pelayanan publik membutuhkan adanya responsivitas aparat dalam rangka memenuhi keinginan, kebutuhan, kemauan dan harapan publik atas pelayanan dalam rangka memperbaiki citra pemerintah sebagai pelayan publik.

Beberapa pandangan yang menjadi teori dan konsep mengenai responsivitas pelayanan yang dapat dipahami dalam berbagai tinjauan lapangan dalam kegiatan pelayanan di publik antara lain menggunakan teori "sadar", teori "perilaku", teori "jaminan" dan teori "harapan". Teori-teori ini merupakan dasar dalam melihat suatu aplikasi responsivitas pelayanan publik yang diterapkan oleh aparat. 
Dalam organisasi pemerintah, inti dari segala kegiatan yang dilakukan adalah pelayanan. Aparat sebagai pengembang pelayanan publik harus dituntut memiliki kesadaran. Gaspersz, V. (2004: 195) responsivitas pelayanan mengutamakan kesadaran yang tinggi tentang bentuk pelayanan yang diberikan kepada publik.

Kesadaran merupakan kunci keberhasilan aparat dalam memajukan dan mengembangkan suatu kegiatan pelayanan publik untuk mencapai tujuan organisasi. Serangkaian kegiatan dalam pencapaian suatu tujuan harus ditopang oleh kesadaran yang tinggi dalam menjalankan aktivitas pelayanan.

Hal ini tentu mempunyai keterkaitan dengan perilaku aparat pemerintah untuk mengembangkan berbagai hal yang berkaitan dengan Kesadarannya, yang secara khusus berkaitan dengan kesadaran berperilaku dalam memberikan pelayanan yang terbaik kepada publik. Teori kebijaksanaan merupakan suatu teori yang dikembangkan oleh Lippman dalam Santosa, Pandji (2008: 94) menyatakan keberhasilan pelayanan ditentukan oleh adanya perilaku bijak untuk menghasilkan kebijaksanaan pelayanan yang optimal.

Pelayanan yang bijaksana akan terwujud apabila setiap aparat pelaksana pelayanan memiliki perilaku yang sadar dalam mengembang kegiatan pelayanan yang sesuai dengan bentuk-bentuk perbaikan pelayanan yang diupayakan dengan optimal. Memahami pentingnya perbaikan pelayanan, teori inti menjadi penting untuk diterapkan. Teori ini diperkenalkan oleh Lippman dalam Santosa, Pandji (2008: 103) menyatakan perbaikan pelayanan menjadi inti dari intensitas pelayanan yang memuaskan.

Inti pelayanan yang dimaksud adalah mengembangkan segala unsur pelayanan yang responsivitas terhadap kegiatan pelayanan. Inti responsivitas pelayanan pada prinsipnya adalah memberikan pelayanan dengan baik untuk meminimalkan adanya keluhan pelayanan, menunjukkan aktualisasi diri secara sempurna dalam memberikan pelayanan kepada publik, membuat suatu pelayanan yang memiliki kesan dan daya tarik, memberikan pelayanan yang memuaskan baik secara intrinsik dan ekstrinsik serta menjadikan pelayanan sebagai ujung tombak dari keberhasilan organisasi.

Memahami inti suatu pelayanan juga sangat terkait dengan kepuasan pelayanan. Wujud kepuasan pelayanan dapat dilihat dari teori "gap" yang diperkenalkan oleh Rangkuti, Freddy (2004: 40) kepuasan terhadap suatu jasa 
ditentukan oleh tingkat kepentingan sebelum menggunakan jasa dibandingkan dengan hasil persepsi terhadap jasa tersebut setelah publik merasakan jasa tersebut. Lebih jelasnya dapat dilihat pada gambar berikut.

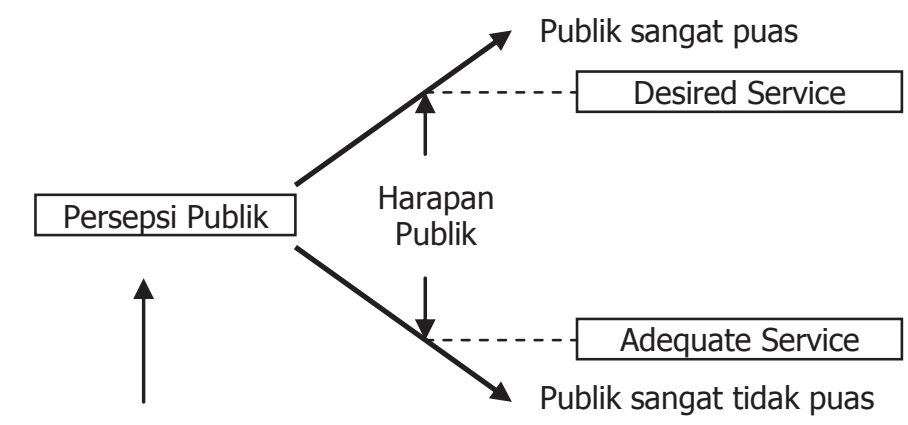

Perceived Service (Service yang diterima Publik)

Gambar 2.16 Proses kepuasan pelanggan (Rangkuti, Freddy, 2004: 40)

Salah satu faktor yang menentukan kepuasan publik adalah kualitas pelayanan yang terdiri dari 5 dimensi pelayanan. Kesenjangan merupakan ketidaksesuaian antara pelayanan yang dipersepsikan (perceived service) dan pelayanan yang diharapkan (expected service).

\section{Expected Service}

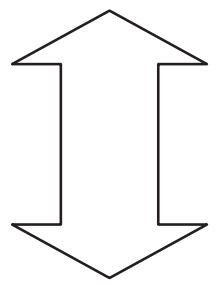

\section{GAP}

\section{Perceived Service}

Gambar 2.17 Kesenjangan yang dirasakan oleh pelanggan (Rangkuti, Freddy (2004: 42))

Engel, James (1990: 23) kepuasan adalah perasaan senang atau kecewa seseorang yang berasal dari perbandingan antara kesannya terhadap hasil suatu jasa dan harapan-harapannya. Kepuasan merupakan fungsi dari kesan 
kinerja dan harapan. Jika kinerja berada di bawah harapan, pelanggan akan tidak puas. Jika kinerja melebihi harapan, maka pelanggan akan merasa amat puas atau senang. Dalam kaitan itu, maka faktor kepuasan pelanggan (customer satisfaction) menjadi elemen penting dalam memberikan atau menambah nilai bagi pelanggan.

Salah satu pendekatan yang paling populer yang berhubungan dengan kepuasan pelanggan adalah teori The Expectancy Disconfirmation Model dari Zeithaml (1990: 167). Lebih jelasnya dapat dilihat pada model di bawah ini:

- Komunikasi dari Mulut ke Mulut

- Kebutuhan Pribadi

- Pengalaman Masa Lalu

- Komunikasi Eksternal

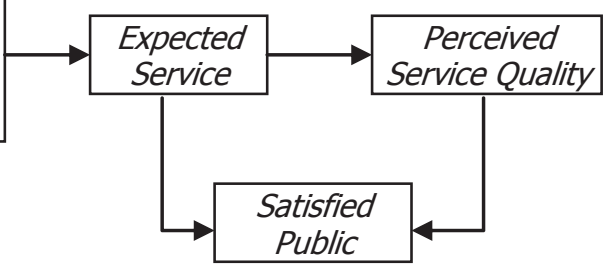

Gambar 2.18 Model expectancy disconfirmation (Zeithaml, et. al, 1990: 67))

Teori ini menekankan bahwa kepuasan atau ketidakpuasan ditentukan oleh suatu proses evaluasi publik, dimana persepsi tersebut mengenai hasil suatu jasa atau jasa dibandingkan dengan standar yang diharapkan. Proses inilah yang disebut dengan proses diskonfirmasi. Kesenjangan terjadi apabila publik mempersepsikan pelayanan yang diterimanya lebih tinggi daripada desired service atau lebih rendah daripada adequate service kepentingan publik tersebut. Dengan demikian, publik dapat merasakan sangat puas atau sebaliknya sangat kecewa.

Zeithaml, et. Al. (1990: 42) model perceptual mengenai kualitas pelayanan dapat menjelaskan proses terjadinya kesenjangan atau ketidaksesuaian antara keinginan dan tingkat kepentingan berbagai pihak yang terlibat dalam penyerahan jasa/jasa. Untuk detailnya dapat dilihat Gambar berikut. 


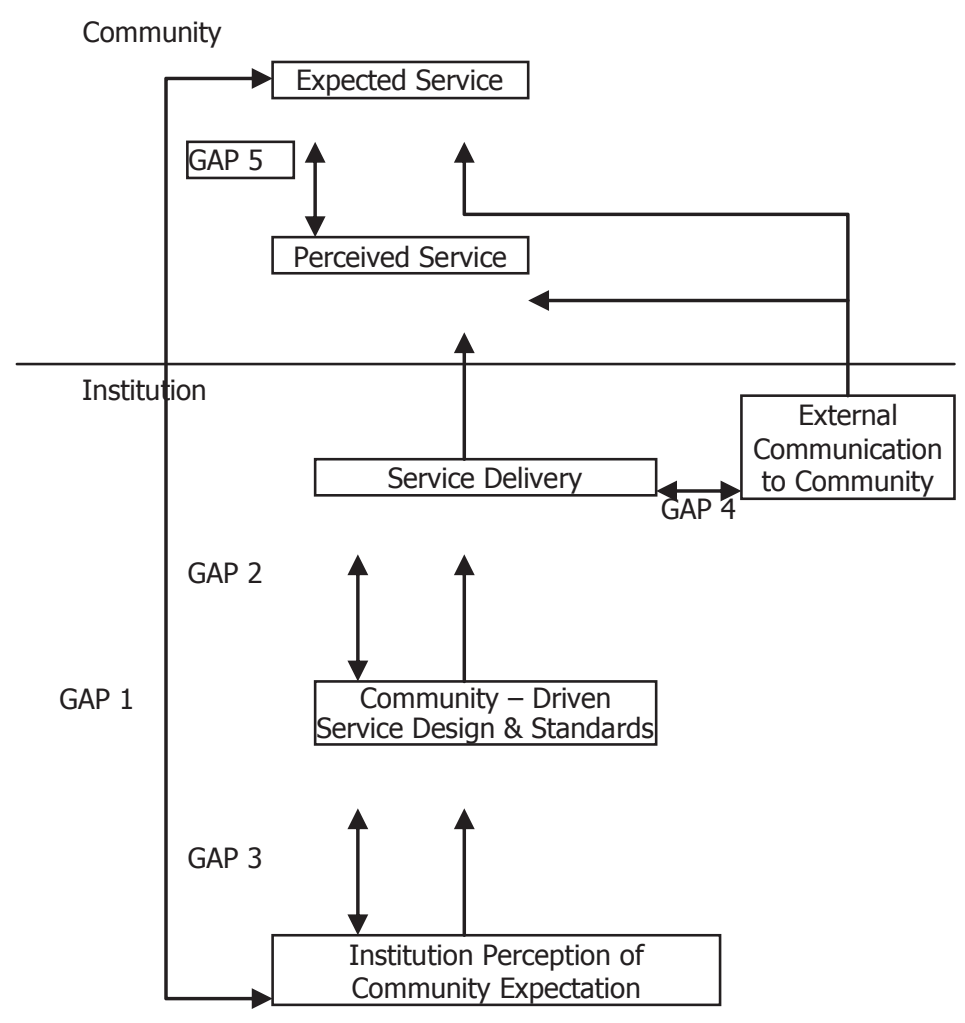

Gambar 2.19 Model gap service quality (Zeithaml, et. Al. 1990: 43)

Berdasarkan gaps model of service quality di atas, ketidaksesuaian muncul dari lima macam kesenjangan yang dapat dibagi menjadi dua kelompok, yaitu:

1. Satu kesenjangan (gap), yaitu kesenjangan kelima yang bersumber dari sisi penerima pelayanan (publik).

2. Empat macam kesenjangan, yaitu kesenjangan pertama sampai dengan empat, bersumber dari penyedia jasa (manajemen).

Kepuasan publik dapat dinyatakan sebagai suatu rasio atau perbandingan dengan merumuskan persamaan kepuasan publik sebagai berikut: $Z=X / Y$, dimana $Z$ adalah kepuasan publik, $X$ adalah kualitas yang dirasakan oleh publik dan $Y$ adalah kebutuhan, keinginan dan harapan publik. Jika publik merasakan bahwa kualitas pelayanan jasa melebihi kebutuhan, keinginan dan harapannya, maka kepuasan publik akan menjadi tinggi atau paling sedikit bernilai lebih besar dari satu $(Z>1)$. Sedangkan pada sisi lain, 
apabila publik merasakan bahwa kualitas dari jasa lebih rendah atau lebih kecil dari kebutuhan, keinginan dan harapannya, maka kepuasan publik menjadi sangat tergantung pada persepsi dan ekspektasi publik.

Faktor-faktor yang mempengaruhi kepuasan dan ekspektasi publik menurut Gaspersz, V. (2004: 35) terdiri dari:

1. "Kebutuhan dan keinginan" yang berkaitan dengan hal-hal yang dirasakan publik ketika ia sedang mencoba melakukan transaksi dengan produsen jasa. Jika pada saat itu kebutuhan dan keinginannya besar, harapan atau ekspektasi publik akan tinggi, demikian pula sebaliknya.

2. Pengalaman masa lalu (terdahulu) ketika menggunakan jasa pelayanan dari organisasi jasa maupun pesaing-pesaingnya.

3. Pengalaman dari teman-teman, yang menceritakan mengenai kualitas pelayanan jasa yang dirasakan oleh pelanggan itu. Hal ini jelas mempengaruhi persepsi publik terutama pada jasa-jasa yang dirasakan berisiko tinggi.

4. Komunikasi melalui iklan dan pemasaran juga mempengaruhi publik. Orang-orang di bagian penjualan dan periklanan seyogyanya tidak membuat kampanye yang berlebihan melewati tingkat ekspektasi publik. Kampanye yang berlebihan dan secara aktual tidak mampu memenuhi ekspektasi publik akan mengakibatkan dampak negatif terhadap persepsi publik tentang pelayanan jasa yang diberikan.

Penyelenggaraan suatu pelayanan, baik kepada publik internal maupun eksternal, pihak penyedia dan pemberi pelayanan harus selalu berupaya untuk mengacu kepada tujuan utama pelayanan yaitu kepuasan (satisfaction).

Teori "prima" yaitu sebuah teori tentang keutamaan pelayanan. Keutamaan pelayanan tersebut dikembangkan berdasarkan postula bahwa publik adalah raja yang harus dilayani dengan sepenuh hati. Akibat melalaikan suatu pelayanan prima akan berdampak terhadap lemahnya suatu sistem pelayanan. Pelayanan prima akan kuat apabila kode etik yang mendasari dalam menentukan responsibilitas pelayanan. Westra, Wasistiono (1999: 155) pelayanan prima adalah pelayanan yang utama dan terutama untuk kebutuhan publik. 
Responsivitas adalah kemampuan birokrasi untuk mengenai kebutuhan publik, menyusun agenda dan prioritas pelayanan, serta mengembangkan program-program pelayanan sesuai dengan kebutuhan dan aspirasi publik. Secara singkat dapat dikatakan bahwa responsivitas ini mengukur daya tanggap birokrasi terhadap harapan, keinginan dan aspirasi, serta tuntutan pengguna jasa. Responsivitas sangat diperlukan dalam pelayanan publik karena hal tersebut merupakan bukti kemampuan organisasi untuk mengenali kebutuhan publik, menyusun agenda dan prioritas pelayanan serta mengembangkan program-program pelayan publik sesuai dengan kebutuhan dan aspirasi publik (Dilulio, Ussell, 1991). Organisasi yang memiliki responsivitas rendah dengan sendirinya memiliki kinerja yang jelek juga (Osborne, David Plastrik and Peter, 1997).

Dalam operasionalisasinya, responsivitas pelayanan publik dijabarkan menjadi beberapa indikator, seperti meliputi (1) terdapat tidaknya keluhan dan pengguna jasa selama satu tahun terakhir; (2) sikap aparat birokrasi dalam merespons keluhan dan pengguna jasa; (3) penggunaan keluhan dan pengguna jasa sebagai referensi bagi perbaikan penyelenggaraan pelayanan pada masa mendatang (4) berbagai tindakan aparat birokrasi untuk memberikan kepuasan pelayanan kepada pengguna jasa; serta (5) penempatan pengguna jasa oleh aparat birokrasi dalam sistem pelayanan yang berlaku. Keluhan yang disampaikan oleh publik pengguna jasa merupakan indikator pelayanan yang memperlihatkan bahwa produk pelayanan yang selama ini dihasilkan oleh birokrasi belum dapat memenuhi harapan pengguna layanan.

Responsivitas birokrasi yang rendah juga banyak disebabkan oleh belum adanya pengembangan komunikasi eksternal secara nyata oleh jajaran birokrasi pelayanan. Indikasi nyata dari belum dikembangkannya komunikasi eksternal secara efektif oleh birokrasi terlihat pada masih besarnya gap pelayanan yang terjadi.

Gap pelayanan yang terjadi merupakan gambaran pelayanan yang memperlihatkan bahwa belum ditemukan kesamaan persepsi antara harapan pengguna jasa dan pemberi layanan terhadap kualitas pelayanan yang diberikan. Aparat birokrasi pelayanan di ketiga daerah penelitian terlihat masih membuka jurang komunikasi yang lebar dengan publik pengguna jasa. Tidak transparannya aparat birokrasi pelayanan pertanahan, misalnya, 
merupakan salah satu indikasi belum adanya pengembangan komunikasi eksternal di kalangan aparat birokrasi dengan publik pengguna jasa. Tidak transparannya komunikasi dan birokrasi yang menyangkut pemberian pelayanan menyebabkan pihak publik pengguna jasa selalu berada pada posisi yang demikian.

Tidak adanya transparansi informasi dari birokrasi tersebut membuat banyak publik pengguna jasa mengalami frustasi. Komunikasi yang tidak efektif yang selama ini masih dikembangkan oleh birokrasi menunjukkan bahwa birokrasi belum mempunyai kesadaran untuk meningkatkan kualitas pelayanan kepada publik pengguna jasa. Responsivitas pemberian pelayanan publik salah satunya diukur melalui keterbukaan informasi dan seberapa jauh interaksi komunikasi yang terjalin antara birokrasi sebagai pemberi layanan dengan publik pengguna jasa. Kasus di atas memperlihatkan gambaran bahwa publik pengguna jasa seringkali belum mempunyai akses terhadap informasi pelayanan yang dibutuhkan, demikian pula kecenderungan aparat birokrasi justru terkesan menyembunyikan informasi kepada publik. Dalam iklim komunikasi pelayanan yang tertutup seperti ini, sangat sulit untuk dapat mewujudkan responsivitas aparat birokrasi dalam penyelenggaraan pelayanan kepada publik.

Konsep kualitas layanan pada dasarnya memberikan persepsi secara konkrit mengenai kualitas suatu layanan. Konsep kualitas layanan ini merupakan suatu revolusi secara menyeluruh, permanen dalam mengubah cara pandang manusia dalam menjalankan atau mengupayakan usahausahanya yang berkaitan dengan proses dinamis, berlangsung, terus menerus di dalam memenuhi harapan, keinginan dan kebutuhan. Hal ini sesuai dengan teori "Quality" yang dikemukakan oleh Gaspersz, V. (2004: 192) bahwa keberhasilan suatu tindakan jasa ditentukan oleh kualitas. Kualitas merupakan apresiasi tertinggi dari tindakan pelayanan.

Gaspersz, V. (2004: 210) menyatakan bahwa konsep kualitas layanan adalah suatu persepsi tentang revolusi kualitas secara menyeluruh yang terpikirkan dan menjadi suatu gagasan yang harus dirumuskan (formulasi) agar penerapannya (implementasi) dapat diuji kembali (evaluasi), untuk menjadi suatu proses yang dinamis, berlangsung, terus menerus dalam memenuhi kepuasan publik. Teori "tujuan" yang dikembangkan oleh 
Gaspersz, V. (2000: 84) bahwa tujuan adalah asumsi kepuasan yang disesuaikan dengan tingkat kualitas pelayanan.

Konsep kualitas layanan pada dasarnya suatu standar kualitas yang harus dipahami di dalam memberikan pelayanan yang sebenarnya tentang pemasaran dengan kualitas layanan. Hal tersebut bukan hanya bersifat cerita atau sesuatu yang mengada-ada, tetapi harus disesuaikan dengan suatu standar yang layak, seperti standar ISO (International Standardization Organization), sehingga dianggap sebagai suatu kondisi yang sehat untuk tujuan atau pemakaian, memiliki keselarasan dengan spesifikasi, kebebasan dengan segala kekurangannya, membentuk kepuasan publik, memiliki kredibilitas yang tinggi dan merupakan kebanggaan.

Yong, C.Z., Yun, Y.W., Loh, L. (2003: 146) memberikan suatu pengertian bahwa konsep kualitas layanan adalah suatu kecocokan untuk penggunaan (fitness for yours) yang bertujuan untuk menemukan suatu pemikiran yang jelas dari proses pemikiran yang melahirkan adanya suatu pemahaman yang tidak sulit untuk dipahami, karena elusive goal (tujuannya jelas) dan prosesnya merupakan continue quality improvement (proses yang berkelanjutan).

Tinjauan mengenai konsep kualitas layanan sangat ditentukan oleh berapa besar kesenjangan (gap) antara persepsi publik atas kenyataan pelayanan yang diterima, dibandingkan dengan harapan publik atas pelayanan yang harus diterima. Menurut Parasuraman, A. Valerie (2001: 162) bahwa konsep kualitas layanan yang diharapkan dan dirasakan ditentukan oleh dimensi kualitas pelayanan.

Dimensi kualitas pelayanan tersebut terdiri dari bukti fisik, empati, kehandalan, daya tanggap dan jaminan. Selain itu, pelayanan yang diharapkan sangat dipengaruhi oleh berbagai persepsi komunikasi dari mulut ke mulut, kebutuhan pribadi, pengalaman masa lalu dan komunikasi eksternal, persepsi inilah yang mempengaruhi pelayanan yang diharapkan (Ep = Expectation) dan pelayanan yang dirasakan ( $\mathrm{Pp}=$ Perception) yang membentuk adanya konsep kualitas layanan.

Parasuraman, A. Valerie (2001: 165) menyatakan bahwa konsep kualitas layanan merupakan suatu pengertian yang kompleks tentang mutu, tentang memuaskan atau tidak memuaskan. Kapan dikatakan konsep kualitas layanan bermutu apabila melebihi pelayanan yang diharapkan lebih kecil dari pelayanan yang dirasakan (bermutu). Dikatakan konsep kualitas layanan 
memenuhi harapan, apabila pelayanan yang diharapkan sama dengan yang dirasakan (memuaskan). Demikian pula dikatakan persepsi tidak memenuhi harapan apabila pelayanan yang diharapkan lebih besar daripada pelayanan yang dirasakan (tidak bermutu).

Konsep kualitas layanan dari harapan yang diharapkan seperti dikemukakan di atas, ditentukan oleh empat faktor, yang saling terkait dalam memberikan suatu persepsi yang jelas dari harapan publik dalam mendapatkan pelayanan. Keempat faktor tersebut adalah:

1) Komunikasi dari mulut ke mulut (word of mouth communication), faktor ini sangat menentukan dalam pembentukan harapan publik atas suatu jasa/pelayanan. Pemilihan untuk mengkonsumsi suatu jasa/pelayanan yang bermutu dalam banyak kasus dipengaruhi oleh informasi dari mulut ke mulut yang diperoleh dari publik yang telah mengkonsumsi jasa tersebut sebelumnya.

2) Kebutuhan pribadi (personal need), yaitu harapan publik bervariasi tergantung pada karakteristik dan keadaan individu yang mempengaruhi kebutuhan pribadinya.

3) Pengalaman masa lalu (past experience), yaitu pengalaman publik merasakan suatu pelayanan jasa tertentu di masa lalu mempengaruhi tingkat harapannya untuk memperoleh pelayanan jasa yang sama di masa kini dan yang akan datang.

4) Komunikasi eksternal (company's external communication) yaitu komunikasi eksternal yang digunakan oleh organisasi jasa jasa sebagai pemberi pelayanan melalui berbagai bentuk upaya promosi juga memegang peranan dalam pembentukan harapan publik.

Berdasarkan pengertian di atas terdapat tiga tingkat konsep kualitas layanan yaitu:

1) Bermutu (quality surprise), bila kenyataan pelayanan yang diterima melebihi pelayanan yang diharapkan publik.

2) Memuaskan (satisfactory quality), bila kenyataan pelayanan yang diterima sama dengan pelayanan yang diharapkan publik.

3) Tidak bermutu (unacceptable quality), bila ternyata kenyataan pelayanan yang diterima lebih rendah dari yang diharapkan publik. 
Uraian tersebut di atas, menjadi suatu penilaian di dalam menentukan berbagai macam model pengukuran kualitas pelayanan. Menurut Peter (2003: 99) menyatakan bahwa untuk mengukur konsep kualitas layanan, maka dilihat dari enam tinjauan yang menjadi suatu penilaian dalam mengetahui konsep kualitas layanan yang diadopsi dari temuan-temuan hasil penelitian antara lain sebagai berikut:

1) Gronroos Perceived Service Quality Model yang dibuat oleh Gronroos. Pendekatan yang dilakukan adalah dengan mengukur harapan akan kualitas pelayanan (expected quality) dengan pengalaman kualitas pelayanan yang diterima (experienced quality) dan antara kualitas teknis (technical quality) dengan kualitas fungsi (functional quality). Titik fokus dalam perbandingan itu menggunakan citra organisasi jasa (corporate image) pemberi jasa. Citra organisasi jasa menurut Gronroos, Michael (1990: 55) sangat mempengaruhi harapan dan pengalaman publik, sehingga dari keduanya akan melahirkan konsep kualitas layanan secara total.

2) Heskett's Service Profit Chain Model. Model ini dikembangkan oleh Heskett's dalam Marcel, Davidson (2003) dengan membuat rantai nilai profit. Dalam rantai nilai tersebut dijelaskan bahwa kualitas pelayanan internal (internal quality service) lahir dari aparat yang puas (employee satisfaction). Aparat yang puas akan memberi dampak pada ketahanan aparat (employee retention) dan produktivitas aparat (employee productivity), yang pada gilirannya akan melahirkan kualitas pelayanan eksternal yang baik. Kualitas pelayanan eksternal yang baik akan melahirkan kepuasan publik (customer satisfaction), loyalitas publik (customer loyalty), dan pada akhirnya meningkatkan profitabilitas.

3) Normann's Service Management System. Model ini dikembangkan oleh Norman, Davis (2004: 45) yang menyatakan bahwa sesungguhnya jasa itu ditentukan oleh partisipasi dari publik, dan evaluasi terhadap kualitas pelayanan tergantung pada interaksi dengan publik. Sistem manajemen pelayanan bertitik tolak pada budaya dan filosofi yang ada dalam suatu organisasi jasa.

4) European Foundation for Quality Management Model (EFQM Model). Model ini dikembangkan oleh Yayasan Eropa untuk Management Mutu dan telah diterima secara internasional. Model ini ditemukan setelah 
lembaga tersebut melakukan survei terhadap organisasi jasa yang sukses di Eropa. Organisasi dan hasil (organization and results) merupakan titik tolak model ini, di mana kualitas pelayanan ditentukan oleh faktor kepemimpinan (leadership) dalam mengelola sumberdaya manusia, strategi dan kebijakan, dan sumberdaya lain yang dimiliki organisasi. Proses secara baik terhadap faktor-faktor tersebut akan melahirkan kepuasan kepada aparat, kepuasan kepada publik dan dampak sosial yang berarti, dan ketiganya merupakan hasil yang sebenarnya.

5) Service Performance Model (SERPERF Model). Model ini dikembangkan oleh Cronin dan Taylor yang mengukur tingkat kualitas pelayanan berdasarkan apa yang diharapkan oleh publik (expectation) dibandingkan dengan ukuran kinerja (performance) yang diberikan oleh organisasi dan derajat kepentingan (importance) yang dikehendaki oleh publik (Tjiptono, Fandy, 2003: 99).

6) Service Quality Model (SERVQUAL Model). Model ini dikembangkan oleh Parasuraman, Zeithaml dan Berry. Pengukuran dalam model ini menggunakan skala perbandingan multidimensional antara harapan (expectation) dengan persepsi tentang kinerja (performance).

Uraian tersebut di atas memberikan suatu pemahaman yang kuat bahwa di dalam menumbuhkan adanya konsep kualitas layanan kepada publik, maka aparat harus menumbuhkan dan memberikan kekuatan terhadap pentingnya kualitas pelayanan yang diberikan. Sesungguhnya kualitas pelayanan merupakan kualitas interaksi, kualitas lingkungan fisik dan kualitas hasil yang diterima oleh publik dalam rangka memenuhi tingkat kepuasannya.

Berdasarkan pengertian dasar tentang kualitas di atas, tampak bahwa kualitas selalu berfokus pada pelayanan publik (customer service focused quality). Dengan demikian jasa-jasa di desain serta pelayanan diberikan untuk memenuhi keinginan publik. Karena kualitas mengacu kepada segala sesuatu yang menentukan kepuasan publik, suatu jasa yang dihasilkan baru dikatakan berkualitas apabila sesuai dengan keinginan publik, dimanfaatkan dengan baik, serta dihasilkan dengan cara yang baik dan benar.

Tinjauan Parasuraman, A. Valerie (2001: 152) menyatakan bahwa di dalam memperoleh kualitas pelayanan jasa yang optimal, banyak ditentukan oleh kemampuan di dalam memadukan unsur-unsur yang saling berkaitan di 
dalam menunjukkan adanya suatu layanan yang terpadu dan utuh. Suatu kualitas pelayanan jasa akan komparatif dengan unsur-unsur yang mendukungnya, yaitu: (1) adanya jasa yang sesuai dengan bentuk pelayanan yang dapat memberikan kepuasan kepada publik, (2) penyampaian informasi yang kompleks, terformalkan dan terfokus di dalam penyampaiannya, sehingga terjadi bentuk-bentuk interaksi antara pihak yang memberikan pelayanan jasa dan yang menerima jasa, dan (3) memberikan penyampaian bentuk-bentuk kualitas pelayanan jasa sesuai dengan lingkungan jasa yang dimiliki oleh suatu organisasi jasa.

Ini menunjukkan bahwa organisasi yang maju senantiasa mengedepankan bentuk-bentuk aktualisasi kualitas pelayanan. Kualitas pelayanan yang dimaksud adalah memberikan bentuk pelayanan yang optimal dalam memenuhi kebutuhan, keinginan, harapan dan kepuasan dari publik yang meminta pelayanan dan yang meminta dipenuhi pelayanannya. Parasuraman, A. Valerie (2001: 26) mengemukakan konsep kualitas pelayanan yang berkaitan dengan kepuasan ditentukan oleh lima unsur yang biasa dikenal dengan istilah dimensi kualitas pelayanan "TERRA" (tangible, empathy, reliability, responsiveness, assurance). Konsep kualitas pelayanan TERRA intinya adalah membentuk sikap dan perilaku dari pengembang pelayanan untuk memberikan bentuk pelayanan yang kuat dan mendasar, agar mendapat penilaian sesuai dengan kualitas layanan yang diterima.

Inti dari konsep kualitas pelayanan adalah menunjukkan segala bentuk aktualisasi kegiatan pelayanan yang memuaskan orang-orang yang menerima pelayanan sesuai dengan penunjukkan bukti fisik (tangible) yang dapat dilihatnya, menurut empati (empathy) dari orang-orang yang memberikan pelayanan sesuai dengan kehandalannya (reliability) menjalankan tugas pelayanan, cepat dalam daya tanggap (responsiveness), menumbuhkan adanya jaminan (assurance), yang diberikan secara konsekuen untuk memuaskan yang menerima pelayanan.

Berdasarkan inti dari konsep dimensi kualitas pelayanan "TERRA" kebanyakan organisasi kerja yang menjadikan konsep ini sebagai acuan dalam menerapkan aktualisasi layanan dalam organisasi kerjanya, dalam memecahkan berbagai bentuk kesenjangan (gap) atas berbagai pelayanan yang diberikan oleh pegawai dalam memenuhi tuntutan pelayanan publik. Aktualisasi konsep "TERRA" juga diterapkan dalam penerapan kualitas pelayanan pegawai. 


\section{BAGIAN VIII}

PENUTUP

Pada prinsipnya perspektif proses pengadaan dan pemeliharaan barang/jasa pada sektor pemerintahan umumnya telah berjalan baik dalam kondisi transaksi maupun non transaksional. Berkaitan dengan proses pengadaan ATK dapat dinyatakan bahwa hal tersebut berkaitan dengan perspektif dan dimensi pemilihan penyedia jasa pengadaan ATK dengan cara penunjukan langsung terdiri atas undangan kepada peserta terpilih dilampiri dokumen pengadaan; Pemasukan dokumen kualifikasi; Evaluasi kualifikasi; Pemberian penjelasan; Pemasukan dokumen penawaran; Evaluasi penawaran serta klarifikasi dan negosiasi teknis dan harga; Penetapan pemenang; Pengumuman pemenang; Penunjukan penyedia barang/jasa.

Sementara itu bahwa pelaksanaan pengadaan ATK terdiri atas pejabat pengadaan barang melakukan pemeriksaan stok barang, menaksir kebutuhan barang, koordinasi dengan penyedia barang ATK, datangkan barang, pemeriksaan barang, membuat daftar serah terima barang, pembayaran dan pengambilan bukti pembayaran. Pelaporan pengadaan ATK terdiri atas penyusunan laporan, penggandaan laporan dan penyerahan laporan kegiatan pemeliharaan kendaraan dinas. Proses pemeliharaan kendaraan dinas adalah proses pemilihan penyedia jasa pemeliharaan kendaraan dinas yang terdiri atas pengumuman prakualifikasi; pendaftaran dan pengambilan dokumen kualifikasi; pemasukan dan evaluasi dokumen kualifikasi; pembuktian kualifikasi; penetapan hasil kualifikasi; pengumuman hasil kualifikasi; sanggahan kualifikasi; undangan; pengambilan dokumen pemilihan; pemberian penjelasan; pemasukan dokumen penawaran tahap I; Pembukaan dokumen penawaran tahap I; evaluasi dokumen penawaran tahap I; penetapan peserta yang lulus evaluasi tahap I; pemberitahuan/ pengumuman peserta yang lulus evaluasi tahap I; pemasukan dokumen penawaran tahap II; pembukaan dokumen penawaran tahap II; evaluasi dokumen penawaran tahap II; pembuatan berita acara hasil pelelangan; penetapan pemenang; pengumuman pemenang; sanggahan; sanggahan banding (apabila diperlukan); penunjukan penyedia barang/jasa.

Proses pelaksanaan pemeliharaan kendaraan dinas yang terdiri atas pejabat pengadaan barang/jasa memeriksa kerusakan kendaraan dan menaksir biaya perbaikan; koordinasi dengan penyedia jasa perbaikan, pemeriksaan kendaraan; penentuan biaya dan kesepakatan harga; perbaikan/ pemeliharaan kendaraan; melaksanakan perbaikan; evaluasi hasil perbaikan; pembayaran dan pengambilan bukti 
pembayaran lalu diserahkan ke pejabat pengadaan barang. Proses pelaporan pengadaan pemeliharaan kendaraan dinas terdiri atas penyusunan laporan, penggandaan laporan dan penyerahan laporan kegiatan pemeliharaan kendaraan dinas.

Proses pengadaan barang dan jasa ditinjau dari teori pendekatan teori asymetric information, opportunity behavior dan efficiency economic value adalah mendukung proposisi penelitian yaitu semakin tinggi asymetric information maka semakin rendah kualitas pelayanan organisasi kepada publik; Semakin tinggi opportunity behavior, maka semakin tinggi kualitas pelayanan organisasi kepada publik dan semakin tinggi efficiency economic value, maka semakin tinggi kualitas pelayanan organisasi kepada publik.

Proses pengadaan ATK melalui penunjukan langsung dan proses pemeliharaan kendaraan dinas melalui pelelangan umum adalah tidak efisien dan tidak efektif. Peningkatan efisiensi dan efektivitas dapat dilakukan melalui penunjukan langsung penyedia barang/jasa.

Pengadaan barang/jasa pada Biro Keuangan dan Kekayaan Sekretariat Daerah Provinsi Maluku cukup banyak, namun dalam penelitian ini hanya difokuskan pada pengadaan barang ATK dan jasa pemeliharaan kendaraan dinas. Untuk itu perlu dilakukan pengembangan penelitian ini dengan melakukan penelitian biaya transaksi pengadaan barang/jasa yang lainnya. Selain itu, perlu dilakukan penelitian yang sama pada instansi pemerintah yang lain selain Biro Keuangan dan Kekayaan Sekretariat Daerah Provinsi Maluku bahkan pada perusahaan swasta. Pengembangan penelitian tersebut akan lebih melengkapi dan memperkaya hasil penelitian tentang biaya transaksi.

Memperhatikan proses pengadaan ATK melalui metode penunjukan langsung penyedia barang adalah lebih panjang dari pada pengadaan langsung. Selain itu metode penunjukan langsung penyedia barang ATK tidak efisien dan tidak efektif. Untuk itu diharapkan kepada penentu kebijakan agar merubah metode penunjukan langsung menjadi pengadaan langsung dalam pemilihan penyedia barang ATK.

Memperhatikan proses pemeliharaan kendaraan dinas melalui metode pelelangan umum penyedia barang/jasa adalah lebih panjang dari pada pengadaan langsung. Selain itu metode pelelangan umum penyedia barang/jasa pemeliharaan kendaraan dinas tidak efisien dan tidak efektif. Untuk itu diharapkan kepada penentu kebijakan agar merubah metode pelelangan umum menjadi pengadaan langsung dalam pemilihan penyedia barang/jasa pemeliharaan kendaraan dinas. 
Demikian pula bahwa metode pemilihan penyedia barang/jasa ditempuh untuk meminimasi proses dan biaya transaksi serta hasil pengadaan barang/jasa yang lebih baik dibanding penunjukan langsung atau pelelangan umum. Perubahan tersebut tidak boleh dilakukan untuk menghindari pajak dan mencari keuntungan pribadi, akan tetapi demi penyederhanaan proses, peningkatan efisiensi dan efektivitas biaya transaksi. Sehingga dapat menciptakan iklim organisasi birokrasi dalam proses persaingan yang sehat. 



\section{DAFTAR PUSTAKA}

Alma, Buchari. 2010. Kewirausahaan. Alfa Beta, Bandung

Angraini, Eva. 2005. Analisis Biaya Transaksi dan penerimaan nelayan dan petani di Pelabuhan Ratu Kab. Sukabumi. Tesis IPB, Bogor

Albrow, Martin, 1989. Birokrasi. Terjemahan. Penerbit PT. Tiara Wacana Yogya, Yogyakarta.

Alonso, Malic, 2009. How to Managed of Organization Effectiveness. New Jersey, Prentice Hall

Ansari, Muhammad Sadiq, 2006, An Empirical Investigation of Cost Efficiency in the Banking Sector of Pakistan. SBP Working Paper Series No.12 June 2006, State Bank Of Pakistan, Karachi.

Anshari, Haninpraja, 2003. Penerapan Efisiensi Pelayanan Prima. Penerbit Boedi Ilmu, Malang.

Anshory, Amir, 2005. Pelayanan Publik dalam Perspektif Administrasi. Penerbit Rineka Cipta, Jakarta.

Ashilah, Zahrani, 2003. Kualitas Pelayanan Masyarakat dalam Kepuasan Masyarakat. Penerbit Bina Harapan Ilmu, Surabaya.

Boeyong, Soetanto, 2001. Standar Pelayanan Minimal: Tinjauan Ekonomis dalam Keterjangkauan Biaya Pelayanan. Penerbit Rineka Cipta, Jakarta

Birl, Higgins, 2003. Public Service and Policy Implementation in The Third World. Princeton University Press.

Black, Shafritz, 2007. Classics of Public Administration, USA: Harcourt Brace \& Company

Bromley, Daniel W. 1982. Land and Water Problems: An Institutional Perspective. American Journal of Agricultural Economics 64: 834-44.

Carlos, Samuelson, 2006. The Network Service of Public. Published by Prentice Hall Ohio Press

Demmand, Knoke, 2006. Altematif of Public Service. London: Sage Publication.

Dilulio, Ussell, 1991. Administration Management, Mc Grow-Hill, inc., Singapura

Engel, James, 1990. Satisfaction; A Behavioral Perspective On The Consumer. Mc-Graw Hill Companies Inc., USA. (Diterjemahkan oleh Purwoko).

Frederickson, H. George, 1997. Public Administration Theory Primer. Kumarin Press, New York.

Gareth R, Jones, 2004. Management Organization. Prentice Hall, Ohio University. 
Gaspersz, V. 2004. Manajemen Kualitas: Penerapan Konsep-konsep Kualitas dalam Manajemen Bisnis Total. Kerjasama Yayasan Indonesia Emas Gramedia Pustaka Utama, Jakarta.

Genugten, Maria Lambetta Van. 2008. Transaction Cost Economics and The Provision of Public Services at The Local Level

Gibson, Ivancevich Donnelly, 1997. Organisasi: Perilaku Struktur Proses. Edisi Revisi, Penerbit Binarupa Aksara, Jakarta.

Gopar, Achmad H. 2010. Analisis Biaya Transaksi Pada Kredit Usaha Rakyat. Jurnal Pengkajian Koperasi dan UKM, Deputi Bidang Pengkajian Sumberdaya UKMK, Kementerian Koperasi dan UKM, Jakarta. Volume V Agustus 2010

Gronroos, Michael, 1990. Perceived Service Quality Model. Published Ohio University Press, California.

Guricci, Guntur, 2002. Pentingnya Ketepatan Waktu dalam Pelayanan Kerja. Penerbit Sinar Ilmu, Bandung

Hellriegel, Thomas G, 1998. Perspectives Service on Devolution, APA Journal AUTUMN.

HG. Surie, 1987. Ilmu Administrasi Negara: Suatu Bacaan. Gramedia Pustaka, Jakarta.

Huber, Marcel, 2007. Service Autonomy in Concept and Theory. Published by American Press, USA.

Huckman, Morgan, 2008. Organization Theory, A Macro Perspective for management, Prentice-Hall, New York.

Harrison, William, 2008. Service Transaction Cost in Government, dalam Journal Bureucracy, Vol. 4(3), 2008: 12-16

Herlind, Harold, 2006. Power and Society of Public Administration. Singapore: Singapore Press Holding

Ilham, Thamrin, 2005. Keadilan yang Merata dan Tanpa Diskriminan dalam Pelayanan Organisasi Kerja. Penerbit Pustakajaya, Jakarta.

Jabra, J.G. and Dwivedi, O.P., 1989. Public Service Accountability Connected. Kumarin Press Inc, New York.

Jessy, Corazon, 2008. Added Value in Government Bureacracy Cost Service, dalam Journal State Budget, Vol. 2(1), 2008: 8-9

Karel, Lann, 2006. Theories of Organizations: Form, Process and Transformation in Empowerment of Community. A Wiley International Publ., New York.

Kats, M. Saul and Rozenweig, 1982. Modernisasi Administrasi untuk Pembangunan Nasional: Suatu Arahan Praktis. Penerbit Bina Aksara, Jakarta. 
Keban, Y.T., 2004. Dimensi Strategis Administrasi Publik. Rajawali Press, Jakarta.

Keputusan Menteri Negara Pendayagunaan Aparatur Negara Nomor 81 Tahun 1993 tentang Pedoman Tatalaksana Pelayanan Umum

Klein, Howard J. and Jay S. Kim, 2000. A Field Study of the Influence of Situational Constraints, Leader-Member Exchange, and Goal Commitment on Performance: Academy of Management Journal, Vol. 41, No. 1 (85-95).

Kristiadi, JB, 1994. Administrasi Manajemen Pembangunan. Penerbit LAN, Jakarta.

Lamdant, WG. Guci, 2007. Network Service Management, John Wiley and Sons, California.

Leonardo, Macraully, 2008. Organization Theory in Public Administration. New York, John Wiley and Sons

Mahadarma. 2012. Asimetrik-informasi-HAM-kebebasan-berpendapat-bagi-kelompokmarjinal. http://mahadarmaworld.wordpress.com. Diakses 25 Januari 2013

Marasabessy A. Z. 2011. Analisis Biaya Transaksi (Transaction Cost) Pengelolaan sumberdaya perikanan (Studi Kasus: Kecamatan Leihitu). Kabupaten Maluku Tengah

Marcel, Davidson, 2003. Service Quality in Concept and Theory. Published by American Press, New York.

Matthews, Jorgy, 2005. The Structure of Unstructured Decision Processed. Prentice Hall, Ohio University.

Moenir. 2003. Manajemen Pelayanan Umum di Indonesia, Gunung Agung, Jakarta.

Murdock, James P., 2005. Public Policy: An Evolution Administration Approach. Belmont: Wadswort.

Nasution. S. 1992. Metodologi Penelitian Naturalistik Kualitatif, CV. Tarsito, Bandung

Natsir, Muh., 2004. Penerapan Sistem Pelayanan Minimal. Penerbit Aditya Buana Ilmu, Bandung.

Nearly, Jeremy, 2003. Economic Transaction of Development: Empirical Investigation of Farm. Hasper and Row

Norman, Davis, 2004. Service Management System. Prentice Hall Ohio University Press, USA.

Nurdin, Djalil, 2003. Pentingnya Ketepatan Waktu dalam Pelayanan Prima. Penerbit Harvarindo, Jakarta.

Osborne, David Plastrik and Peter. 1997. Memangkas Birokrasi. Penerbit PPM, Jakarta. 
Osborne, David dan Gaebler, Ted. 2000. Mewirausahakan Birokrasi. Penerbit PPM, Jakarta.

Padje, dkk. 2006. Kinerja Birokrasi Pelayanan Publik. http://id.wikipedia.org/wiki/pelayananpublik. Akses tanggal 1 Oktober 2009.

Parasuraman, A. Valerie, 2001. Delivering Quality Service. (Diterjemahkan oleh Sutanto).The Free Press, New York.

Pasolong, H. 2007. Teori Administrasi Publik. Cetakan Pertama. Penerbit Alfabeta, Bandung.

Pesch, James, 2005. Implementation of Service Administration Public. London: Sage

Peraturan Gubernur Maluku Nomor 56 Tahun 2009 tentang uraian tugas Sekretariat Daerah Provinsi Maluku

Peraturan Presiden Republik Indonesia, Nomor 54 Tahun 2010 Tentang Pengadaan Barang/Jasa Pemerintah

Peter, J.H., 2003. Service Management in Managing The Image. Trisakti University, Jakarta.

Pusat Jaminan Mutu. 2012. Manual Prosedur Pengadaan Barang/Jasa dan Pemeliharaan Aset. Universitas Brawijaya, Malang

Rakhmat, 2009. Teori Administrasi dan Manajemen Publik. Penerbit Pustaka Arief, Tangerang-Banten.

Rangkuti, Freddy, 2004. Konsep Pengukuran Kepuasan Pasien. Penerbit PT. Gramedia Pustaka Utama, Jakarta.

Ritzer, George, Gullbart, Michael, 2005. Development of Organization Management. Englewood Cliffs: N.J: Prentice Hall

Rivai, Veithzal, 2005. Kiat Kepemimpinan Administrasi di Abad 21. Penerbit Murai Kencana, Jakarta.

Rizal, Syamsurya, 2004. Transparansi Pelayanan dan Standar Pelayanan Minimal. Penerbit Salemba Empat, Jakarta.

Robert H, 2000. Public Administration: Understanding Management. Published McGraw Hill, New York.

Roberts, Edward B, 2002, Innovation - Driving Product, Process and Market Change, MIT, Cambridge

Rondinelli, Dennis A. 1981. Decentralization in Developing Countries : A Review of Recent Experience. World Bank Staff Working Papers. Washington DC. 
Ruiter, Milton, 2008. The Element of Administration Development, Ithaca: Cornell University Press.

Salim, Agus, 2001. Bangunan teori: Metodologi penelitian untuk bidang sosial, psikologi dan pendidika. Edisi Kedua. Yogyakarta: Tiara Wacana

Samuelson, Jeniston, 2000. Application of Quality Service Theory. Published by John Wiley and Sons, USA.

Santosa, Pandji, 2008. Administrasi Publik. Teori dan Aplikasi Good Governance. Cetakan Pertama. Penerbit PT. Refika Aditama, Bandung.

Sasongko, Hermanto, 2006. Pengantar Analisis Kebijakan Publik. (Penyunting: Darwin Muhadjir). Yogyakarta: Gajah Mada University Press.

Sastrohadiwiryo, B. Siswanto. 2003. Manajemen Tenaga Kerja Indonesia Pendekatan Administratif dan Operasional. Jakarta: Bumi Aksara

Setiyono, 2005. Perilaku Administrasi dalam Pelayanan Publik. Penerbit Bumi Aksara, Jakarta.

Shah, Haryono, 1987. Patologi Administrasi Publik dan Birokrasi. Penerbit Rineka Cipta, Jakarta.

Siagian, P. Sondang, 1995. Manajemen Sumber Daya Manusia. Penerbit Bumi Aksara, Jakarta.

Siagian, P. Sondang, 2004. Filsafat Administrasi. Penerbit Bumi Aksara, Jakarta.

Silalahi, Ulbert, 1999. Studi tentang Administrasi: Konsep, Teori dan Dimensi. Penerbit Sinar Baru Algensindo, Bandung.

Hart, Silberd, 2007. Transaction Cost as Barometer Measure of Service Quality in Georgia Regional America, dalam Journal Diplomat, Vol. 2(1), 2007: 1-2

Simon, S. 1999. Memahami Good Governance dalam Perspektif Pelayanan. Penerbit Gava Media, Jakarta.

Sinambela, Soemandar, 2005. Pengantar IImu Pemerintahan, Penerbit Fakultas IImu Sosial Dan Ilmu Politik Universitas Diponegoro, Semarang.

Spears, Larry, 2004. Identification of Service Quality in Public Service Management. http://id.wikipedia.org/wiki/pelayananpublik. Akses tanggal 1 Oktober 2009.

Stemma, Patrick, 2007. Transaction Theory in Organization Environment. State University of New York Press, Albany

Steenge, Jerry, 2008. The Activity of Government Bureacracy. Published by Sage Production, USA 
Stephen, Robbert, 2005. The Concept and Theory of Cost. Englewood Cliffs, Prentice Hall, New Jersey.

Stemvelt, Robert C., 2004. Perception of Service Quality. (Diterjemahkan oleh Purwoko). Allyn and Bacon, Massachusetts.

Supriyono. 2000. Akuntansi Biaya, Buku 1, edisi dua. BPFE, Yogyakarta

Syafiie, Inu Kencana. 1999. Ilmu Administrasi Publik. Jakarta: Rineka Cipta.

Teulings, Marshall, 2003. The Reformation of Administration Bureacracy System. Published by Thompson Learning Press, USA

Thaler, Hudson, 2003. Comparison of Administration Theories. Journal of Public Administration, Vol. 45 No. 4.

Tietz, 2002. Development Management and Planning. Publishing by Economic Cooperation and Development.

Tjiptono, Fandy, 2003. Kepuasan Pasien dalam Pelayanan. Penerbit Salemba Empat, Jakarta

Tjokroamidjojo, Bintoro, 2004. Pengantar Administrasi Pembangunan. Penerbit Haji Mas Agung, Jakarta.

Tood, Lebey, 2005. Analysis and Approach of Strategy. Manchester University Press, Manchester

Viscusi, WK, 2003. The Planning and Development Public Policy, New York, Oxford University Press.

Waarden, Van Burd, 2006. Bureacracy Administration: Theory and Practice. Published by John Wiley and Sons, California

Waldo, Widodo, 1991. Manajemen Administrasi: Suatu Pengantar. Penerbit Bayumedia Publishing, Jakarta.

Walters, D, 1994. The Administration and Problem Scope. New York: Free Press.

Webley, P. 2005. The Impact of Policy Public. Edward Elgar Published, New Jersey.

Westra, Wasistiono, 1999. Menata Ulang Kelembagaan Pemerintah Kecamatan, Citra Pindo, Bandung.

Wibisono, Agus. 2010. Efektif dan Efisien. http://aguswibisono.com/2010/efektif-danefisien/. Diakses 20 Januari 2013

Williamson, Olivier E. 1996. The Modern Corporation: Origins, Evolution, Attributes. Journal of Economic Literature 19: 1537-568.

Winardi, J., 2004. Administrasi dan Management Organisasi. Penerbit Kencana Prenada Media, Jakarta. 
Wittman, DA, 2004. Application of Public Service in Good Governance. Published by John Wiley and Sons, New York.

Yates, Crozier, 2001. The Administration Phenomenon. London: Tavistock

Yoga, Nyoman, 2003. Aktivitas Pelayanan yang Berkualitas. Penerbit Rajawali Press, Jakarta.

Yong, C.Z., Yun, Y.W., Loh, L. 2003. The Quest for Global Quality. (Diterjemahkan oleh Sutanto). Pustaka Delapratasa, Jakarta.

Zauhar, Mansyur, 1999. Teori-teori Mutakhir Administrasi Publik. Penerbit Rangkang Education, Yog

Zeithaml, et. al. 1990. Delivering Quality Service. (Diterjemahkan oleh Sutanto).The Free Press, New York.

Zulkifli, Anwar, 2002. Efisiensi Waktu dalam Kinerja Pelayanan. Penerbit Eka Persada Ilmu, Jakarta. 



\section{Riwayat Hidup}

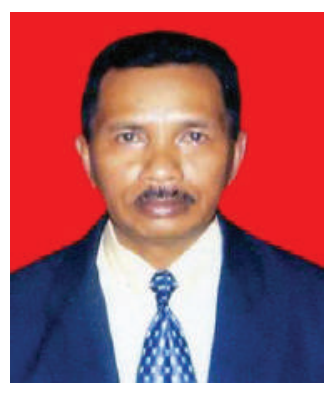

Dr. Samson Laurens, MT,M.Si., adalah doktor bidang administrasi publik, lahir di Ambon, 27 Januari 1956. Tahun 1985-2011, penulis merupakan Pegawai Negeri Sipil pada Dinas Perindustrian dan Perdagangan Provinsi Maluku. Tahun 2004-2011, penulis merupakan Widyaiswara pada Badan Pendidikan dan Pelatihan Provinsi Maluku.Saat ini, penulis merupakan Dosen Negeri DPK pada Fakultas Ilmu Sosial dan Ilmu Politik Universitas Kristen Indonesia Maluku Ambon dengan pangkat Lektor Kepala.

Penulis memiliki banyak pengalaman menulis pada publikasi ilmiah nasional maupun internasional. Penulis aktif mengikuti kegiatan pelatihan, baik yang lokal, regional maupun nasional. Penulis juga memiliki pengalaman mengajar di beberapa perguruan tinggi di Ambon yakni di Akademi Maritim Maluku dan STIA Trinitas Ambon serta pada Program Studi Administrasi Publik Pascasarjana Universitas Pattimura Ambon. Buku ini merupakan buku pertama yang diterbitkan oleh Penerbit Pensil Komunika Yogyakarta. 



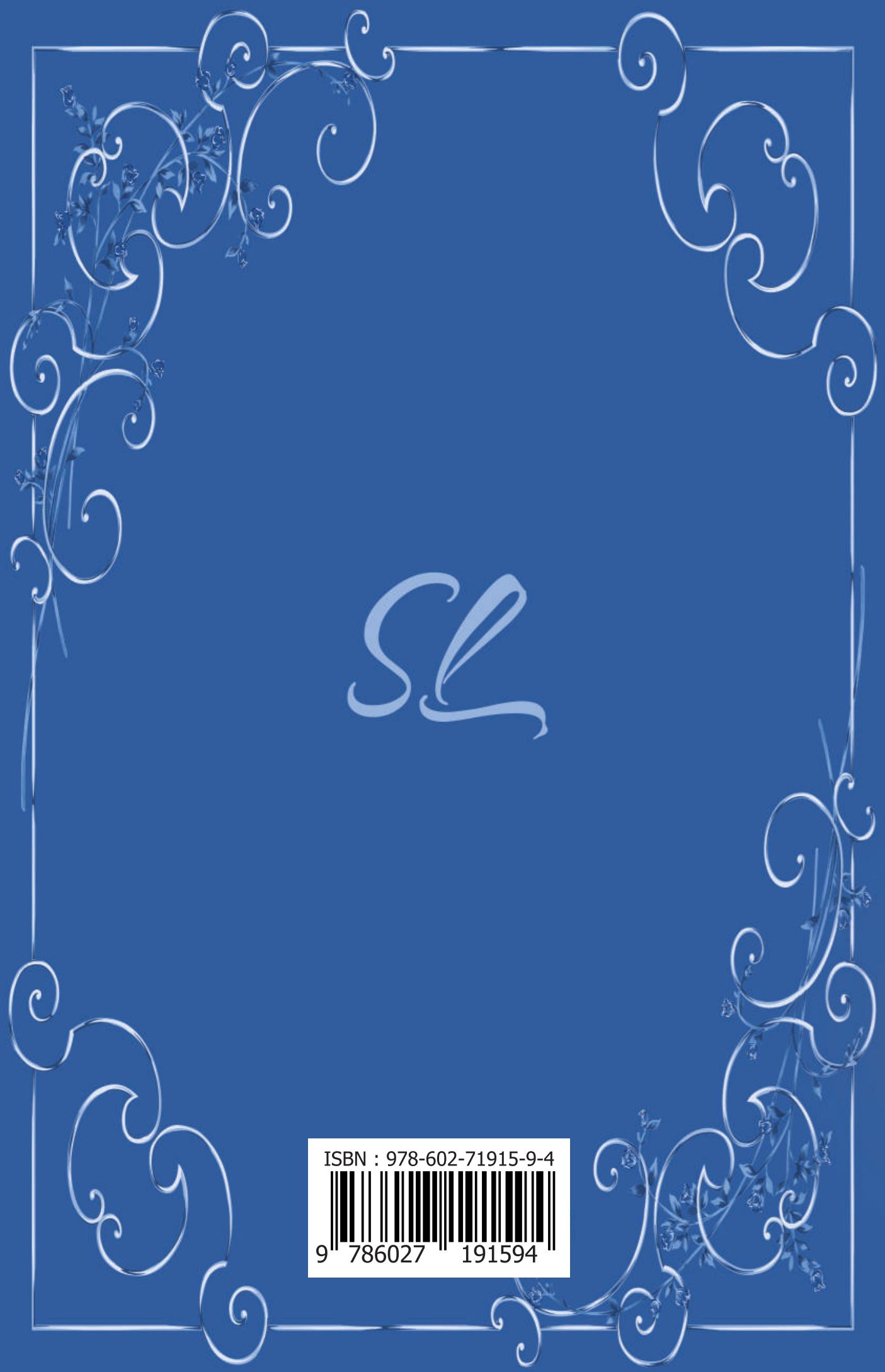

